Florida International University FIU Digital Commons

3-20-2015

\title{
Overweight/Obesity and HIV Disease Progression in HIV+ Adults in Botswana
}

Sabrina Sales Martinez

Florida International University, saless@fiu.edu

DOI: $10.25148 /$ etd.FI15032168

Follow this and additional works at: https://digitalcommons.fiu.edu/etd

Part of the Immunology of Infectious Disease Commons, and the Nutrition Commons

\section{Recommended Citation}

Martinez, Sabrina Sales, "Overweight/Obesity and HIV Disease Progression in HIV+ Adults in Botswana" (2015). FIU Electronic Theses and Dissertations. 1826.

https://digitalcommons.fiu.edu/etd/1826

This work is brought to you for free and open access by the University Graduate School at FIU Digital Commons. It has been accepted for inclusion in FIU Electronic Theses and Dissertations by an authorized administrator of FIU Digital Commons. For more information, please contact dcc@fiu.edu. 


\title{
FLORIDA INTERNATIONAL UNIVERSITY
}

\author{
Miami, Florida
}

\section{OVERWEIGHT/OBESITY AND HIV DISEASE PROGRESSION IN HIV+ ADULTS IN BOTSWANA}

\author{
A dissertation submitted in partial fulfillment of \\ the requirements for the degree of \\ DOCTOR OF PHILOSOPHY \\ in \\ DIETETICS AND NUTRITON \\ by
}

Sabrina Sales Martinez 
To: Interim Dean Mark Williams

R.Stempel College of Public Health and Social Work

This dissertation, written by Sabrina Sales Martinez, and entitled Overweight/Obesity and HIV Disease Progression in HIV+ Adults in Botswana, having been approved in respect to style and intellectual content, is referred to you for judgment.

We have read this dissertation and recommend that it be approved.

Marianna K. Baum

Fatma G. Huffman

O. Dale Williams

Adriana Campa, Major Professor

Date of Defense: March 20, 2015

The dissertation of Sabrina Sales Martinez is approved.

Interim Dean Mark Williams

R.Stempel College of Public Health and Social Work

Dean Lakshmi N. Reddi

University Graduate School

Florida International University, 2015 


\section{DEDICATION}

First and foremost, I thank my parents for their love and support throughout my life and during my journey in completing my doctoral degree. To my loving husband, many thanks for supporting me in any outrageous endeavor I have ever wanted to embark on, including a PhD.

I also dedicate this dissertation to my uncle and godfather who passed away too young from HIV and was not able to live to see and take advantage of the progress and wonderful discoveries made in HIV research. His memory will always drive my passion for research in this field. 


\section{ACKNOWLEDGMENTS}

This dissertation would not have been possible without the assistance, support, guidance and efforts of my committee members. I am very grateful to Dr. Campa, my Major Professor extraordinaire, who has guided me through the entire process and never let me give up. I will never forget all the time and effort you invested in making sure I succeeded. Dr. Baum, thank you for providing me with all the wonderful research opportunities to learn so many skills that were not only valuable for my dissertation but also for my career. I am indebted to both of you, Dr. Baum and Dr. Campa, for allowing me to have access to your research resources for my dissertation. You have provided me with great examples of successful and hardworking researchers, who also happen to be incredibly gracious women. Dr. Huffman, thank you for always having an open-door policy and providing me with great advice and guidance throughout my doctoral degree. Thank you Dr. Williams for your time and statistical expertise. I would also like to acknowledge Dr. Mehmet Dorak for his help with the genotyping portion of my dissertation and providing me with access to your laboratory resources. Thank you Dr. Dorak for always taking the extra time to help and guide me.

Finally, I would like to acknowledge the Minority Biomedical Research Support (MBRS) RISE Biomedical Research Initiative (BRI) Research Award, CDR Diversity Scholarship provided by the Academy of Nutrition and Dietetics and Adolfo Henriquez Scholarship for providing funding to complete the laboratory analyses for my dissertation. 


\section{ABSTRACT OF THE DISSERTATION}

\section{OVERWEIGHT/OBESITY AND HIV DISEASE PROGRESSION IN HIV+ ADULTS IN}

\section{BOTSWANA}

by

\section{Sabrina Sales Martinez}

Florida International University, 2015

Miami, Florida

\section{Professor Adriana Campa, Major Professor}

Studies indicate that overweight and obesity protect against HIV-disease progression in antiretroviral therapy (ART)-naïve patients. We examined retrospectively the relationship of overweight/obesity with HIV-disease progression in ART-naïve HIV+ adults in Botswana in a case-control study with 18-month follow-up, which included 217 participants, 139 with BMI 18.0-24.9 kg/m² and 78 with BMI $\geq 25 \mathrm{~kg} / \mathrm{m}^{2}$. Archived plasma samples were used to determine inflammatory markers: leptin and bacterial endotoxin lipopolysaccharide (LPS), and genotype single nucleotide polymorphisms (SNPs) of the Fat Mass and Obesity Associated Gene (FTO).

At baseline, BMI was inversely associated with risk for AIDS-defining conditions $(\mathrm{HR}=0.218 ; 95 \% \mathrm{Cl}=0.068,0.701, P=0.011)$, and higher fat mass was associated with reduced risk of the combined outcome of CD4+cell count $\leq 250 / \mu \mathrm{L}$ and AIDS-defining conditions, whichever occurred earlier $(\mathrm{HR}=0.918 ; 95 \% \mathrm{Cl}=0.847,0.994, P=0.036)$ over 18 months, adjusting for age, gender, marriage, children, and baseline CD4+cell count and HIV-viral load.

FTO-SNP rs17817449 was associated with $\mathrm{BMI}(\mathrm{OR}=1.082 ; 95 \% \mathrm{Cl}=1.001$, 1.169; $P=0.047)$. Fat mass was associated with the risk alleles of $r s 1121980(O R=1.065$; $95 \% \mathrm{Cl}=1.009,1.125, P=0.021), \mathrm{rs} 8050136(\mathrm{OR}=1.078 ; 95 \% \mathrm{Cl}=1.021,1.140 ; P=0.007)$, 
and $\mathrm{rs} 17817449(\mathrm{OR}=1.086 ; 95 \% \mathrm{Cl}=1.031,1.145 ; P=0.002)$, controlling for age, gender, tribe, total energy intake, and activity. There were no associations of SNPs with markers of disease progression.

Leptin levels were positively associated with $\mathrm{BMI}(\beta=1.764 ; 95 \% \mathrm{Cl}=0.788,2.739$; $P=0.022)$ and fat mass $(\beta=0.112 ; 95 \% \mathrm{Cl}=0.090,0.135 ; P<0.001)$, but inversely with viral load $(\beta=-0.305 ; 95 \% \mathrm{Cl}=-0.579,-.031 ; P=0.030)$. LPS levels were inversely associated with $\mathrm{BMI}(\mathrm{OR}=0.790,95 \% \mathrm{Cl}=0.630,0.990 ; P=0.041)$, and fat mass $(\mathrm{OR}=0.852$, $95 \% \mathrm{Cl}=0.757,0.958 ; P=0.007)$ and directly with viral load $(\mathrm{OR}=2.608,95 \% \mathrm{Cl}=1.111$, 6.124; $P=0.028)$, adjusting for age, gender, smoking and \%fat mass.

In this cohort, overweight/obesity predicted slower HIV-disease progression. Obesity may confer an advantage in maintaining fat stores to support the overactive immune system. FTO-SNPs may contribute to the variation in fat mass; however, they were not associated with HIV-disease progression. Our findings suggest that the obesity paradox may be explained by the association of increased LPS with lower BMI and higher viral load; while viral load decreased with increasing leptin levels. Studies in African populations are needed to clarify whether genetic variation and inflammation mediate the obesity paradox in HIV-disease progression. 


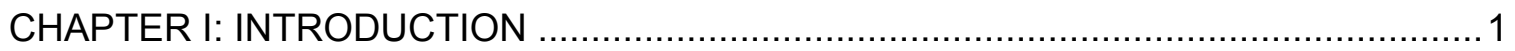

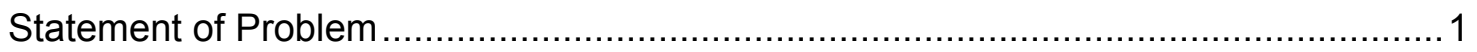

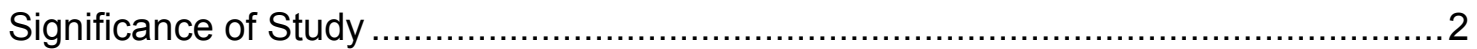

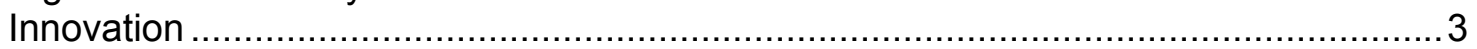

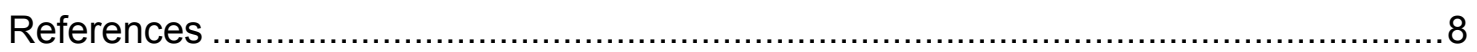

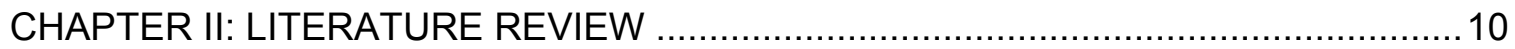

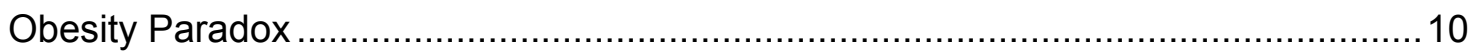

Potential Mechanisms for the Obesity Paradox................................................ 11

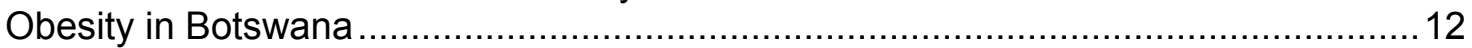

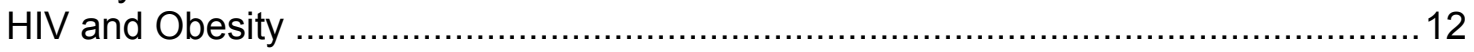

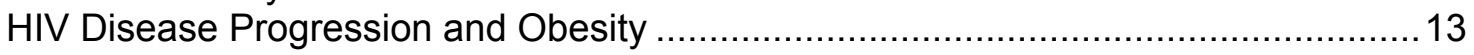

HIV Disease Progression and Body Composition ............................................. 16

The Fat Mass and Obesity Associated (FTO) Gene in African Populations .................17

The Fat Mass and Obesity Associated (FTO) Gene and HIV Disease Progression ...19

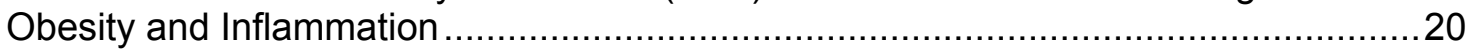

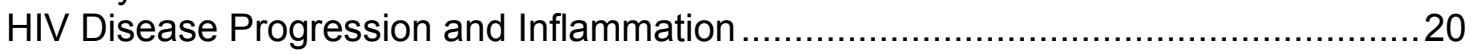

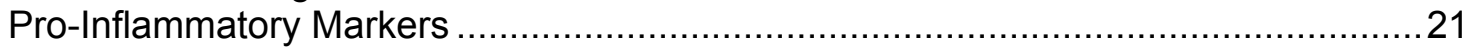

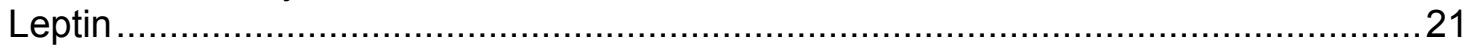

HIV Disease Progression and Leptin in HIV ART Naïve .......................................23

The Fat Mass and Obesity Associated (FTO) Gene and Leptin ..............................25

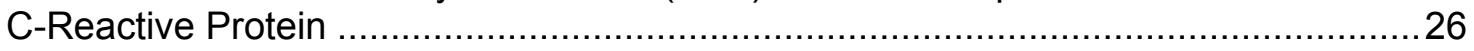

HIV Disease Progression and C-Reactive Protein in HIV ART Naïve .......................27

The Fat Mass and Obesity Associated (FTO) Gene, and CRP ..............................29

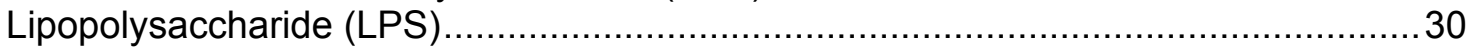

HIV Disease Progression and Lipopolyssacharide (LPS) in HIV ART Naïve ...............31

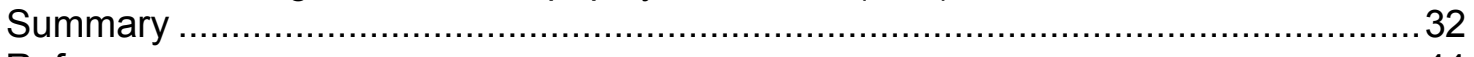

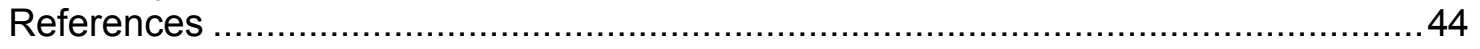

CHAPTER III: EFFECT OF BMI AND BODY COMPOSITION ON HIV DISEASE PROGRESSION IN HIV INFECTED ART NAÏVE ADULTS IN BOTSWANA ................53

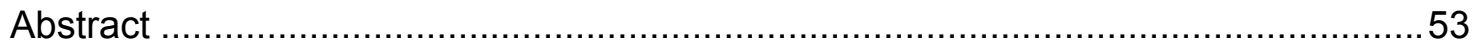

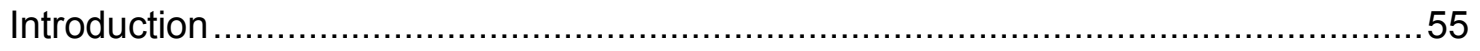

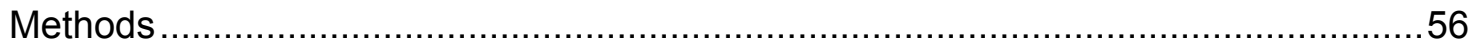

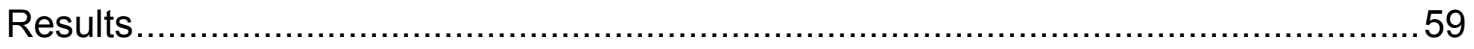

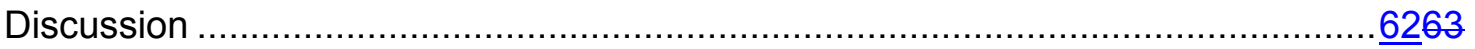

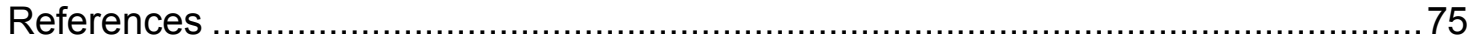

CHAPTER IV: PRELIMINARY ASSOCIATION STUDY OF THE FAT MASS AND

OBESITY ASSOCIATED GENE POLYMORPHISMS WITH HIV DISEASE

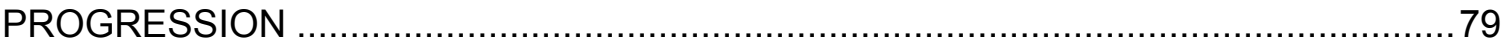

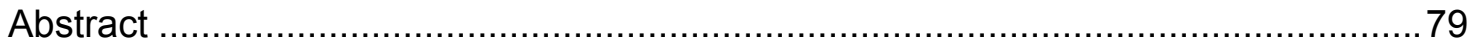

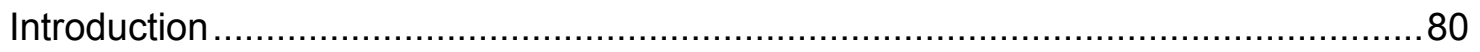

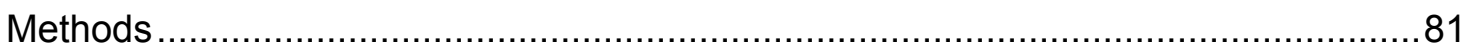

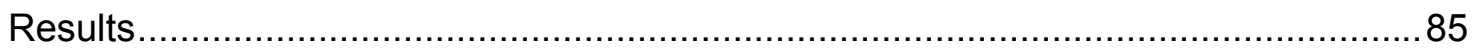

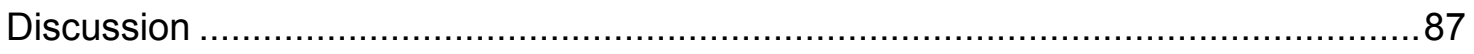




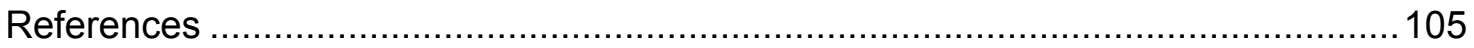

CHAPTER V: ASSOCIATION OF INFLAMMATORY MARKERS WITH HIV DISEASE

PROGRESSION IN ART NAÏVE HIV+ ADULTS IN BOTSWANA ............................109

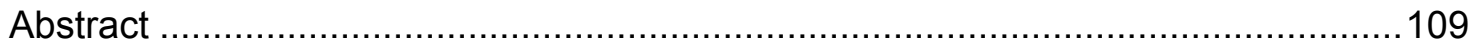

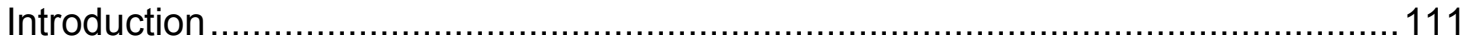

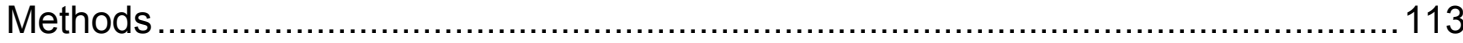

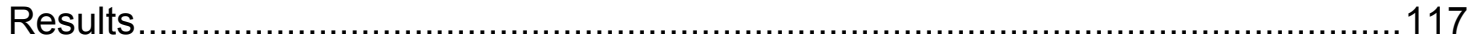

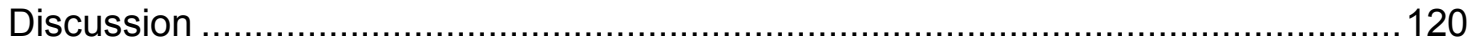

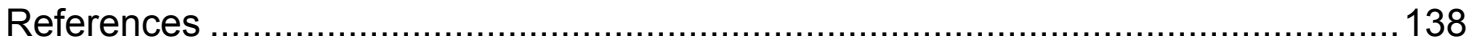

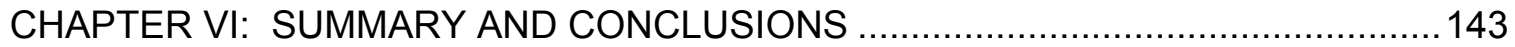

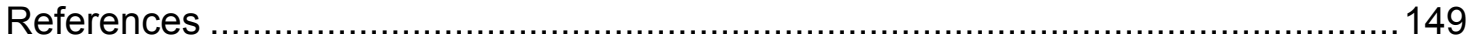

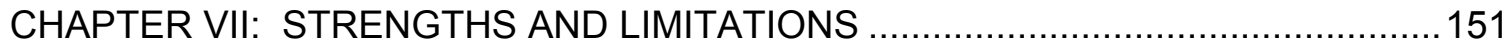

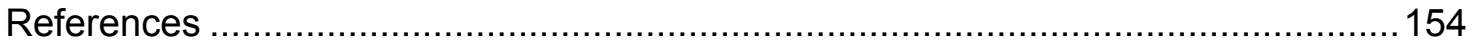

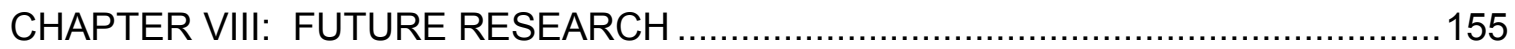

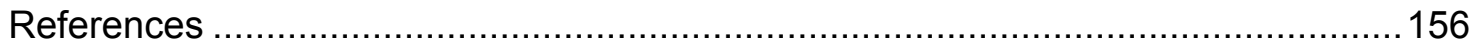

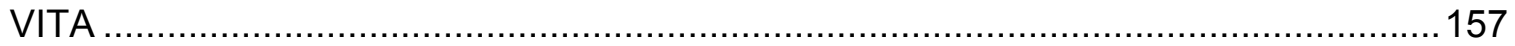




\section{LIST OF TABLES}

TABLE

PAGE

CHAPTER I

Table 1: Statistical Analysis of Hypotheses

CHAPTER II

Table 1: Studies Conducted in Obesity and HIV Disease Progression

Table 2: Genetic Association Studies on the FTO Gene in African Populations .............. 37

Table 3: Studies Conducted on Leptin and HIV Disease Progression in ART Naïve...... 39

Table 4: Studies Conducted on C-Reactive Protein and HIV Disease Progression in

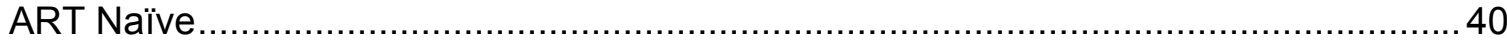

Table 5: Studies Conducted on LPS and HIV Disease Progression in ART Naïve......... 42

CHAPTER III

Table 1: Change in BMI from Baseline to 18 Months by BMI Groups

Table 2: Demographic Characteristics by BMI Group at Baseline

Table 3: Nutrition Related Characteristics by BMI Group at Baseline ...........................70

Table 4: Spearman Correlation Coefficients at Baseline ........................................... 71

Table 5: Logistic Regression at Baseline, 18 Months and the Change Over 18 Months

by BMI Groups

Table 6: Linear Regression at Baseline, 18 Months and the Change Over 18 Months

by Continuous BMI

Table 7: Adjusted Hazard Ratios on the Effect of BMI Groups on HIV Disease

Progression Outcomes in HIV+ Adults in Botswana During a Follow-up Period of 18

Months

Table 8: Adjusted Hazard Ratios on the Effect of Baseline BMI on HIV Disease

Progression Outcomes in HIV+ Adults in Botswana During a Follow-up Period of 18

Months

Table 9: Adjusted Hazard Ratios on the Effect of Baseline Fat Mass on HIV Disease

Progression Outcomes in HIV+ Adults in Botswana During a Follow-up Period of 18

Months

Table 10: Adjusted Hazard Ratios on the Effect of Baseline Lean Mass on HIV

Disease Progression Outcomes in HIV+ Adults in Botswana During a Follow-up

Period of 18 Months

CHAPTER IV

Table 1: FTO SNP Allele and Genotype Frequencies in HIV+ adults in Botswana ........91

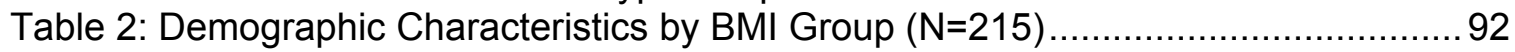

Table 3: FTO rs1121980: Association with Body Composition and Measures of HIV

Disease Progression....

Table 4: FTO rs8050136: Association with Body Composition and Measures of HIV

Disease Progression

Table 5: FTO rs9939609: Association with BMI, Body Composition and Measures of

HIV Disease Progression

Table 6: FTO rs17817449: Association with Body Composition and Measures of HIV

Disease Progression 
Table 7: Association of FTO rs1121980 with Body Composition and HIV disease Progression in a Dominant Model .....

Table 8: Association of FTO rs8050136 with Body Composition and HIV disease

Progression in a Dominant Model 98

Table 9: Association of FTO rs9939609 with Body Composition and HIV disease

Progression in a Dominant Model. 99

Table 10: Association of FTO rs17817449 with Body Composition and HIV disease

Progression in a Dominant Model 100

Table 11: Adjusted Hazard Ratios on the Effect of rs1121980 Using the Dominant Model on HIV Disease Progression Outcomes in HIV+ Adults in Botswana During a Follow-up Period of 18 Months 101

Table 12: Adjusted Hazard Ratios on the Effect of rs8050136 Using the Dominant Model on HIV Disease Progression Outcomes in HIV+ Adults in Botswana During a Follow-up Period of 18 Months .... 102

Table 13: Adjusted Hazard Ratios on the Effect of rs9939609 Using the Dominant Model on HIV Disease Progression Outcomes in HIV+ Adults in Botswana During a Follow-up Period of 18 Months

Table 14: Adjusted Hazard Ratios on the Effect of rs17817449 Using the Dominant Model on HIV Disease Progression Outcomes in HIV+ Adults in Botswana During a Follow-up Period of 18 Months

\section{CHAPTER V}

Table 1: General Characteristics of the Sample Population.

Table 2: Baseline Spearman Correlation Coefficients and $P$-values

Table 3: Relationship Between BMI Groups and Measures of Inflammatory Markers at Baseline

Table 4: Relationship Between CRP Groups and Body Composition and Measures of Inflammatory Markers at Baseline.

Table 5: Relationship Between Median Groups of Leptin and Body Composition and Measures of Inflammatory Markers at Baseline

Table 6: Relationship Between Median Groups of LPS and Body Composition and Measures of Inflammatory Markers at Baseline....

Table 7: Linear Regression at Baseline, 18 Months and the Change Over 18 Months by CRP.

Table 8: Linear Regression at Baseline, 18 Month, and the Change Over 18 Months

by Leptin.

Table 9: Linear Regression at Baseline, 18 Months, and the Change Over 18 Months

by LPS

Table 10: Logistic Regression at Baseline, 18 Months, and the Change Over 18 Months by CRP Groups (< and $\geq 3 \mathrm{mg} / \mathrm{L}$ )

Table 11: Logistic Regression at Baseline, 18 Months, and the Change Over 18 Months by Leptin Groups (< and $\geq$ Median).

Table 12: Logistic Regression at Baseline, 18 Months, and the Change Over 18 Months by LPS Groups (< and $\geq$ Median).

\section{CHAPTER VI}

Table 1: Study Hypotheses and Results 


\section{ABBREVIATIONS AND ACRONYMS}

AIDS

ART

BIA

$\mathrm{BMI}$

CRP

FTO

HALS

HIV

IL-6

$\mathrm{LAL}$

LPS

SNP

TB

TNF- $\alpha$
Acquired Immune Deficiency Syndrome

Antiretroviral Therapy

Bioelectrical impedance

Body mass index

C-reactive protein

Fat mass and obesity associated gene

HIV associated lipodystrophy syndrome

Human Immunodeficiency Virus

Interleukin 6

Limulus amebocyte lysate

Lipopolysaccharide

Single nucleotide polymorphism

Tuberculosis

Tumor necrosis factor alpha 


\section{CHAPTER I: INTRODUCTION}

\section{Statement of Problem}

The prevalence of obesity is increasing worldwide, including developing African nations. ${ }^{1,2}$ Botswana is experiencing an increase in obesity, which is also observed among the HIV+ adults. ${ }^{3}$ At the same time, Botswana is experiencing one of the worst epidemics of HIV with a prevalence rate of $23.0 \%$ among those between the ages 15 to 49 years. ${ }^{4}$ An obesity paradox has been documented in many conditions including HIV, where those who are obese may have a survival advantage or improved disease outcomes. ${ }^{5}$ It is described as paradox in HIV since obesity has been associated with higher CD4 cell counts and delayed time to AIDS defining conditions. ${ }^{6-9}$ Studies on HIV and obesity are mainly conducted in settings where the patients are treated with antiretroviral therapy (ART), and where being or becoming obese is a disadvantage for physical and mental reasons, as obesity increases the risk for comorbidities with

confounding findings and interpretations. ${ }^{10,11}$ In addition, inflammation accompanies both obesity and HIV disease, and its role in HIV disease progression has not been described in the ART naïve population, specifically as related to markers of inflammation such as Leptin, C-reactive protein and immune activation and bacterial lipopolysaccharide (LPS) endotoxin.

Genetics has a strong influence on obesity ${ }^{12}$ which has been estimated to account for $40-70 \%$ of the variation in human adiposity. ${ }^{13}$ The association of the Fat Mass and Obesity Associated (FTO) gene has been reported to be strong with obesity, however, it has not been replicated in all populations and currently there are no published studies on the FTO gene variants in HIV disease or in a population in Botswana. 
The objective of this study was to examine the relationship between overweight/obesity and HIV disease progression, inflammatory markers, and SNPs of the FTO gene in HIV+ adults who are not on ART in Botswana.

\section{Significance of Study}

The proposed research is important since there are several studies in the literature indicating that overweight or obesity provides some protection from accelerated HIV disease progression, ${ }^{6-9}$ but the potential mechanisms for such relationships are lacking. This study design allows for the examination of the effects of HIV before ART initiation to obtain a better understanding of how obesity and genetic factors are interrelated and affect HIV disease progression. In addition, as HIV becomes a chronic disease with the advent of more effective and accessible treatments, and the risks for obesity and its comorbidities increase, recognizing genetic susceptibility for obesity will help design interventions that are tailored to an individual's genetic variations. ${ }^{14}$

The evidence from the literature generates the following questions:

- Is the "obesity advantage" related to the genetically acquired energy efficiency, regardless of fat accumulation, or it is associated with fat accumulation that provides a protection to rapid wasting, which is one of the most powerful signs of HIV-disease progression and associated with shorter time to death?

- Could it be the result of both factors?

- How does the interaction of obesity and HIV affect inflammation and the immune response?

- Could those without a genetic risk for obesity benefit from early aggressive nutrition intervention and ART to prevent wasting? 
Botswana is one of the first resource-limited countries to provide ART on a sizeable scale ${ }^{15}$ however, many countries, especially in sub-Saharan Africa, still have challenges in providing ART and maintaining adherence. ${ }^{16}$ Of the 21.2 million people in Africa eligible for ART under the 2013 WHO guidelines, only 7.6 million are receiving ART. ${ }^{17}$ Therefore, acquiring information on factors that may delay disease progression and possible mechanisms related to these risks is significant and timely. Moreover, the findings from this study could be translated and contribute towards clinically relevant recommendations.

\section{Innovation}

This is the first study exploring the role of genetic susceptibility to obesity as a positive factor to delay HIV disease progression in ART naïve patients.

In the following three studies, hypotheses were tested and results presented as research papers.

\section{Specific Aims and Hypothesis}

\section{CHAPTER III: EFFECT OF BMI AND BODY COMPOSITION ON HIV DISEASE PROGRESSION IN HIV INFECTED ART NAÏVE ADULTS IN BOTSWANA}

Specific Aim 1: To determine the relationship between being overweight/obese (BMI $\geq$ $25 \mathrm{~kg} / \mathrm{m}^{2}$ ) and HIV disease progression (CD4 cell count, HIV viral load and AIDS defining conditions) in HIV+ asymptomatic adults in Botswana not on antiretroviral therapy (ART) over 18 months.

Hypothesis 1a: (Primary outcome) The overweight/obese group will present less clinically significant CD4 cell count decline from Baseline $(\geq 25 \%)$ over 18 months than the normal weight group.

Hypothesis 1b: The overweight/obese will have significantly lower levels of HIV viral load over 18 months than the normal weight group.

Hypothesis 1c: Significantly less AIDS defining conditions will occur over 18 months in the overweight/obese group compared to the normal weight group. 


\section{CHAPTER IV: PRELIMINARY ASSOCIATION STUDY OF THE FAT MASS AND OBESITY GENE POLYMORPHISMS WITH HIV DISEASE PROGRESSION}

Specific Aim 2: To determine the interrelationships among being overweight/obese, markers of genetic propensity for obesity (single nucleotide polymorphisms (SNPs) in FTO) and HIV disease progression (CD4 cell count, HIV viral load and AIDS defining conditions) in HIV+ asymptomatic adults in Botswana not on ART over 18 months.

Hypothesis 2a: The FTO gene SNPs will be associated with being overweight/obese.

Hypothesis 2b: The FTO gene SNPs will be associated with delayed HIV disease progression over 18 months.

Hypothesis 2b1: The FTO gene SNPs will be associated with significantly higher CD4 cell count.

Hypothesis 2b2: The FTO gene SNPs will be associated with significantly lower HIV viral load.

Hypothesis 2b3: The FTO gene SNPs will be associated with significantly less AIDS-defining conditions.

\section{CHAPTER V: ASSOCIATION OF INFLAMMATORY MARKERS WITH BODY COMPOSITION AND HIV DISEASE PROGRESSION IN ART NAÏVE HIV+ ADULTS IN BOTSWANA}

Specific Aim 3: To evaluate the relationship between the inflammatory markers (leptin, C-reactive protein and bacterial lipopolysaccharide) and HIV disease progression in HIV+ asymptomatic adults not on ART in Botswana over 18 months.

Hypothesis 3a: Higher levels of leptin, C-reactive protein and bacterial lipopolysaccharide will be associated with significantly faster HIV disease progression.

Hypothesis 3a1: Higher levels of inflammatory markers will be associated with lower levels of CD4 cell count.

Hypothesis 3a2: Higher levels of inflammatory markers will be associated with higher HIV viral load.

Hypothesis 3a3: Higher levels of inflammatory markers will be associated with greater AIDS-defining conditions. 
Table 1: Statistical Analysis of Hypotheses

\begin{tabular}{|c|c|c|c|c|c|c|c|}
\hline Hypothesis & $\begin{array}{l}\text { Dependent } \\
\text { Variable } \\
\text { (Outcome } \\
\text { Variable) }\end{array}$ & $\begin{array}{l}\text { Measurement } \\
\text { of Dependent } \\
\text { Variable }\end{array}$ & $\begin{array}{c}\text { Type of } \\
\text { Dependent } \\
\text { Variable }\end{array}$ & $\begin{array}{c}\text { Independent } \\
\text { Variable }\end{array}$ & $\begin{array}{c}\text { Measurement } \\
\text { of } \\
\text { Independent } \\
\text { Variable }\end{array}$ & $\begin{array}{c}\text { Type of } \\
\text { Independent } \\
\text { Variable }\end{array}$ & Statistical Analysis \\
\hline $1 a$ & $\begin{array}{c}\text { CD4 cell } \\
\text { count } \\
\text { (decrease of } \\
\geq 25 \% \text { ) }\end{array}$ & $\begin{array}{l}\text { CD4 cell count } \\
\text { in blood }\end{array}$ & $\begin{array}{c}\text { Dichotomous } \\
\text { variable }(0=\text { no } \\
\text { decrease } \geq 25 \% \\
\text { and } 1=\text { yes } \\
\text { decrease } \\
\geq 25 \%)\end{array}$ & $\begin{array}{l}\text { Body Mass } \\
\text { Index (BMI) }\end{array}$ & $\begin{array}{l}\text { BMI measured } \\
\text { as weight in } \\
\mathrm{kg} / \text { height in } \\
\text { meters } \\
\text { squared }\end{array}$ & $\begin{array}{c}\text { Dichotomous } \\
\text { variable }(0=\mathrm{BMI} \\
\begin{array}{c}18.0-24.9 \mathrm{~kg} / \mathrm{m}^{2} \\
\text { and } 1=\mathrm{BMI} \geq 25 \\
\left.\mathrm{~kg} / \mathrm{m}^{2}\right)\end{array}\end{array}$ & $\begin{array}{c}\text { Proportional Hazard } \\
\text { Survival Model will be } \\
\text { performed to compare } \\
\text { hazard ratios on time to } \\
\text { event (CD4 cell count } \\
\text { decrease } \geq 25 \% \text { ) over } 18 \\
\text { months. }\end{array}$ \\
\hline $1 b$ & HIV viral load & $\begin{array}{l}\text { HIV viral load in } \\
\text { blood }\end{array}$ & $\begin{array}{c}\text { Continuous } \\
\text { variable }\end{array}$ & $\begin{array}{l}\text { Body Mass } \\
\text { Index (BMI) }\end{array}$ & $\begin{array}{l}\text { BMI measured } \\
\text { as weight in } \\
\mathrm{kg} / \text { height in } \\
\text { meters } \\
\text { squared }\end{array}$ & $\begin{array}{c}\text { Dichotomous } \\
\text { variable }(0=\mathrm{BMI} \\
\begin{array}{c}18.0-24.9 \mathrm{~kg} / \mathrm{m}^{2} \\
\text { and } 1=\mathrm{BMI} \geq 25 \\
\left.\mathrm{~kg} / \mathrm{m}^{2}\right)\end{array}\end{array}$ & $\begin{array}{c}\text { Pearson and Spearman } \\
\text { correlations, as deemed } \\
\text { appropriate and } \\
\text { scatterplots will be } \\
\text { performed to evaluate the } \\
\text { relationship between HIV } \\
\text { viral load and BMI groups } \\
\text { Linear regression will be } \\
\text { used to examine the } \\
\text { relationship between HIV } \\
\text { viral load, at baseline and } \\
18 \text { months, and BMI } \\
\text { groups }\end{array}$ \\
\hline 1c & $\begin{array}{c}\text { AIDS } \\
\text { Defining } \\
\text { Conditions }\end{array}$ & $\begin{array}{c}\text { Presence of } \\
\text { AIDS Defining } \\
\text { Condition } \\
\text { Recorded by } \\
\text { Study Physician }\end{array}$ & $\begin{array}{l}\text { Dichotomous } \\
\text { variable }(0=\text { no } \\
\text { and } 1=\text { yes })\end{array}$ & $\begin{array}{l}\text { Body Mass } \\
\text { Index (BMI) }\end{array}$ & $\begin{array}{l}\text { BMI measured } \\
\text { as weight in } \\
\mathrm{kg} / \text { height in } \\
\text { meters } \\
\text { squared }\end{array}$ & $\begin{array}{c}\text { Dichotomous } \\
\text { variable }(0=\mathrm{BMI} \\
18.0-24.9 \mathrm{~kg} / \mathrm{m}^{2} \\
\text { and } 1=\mathrm{BMI} \geq 25 \\
\left.\mathrm{~kg} / \mathrm{m}^{2}\right)\end{array}$ & $\begin{array}{l}\text { Proportional Hazard } \\
\text { Survival Model will be } \\
\text { performed to compare } \\
\text { hazard ratios on time to } \\
\text { event (AIDS defining } \\
\text { conditions) over } 18 \\
\text { months. }\end{array}$ \\
\hline $2 a$ & $\begin{array}{l}\text { Body Mass } \\
\text { Index (BMI) }\end{array}$ & $\begin{array}{l}\text { BMI measured } \\
\text { as weight in kg/ } \\
\text { height in meters }\end{array}$ & $\begin{array}{c}\text { Dichotomous } \\
\text { variable }(0=\mathrm{BMI} \\
18.0-24.9 \mathrm{~kg} / \mathrm{m}^{2} \\
\text { and } 1=\mathrm{BMI} \geq 25\end{array}$ & $\begin{array}{l}\text { Genotypes } \\
\text { for FTO } \\
\text { SNPs }\end{array}$ & $\begin{array}{c}5 \text { Genotypes } \\
\text { for FTO SNPs } \\
\text { determined by } \\
\text { TaqMan }\end{array}$ & $\begin{array}{l}\text { Dichotomous } \\
\text { variable }(0=\text { non- } \\
\text { risk alleles and }\end{array}$ & $\begin{array}{l}\text { Logistic Regression will } \\
\text { be performed to see the } \\
\text { relationship between FTO } \\
\text { SNPs and BMI groups. }\end{array}$ \\
\hline
\end{tabular}




\begin{tabular}{|c|c|c|c|c|c|c|c|}
\hline & & squared & $\left.\mathrm{kg} / \mathrm{m}^{2}\right)$ & & $\begin{array}{l}\text { Discrimination } \\
\text { Assay }\end{array}$ & 1=risk allele) & $\begin{array}{l}\text { Cox Proportional Hazard } \\
\text { Survival Model will be } \\
\text { performed to compare } \\
\text { hazard ratios on time to } \\
\text { event }\left(\mathrm{BMI} \geq 25 \mathrm{~kg} / \mathrm{m}^{2}\right) \\
\text { over } 18 \text { months. }\end{array}$ \\
\hline $2 \mathrm{~b} 1$ & $\begin{array}{l}\text { CD4 cell } \\
\text { count }\end{array}$ & $\begin{array}{l}\text { CD4 cell count } \\
\text { in blood }\end{array}$ & $\begin{array}{l}\text { Continuous } \\
\text { variable }\end{array}$ & $\begin{array}{l}\text { Genotypes } \\
\text { for FTO } \\
\text { SNPs }\end{array}$ & $\begin{array}{l}5 \text { Genotypes } \\
\text { for FTO SNPs } \\
\text { determined by } \\
\text { TaqMan } \\
\text { Discrimination } \\
\text { Assay }\end{array}$ & $\begin{array}{l}\text { Dichotomous } \\
\text { variable }(0=\text { non- } \\
\text { risk alleles and } \\
1=\text { risk allele })\end{array}$ & $\begin{array}{l}\text { Pearson and Spearman } \\
\text { correlations, as deemed } \\
\text { appropriate, will be } \\
\text { performed to evaluate the } \\
\text { relationship between } \\
\text { markers of disease } \\
\text { progression (CD4 cell } \\
\text { count and HIV viral load) } \\
\text { and FTO SNPS. Logistic } \\
\text { regression will be used to } \\
\text { examine the relationship } \\
\text { between markers of } \\
\text { disease progression and } \\
\text { FTO SNPs over } 18 \\
\text { months. }\end{array}$ \\
\hline $2 \mathrm{~b} 2$ & HIV viral load & $\begin{array}{l}\text { HIV viral load in } \\
\text { blood }\end{array}$ & $\begin{array}{l}\text { Continuous } \\
\text { Variable }\end{array}$ & $\begin{array}{l}\text { Genotypes } \\
\text { for FTO } \\
\text { SNPs }\end{array}$ & $\begin{array}{l}5 \text { Genotypes } \\
\text { for FTO SNPs } \\
\text { determined by } \\
\text { TaqMan } \\
\text { Discrimination } \\
\text { Assay }\end{array}$ & $\begin{array}{l}\text { Dichotomous } \\
\text { variable }(0=\text { non- } \\
\text { risk alleles and } \\
1=\text { risk allele })\end{array}$ & $\begin{array}{l}\text { Pearson and Spearman } \\
\text { correlations, as deemed } \\
\text { appropriate, will be } \\
\text { performed to evaluate the } \\
\text { relationship between } \\
\text { markers of disease } \\
\text { progression (CD4 cell } \\
\text { count and HIV viral load) } \\
\text { and FTO SNPs. Logistic } \\
\text { regression will be used to } \\
\text { examine the relationship } \\
\text { between markers of } \\
\text { disease progression and } \\
\text { FTO SNPs over } 18 \\
\text { months. }\end{array}$ \\
\hline $2 b 3$ & AIDS & Presence of & Dichotomous & Genotypes & 5 Genotypes & Dichotomous & Logistic Regression will \\
\hline
\end{tabular}




\begin{tabular}{|c|c|c|c|c|c|c|c|}
\hline & $\begin{array}{l}\text { Defining } \\
\text { Conditions }\end{array}$ & $\begin{array}{l}\text { AIDS defining } \\
\text { conditions } \\
\text { recorded by } \\
\text { study physician }\end{array}$ & $\begin{array}{c}\text { variable }(0=\text { no } \\
\text { and } 1=y e s)\end{array}$ & $\begin{array}{c}\text { for FTO } \\
\text { SNPs }\end{array}$ & $\begin{array}{c}\text { for FTO SNPs } \\
\text { determined by } \\
\text { TaqMan } \\
\text { Discrimination } \\
\text { Assay }\end{array}$ & $\begin{array}{l}\text { variable }(0=\text { non- } \\
\text { risk alleles and } \\
1=\text { risk allele })\end{array}$ & $\begin{array}{l}\text { be performed to see the } \\
\text { relationship between } \\
\text { AIDS defining conditions } \\
\text { and FTO SNPs. Cox } \\
\text { Proportional Hazard } \\
\text { Survival Model will be } \\
\text { performed to compare } \\
\text { hazard ratios on time to } \\
\text { event (AIDS defining } \\
\text { condition) over } 18 \\
\text { months. }\end{array}$ \\
\hline 3 & $\begin{array}{l}\text { Leptin, CRP } \\
\text { and LPS }\end{array}$ & $\begin{array}{l}\text { Plasma leptin } \\
\text { and LPS } \\
\text { measured with } \\
\text { ELISA and } \\
\text { plasma high } \\
\text { sensitivity CRP } \\
\text { provided from } \\
\text { parent grant }\end{array}$ & $\begin{array}{c}\text { Continuous } \\
\text { Variable }\end{array}$ & $\begin{array}{l}\text { CD4 cell } \\
\text { count, HIV } \\
\text { viral load } \\
\text { and AIDS } \\
\text { Defining } \\
\text { Conditions }\end{array}$ & $\begin{array}{l}\text { CD4 cell count } \\
\text { and HIV viral } \\
\text { load in blood } \\
\text { and presence } \\
\text { of AIDS } \\
\text { defining } \\
\text { conditions } \\
\text { recorded by } \\
\text { study } \\
\text { physician }\end{array}$ & $\begin{array}{l}\text { Continuous } \\
\text { variable for CD4 } \\
\text { cell count and } \\
\text { HIV viral load } \\
\text { Dichotomous } \\
\text { variable for AIDS } \\
\text { Defining } \\
\text { Conditions ( } 0=\text { no } \\
\text { and } 1=y e s)\end{array}$ & $\begin{array}{l}\text { Pearson and Spearman } \\
\text { correlations, as deemed } \\
\text { appropriate, will be } \\
\text { performed to evaluate the } \\
\text { relationship between } \\
\text { inflammatory markers and } \\
\text { markers of disease } \\
\text { progression (CD4 cell } \\
\text { count and HIV viral load). } \\
\text { Student's t-test will be } \\
\text { performed to compare the } \\
\text { differences in } \\
\text { inflammatory markers and } \\
\text { presence of AIDS defining } \\
\text { conditions. Linear and } \\
\text { logistic regressions will be } \\
\text { used to examine the } \\
\text { relationship between } \\
\text { inflammatory markers and } \\
\text { markers of disease } \\
\text { progression over } 18 \\
\text { months. }\end{array}$ \\
\hline
\end{tabular}




\section{References}

1. Ogden CL, Yanovski SZ, Carroll MD, Flegal KM. The epidemiology of obesity. Gastroenterology 2007;132:2087-2102.

2. $\mathrm{Ng} \mathrm{M}$, Fleming $\mathrm{T}$, Robinson $\mathrm{M}$, et al. Global, regional, and national prevalence of overweight and obesity in children and adults during 1980-2013: a systematic analysis for the global Burden of Disease Study 2013. Lancet 2014; doi: 10.1016/S0140-6736(14)60460-8.

3. Letamo G. The Prevalence of, and Factors Associated with, Overweight and Obesity in Botswana. J Biosoc Sc 2011;43:75-84.

4. Prevalence of HIV, total (\% of population ages 15-49). World Bank. Available at: http://data.worldbank.org/indicator/SH.DYN.AIDS.ZS. Accessed June 9, 2014.

5. McAuley PA, Blair SN. Obesity paradoxes. J Sports Sci 2011;29:773-782.

6. Shor-Posner G, Campa A, Zhang G, et al. When obesity is desirable: a longitudinal study of the Miami HIV-1-infected drug abusers (MIDAS) cohort. J Acquir Immune Defic Syndr 2000;23:81-88.

7. Shuter J, Chang CJ, Klein RS. Prevalence and predictive value of overweight in an urban HIV care clinic. J Acquir Immune Defic Syndr 2001;26:291-297.

8. Jones CY, Hogan JW, Snyder B, et al. Overweight and human immunodeficiency virus (HIV) progression in women: associations HIV disease progression and changes in body mass index in women in the HIV epidemiology research study cohort. Clin Infect Dis 2003;37:S69-80.

9. Adeyemi OM, Vibhakar S, Evans AT. Obesity and lymphocyte subsets in virologically suppressed HIV-infected patients. Metabolism 2009;58:1285-1287.

10. Gandhi RT, Sax PE, Grinspoon SK. Metabolic and cardiovascular complications in HIV-infected patients: new challenges for a new age. J Infect Dis 2012;205:S353-S354.

11. Warriner AH, Burkholder GA, Overton ET. HIV-Related Metabolic Comorbidities in the Current ART Era. Infect Dis Clin North Am 2014;28:457-476. doi:10.1016/j.idc.2014.05.003.

12. Razquin C, Marti A, Martinez JA. Evidences on three relevant obesogenes: MC4R, FTO and PPARy. Approaches for personalized nutrition. Mol Nutr Food Res 2011;55:136-149.

13. Chung WK, Leibi RL. Considerations regarding the genetics of obesity. Obesity (Silver Spring, MD) 2008;16:S33-S39. 
14. Curti ML, Jacob P, Borges MC, Rogero MM, Ferreira SRG. Studies of Gene Variants Related to Inflammation, Oxidative Stress, Dyslipidemia, and Obesity: Implications for a Nutrigenetic Approach. J Obes 2011;2011:497401. doi: $10.1155 / 2011 / 497401$

15. Bussmann $\mathrm{H}$, Wester $\mathrm{CW}$, Thomas A, et al. Response to zidovudine/didanosinecontaining combination antiretroviral therapy among HIV-1 subtype C-infected adults in Botswana: two-year outcomes from a randomized clinical trial. J Acquir Immune Defic Syndr 2009;51:37-46.

16. De Cock KM, El-Sadr WM. When to start ART in Africa: an urgent research priority. N Engl J Med 2013;368:886-889. doi:10.1056 /NEJMp1300458.

17. Access to Antiretroviral Therapy in Africa. Status report on progress towards the 2015 targets. Available at:

http://www.unaids.org/sites/default/files/media asset/20131219 AccessARTAfric aStatusReportProgresstowards2015Targets en 0.pdf. Accessed August 27, 2014. 


\section{CHAPTER II: LITERATURE REVIEW}

\section{Obesity Paradox}

Gruberg and colleagues ${ }^{1}$ coined the term "obesity paradox" after rejecting their original hypothesis and finding that those who were overweight $\left(\mathrm{BMI}=25-30 \mathrm{~kg} / \mathrm{m}^{2}\right)$ or obese $\left(\mathrm{BMI}>30 \mathrm{~kg} / \mathrm{m}^{2}\right)$ had lower mortality rates 1 year after undergoing percutaneous coronary intervention. However, as early as 1982 this paradox was documented in dialysis patients by Degoulet et al., ${ }^{2}$ which also showed a protective effect of BMI on overall and cardiovascular related mortality. This paradox has been documented in cardiovascular and non-cardiovascular diseases with mortality and other disease-related outcomes, especially in diseases associated with cachexia and wasting. ${ }^{3}$

The mechanisms of the obesity paradox are not well understood. Valentijn et al., ${ }^{4}$ described several causes and their overlapping hypotheses to try to explain the obesity paradox in the surgical population, however the hypotheses can also be extended to other conditions, including HIV. These hypotheses are shown below in Figure1.

Figure 1: Possible Causes of the Obesity Paradox and its' Multifactorial Origin with Overlapping Hypotheses ${ }^{4}$

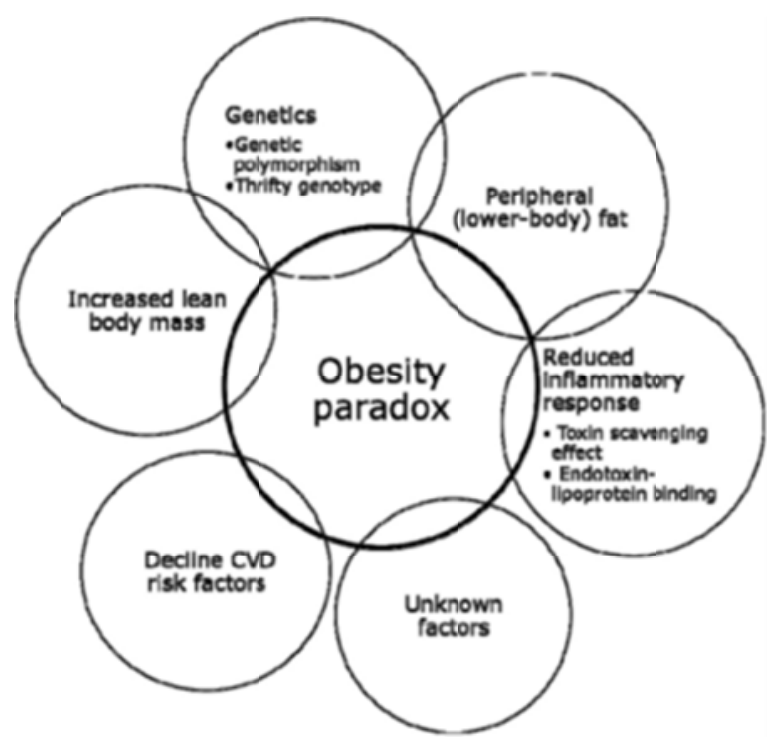




\section{Potential Mechanisms for the Obesity Paradox}

BMI does not differentiate between fat and lean body mass and cannot account for the quantity of adiposity of an individual. ${ }^{5}$ Some investigators have suggested the use of waist circumference as a measurement of body fat distribution instead of BMI since it has been shown to be associated with all-cause mortality ${ }^{6}$ and inflammatory markers ${ }^{7,8}$ independent of BMI. Visceral or abdominal adiposity has been shown to be associated with an inflammatory state ${ }^{9}$ however, BMI does not indicate fat distribution in visceral, peripheral or lower body. Therefore, the positive outcomes in the overweight/obese populations that have been observed may be due to variations of body fat mass and presence of a higher proportion of lean body mass.

Bacterial lipopolysaccharide or LPS is an endotoxin and a stimulator of inflammatory cytokine production and lipoproteins can bind LPS. Models of endotoxaemia in mice and rats have shown that lipoproteins such as LDL, VLDL, HDL, triglycerides and chylomicrons can affect LPS bioactivity..$^{10-13}$ Although obesity is associated with an increase in inflammation, there may be an obesity paradox present in some conditions where a reduced inflammatory response is observed. This hypothesis has been coined the "endotoxin-lipoprotein hypothesis." ${ }^{14}$ The theory is that LPS binds to lipoproteins through the generation of micelles, therefore reducing cytokine proliferation and inflammation. ${ }^{15}$ Rauchhaus et al. ${ }^{10}$ proposed that higher levels of cholesterol may be beneficial since lipoproteins can moderate the inflammatory immune response.

Valentijn et al., ${ }^{4}$ also considers genetics as a possible explanation for the survival advantage in overweight/obese. Genetic polymorphisms may have variable effects on body composition through its effect on food intake, energy expenditure and BMI. ${ }^{16}$ These variable effects may produce differing survival effects in the overweight/obese populations. 
This study examined the obesity paradox in a Botswana population with HIV and ART naïve. The impact of obesity on HIV disease progression over time were explored. The relationship between being overweight/obese and HIV disease progression and its interrelationship between genetic propensity for obesity and inflammatory markers was investigated.

\section{Obesity in Botswana}

Growth in economy, urbanization, and diminished physical activity is contributing to a rise in obesity in African countries, such as Botswana. ${ }^{17}$ The prevalence of overweight and obesity in 2011 were different throughout sub-Saharan Africa and generally was higher in women compared to men. ${ }^{17}$ Botswana has the following rates of overweight $\left(18.5-24.9 \mathrm{~kg} / \mathrm{m}^{2}\right): 53.5 \%$ in women and $41.6 \%$ in men, and obesity $\left(>25 \mathrm{~kg} / \mathrm{m}^{2}\right) 17.7 \%$ in women and $6.9 \%$ in men. ${ }^{18}$ A nationally representative study ${ }^{19}$ showed that approximately $23.3 \%$ of women were overweight compared to $12.9 \%$ in men, and $15.7 \%$ of women compared to $3.2 \%$ of men were obese. The mean BMI for women and men were $24.4 \mathrm{~kg} / \mathrm{m}^{2}$ and $21.7 \mathrm{~kg} / \mathrm{m}^{2}$ respectively. Increasing age and education was associated with higher BMI. BMI increased in women with high parity and remained constant for men. Data on overweight and obese and its relationship to health outcomes are lacking in the general and HIV populations in Botswana.

\section{HIV and Obesity}

In 2008 , an estimated 1.4 billion people around the world were obese and about $65 \%$ of the population in the world live in countries where more people die from being overweight and obese than from being underweight. ${ }^{20}$ An increase of obesity has also been observed in HIV+ adults, especially when on antiretroviral treatment (ART), ${ }^{21}$ and 
rates of obesity are more common now than the occurrence of wasting in developed countries. ${ }^{22,23}$ It's been estimated that in sub-Saharan Africa $10 \%$ of women had a BMI of less than $18.5 \mathrm{~kg} / \mathrm{m}^{2}$ with wasting still prevalent in some areas. ${ }^{24}$ However, subSaharan Africa is experiencing a nutrition transition with a rapid rise in overweight and obesity. ${ }^{25}$ Studies conducted to investigate obesity and its effect on HIV disease progression have so far been inconclusive, with some studies reporting an association and others reporting no association between CD4 cell counts, a measure of HIV disease progression, and obesity. ${ }^{21,26-29}$

\section{HIV Disease Progression and Obesity}

Studies have shown that obesity may be protective of further HIV disease progression before initiation of ART. Jones et al. ${ }^{27}$ showed in 871 women who were recruited from a multicenter prospective cohort in the United States (US) that a higher baseline BMI was associated with a lower chance of reaching CD4 cell count $<200$ cells/ $\mu \mathrm{L}$ for the first time. All women were ART naïve at baseline. A higher BMI was also negatively associated with experiencing HIV-related events, with a 3.1 times greater odds of HIV-related death in the lowest BMI category compared to those in the highest category $(95 \% \mathrm{Cl}, 1.2-8.1)$. An average change in CD4 cell count of 1.65 cells $/ \mu \mathrm{L}$ per unit change in $\mathrm{BMI}(95 \% \mathrm{Cl}, 0.05-3.25)$ was experienced and the authors indicated that, positive changes in BMI tended to be associated with positive changes in CD4 cell count, even controlling for previous CD4 cell count and BMI, albeit not significant. ShorPosner and colleagues ${ }^{26}$ studied 125 HIV+ ART naïve adults in Miami, Florida. They followed over 18 months HIV+ obese $\left(\mathrm{BMI}>27 \mathrm{~kg} / \mathrm{m}^{2}\right)$ adults. Patients had proportionally lower clinically significant decrease in CD4 cell count (decrease of $>25 \%$ cells from baseline $)$ in obese than nonobese HIV+ adults $(18.8 \%$ vs. $60.5 \%, p=0.004)$. In addition, 
BMI during the 18 months was negatively associated with death, even after adjusting for CD4 cell count of $<200$ cells $/ \mu \mathrm{L}$ at baseline. Shuter et al. ${ }^{28}$ through a retrospective review of 189 medical records from New York, showed that being overweight was independently associated with lack of an AIDS diagnosis before clinic enrollment $(\mathrm{OR}=3.16 ; \mathrm{Cl}: 1.44,6.96)$. In addition, lower baseline BMI and decreasing BMI during follow-up were independently predictive of advancement to AIDS.

Currently, only one study has shown that immune markers (CD3, CD8, and total lymphocyte counts) were associated with obesity in HIV+ ART treated adults with undetectable viral loads. Adeyemi et al. ${ }^{29}$ conducted a study with $216 \mathrm{HIV}+$ patients with diabetes in Chicago and demonstrated that obese patients (BMI $30-39.9 \mathrm{~kg} / \mathrm{m}^{2}$ ) had CD3 counts $26 \%$ higher than patients with normal BMI $(p=0.004)$ and CD8 counts $28 \%$ higher ( $p=0.01$ ), after controlling for age, sex, ethnicity, renal function, A1C, and duration since HIV diagnosis. The result may also be evaluated in a dose-response manner as an absolute increase in CD3 counts of 27 and CD8 of 16 for every increase of $1 \mathrm{~kg} / \mathrm{m}^{2}$ in BMI. There was also a $17 \%$ higher total lymphocyte count among the obese patients due to the higher CD3 and CD8 cells after controlling for the same covariates $(p=0.04)$.

Availability of longitudinal studies on BMI and HIV disease progression are lacking. A study conducted by Crum-Cianflone et al.$^{30}$ compared immune cell counts and BMI in 1,097 HIV+ patients in seven centers throughout the US in the pre-ART and ART eras. They showed that, at the time of HIV diagnosis, white blood cell count and immune counts (CD4, CD8, CD4/CD8 ratio, CD3, CD19 and CD56) were not statistically significant by BMI categories. In a longitudinal analysis those diagnosed in the pre-ART era had less mean postdiagnosis decreases in white blood cell count, total lymphocyte count, CD4 cell count, CD4\%, and CD4/CD8 ratio as BMI category increased (all with $P<0.05)$. Obese participants who were diagnosed in the ART era had significantly higher 
increases in CD4 cell counts, CD4\% and CD4/CD8 ratio (all with $P<0.05$ ) compared to normal weight participants. A longitudinal retrospective study in HIV+ ART naïve individuals in South Carolina who were starting ART was conducted by Johnson et al. ${ }^{31}$ They demonstrated that when comparing normal weight individuals, those who were obese had larger increases in CD4 cell count (5.5 cells/uL, $P<0.001)$. Mean CD4 cell count in the obese group was higher at diagnosis $(611.2$ cells $/ \mu \mathrm{L})$ than the normal weight group (550.5 cells/ $\mu \mathrm{L}, P<0.019)$. Excess weight in the pre-ART era and even after initiation of ART seems protective of disease progression and contributes to immune recuperation, possibly by preserving energy and nutritional stores in order to deal with HIV and AIDS-related illnesses.

Factors associated with weight gain were investigated in a study conducted by Tate et al. ${ }^{32}$ The participants included in the study were from Alabama, ART naïve and initiating ART. Over two years, the prevalence of overweight/obesity increased from $45 \%$ to $56 \%$. Those with a BMI of $<18.5 \mathrm{~kg} / \mathrm{m}^{2}$ had lower CD4 cell counts and higher viral load at baseline $(P<0.05)$ at baseline than the rest. Greater increases in BMI were observed in patients with baseline CD4 count $<50$ cells $/ \mu \mathrm{L}$ and boosted protease inhibitor use, but did not account for all of the variation observed in weight change. Obesity was highly prevalent, however, and the study did not examine how weight gain affected disease progression.

The protective effect provided by obesity has been hypothesized to be related to extra available energy in the form of fat available for use in time of crisis during the HIV disease that would spare protein's use ${ }^{33}$ and also help to preserve the immune system, especially innate immunity that is not directly affected by the infection. ${ }^{28,34} \mathrm{HIV}$ and its secondary infections are known to generate a hypermetabolic state that is sustained throughout the disease. ${ }^{35}$ The HIV patient is susceptible to infections, in which the body 
will require energy to battle continuous infections and immune activation. Those who are obese may also have a genetic advantage in maintaining fat stores and utilizing energy more efficiently to fuel the immune system. Mechanistic studies in this area are needed.

\section{HIV Disease Progression and Body Composition}

Although BMI can provide a simple measure of obesity, its association with body fat mass can vary by age, gender, race/ethnicity, and degree of fitness. ${ }^{36,37}$ Measuring body composition to be able to differentiate between body compartments such as lean body mass and fat mass can provide useful information and can be easily completed with the use of bioelectrical impedance (BIA). A safe electric current can be sent through the body to measure resistance and body fat will provide more resistance than lean mass. With the use of equations body fat can be estimated. ${ }^{38}$ In addition, BIA can provide an estimate of the amount of intracellular and extracellular water and metabolically active tissues, known as body cell mass. In HIV, BIA has been shown to be an effective approach to detect total and area specific fat mass. ${ }^{39}$ While alterations in body composition, also known as HIV associated lipodystrophy syndrome (HALS) ${ }^{40}$, have been well-documented in patients taking ART, alterations in body composition and its association to HIV disease progression in ART naïve patients are not as well known.

Some studies have shown significant associations between body composition measurements and HIV disease progression in ART naïve adults. In a study conducted by Swanson et al., ${ }^{41}$ in 56 HIV infected women in Chicago, bioelectrical impedance was used to characterize body composition and examine its relationship with measures of HIV disease. Correlations were found with positive associations with CD4 cell count and fat-mass adjusted for height $(r=0.32, P=0.01)$. Body cell mass adjusted for height was 
also correlated with viral load $(r=0.32, P=0.05)$. Visnegarwala and colleagues ${ }^{42}$

analyzed gender differences in body composition and stage of HIV disease in 422 HIV+ ART naïve adults from patients recruited in 15 US cities. In men, body cell mass was inversely associated with prior AIDS defining conditions (coefficient $-1.7 \mathrm{~kg}, P<0.005$ ) and HIV viral load $(-0.92 \mathrm{~kg}, P=0.02)$. In women, those with prior AIDS defining conditions had lower total body fat $(-9.54 \mathrm{~kg}, P<0.005)$ and total body fat was also associated with CD4 cell count $(+1.64 \mathrm{~kg}, P=0.02)$. Hamill et al.$^{43}$ compared body composition in South African women with CD4 cell count $>350$ cells $/ \mu L(n=74)$ and low CD4 cell count $(\sim 200$ cells $/ \mu L)(n=74)$. Those with CD4 cell count $>350$ cells $/ \mu L$ had significantly higher fatmass in $\mathrm{kg}(P<0.001)$ and lean body mass in $\mathrm{kg}(P=0.005)$. In addition, the group with higher CD4 cell count had a higher fat mass squared/lean body mass squared ratio $(P=0.002)$. They concluded that biological variations between men and women may have contributed to the different findings with the different body compartments and disease progression parameters. The studies conducted on body composition in ART naïve HIV infected adults had a cross-sectional design and included populations in the US. Changes may occur through time in body composition that may ultimately have an effect on HIV disease progression.

\section{The Fat Mass and Obesity Associated (FTO) Gene in African Populations}

The Fat Mass and Obesity Associated (FTO) gene was first identified in $2007^{44}$ and has been associated with obesity and obesity related traits. ${ }^{45,46}$ The gene was originally found in mice and was responsible for the fused toe $(\mathrm{Ft})$ phenotype and also provided the gene its name. ${ }^{47}$ The hypothalamus is the site where the FTO gene is mainly expressed ${ }^{48}$ and may be involved in energy homeostasis, ${ }^{49}$ and fat cell lipolysis

which may regulate body fat. ${ }^{50}$ Specifically, the single nucleotide polymorphism (SNP) of 
the FTO gene rs9939609 A allele is most commonly associated with obesity. ${ }^{44,46,51}$ Five of the SNPs previously shown to be associated with BMI were included in this study (rs9939609, rs1421085, rs8050136, rs17817449, and rs1121980). Currently, there are no published studies on the FTO gene and its association to obesity and adipokines in HIV+ patients or in a population in Botswana.

Henning and colleagues ${ }^{52}$ were the first to investigate the polymorphisms of the FTO gene in an African population. The effect of the FTO gene on BMI was assessed in 2208 slender Gambian children and adults. In adults, BMI and weight for height was not associated with any of the genotypes of the FTO gene. In addition, the $95 \%$ confidence interval of the effect size for variant rs9939609 did not correspond to that of Europeans reported in other research studies. The findings of this study may not be relevant to other populations where obesity is prevalent or an abundance of food is available.

Adeyemo et al. ${ }^{53}$ conducted a study that assessed the genetic variation in the FTO gene in 517 West Africans and 968 African Americans and its association to obesity as measured by BMI, waist circumference and fat mass percentage. The variant of the FTO gene rs9939609 did not show any associations with obesity in the two populations, however two other gene variants rs1121980 and rs7204609 were associated with obesity in the West African participants $(p<0.05)$.

A genetic association study completed by Lombard et al, ${ }^{54}$ assessed the association of SNPs from FTO and other obesity related genes with BMI in 990 black adolescent South Africans. Seven FTO SNPs were included; rs9939973, rs9940128, rs1421085, rs1121980, rs17817449, rs8050136, and rs9939609. The FTO SNP rs1781749, the minor allele or G, was associated with increased BMI (effect size 1.9, $p<0.05)$ after adjusting for sex, age, and pubertal age. Sex specific associations were not found with SNPs of the FTO gene. In a model that included the SNPs for FTO 
rs1781749, LEP (leptin) rs10954174, LEP rs6966536, and MCAR (melanocortin 4 receptor) rs17782313 the effect size for the FTO SNP was 2.2, $p=0.007$. This finding was adjusted for age, sex and sex-specific pubertal age. The effect corresponded to the estimated percent change in BMI of each allele independent of the covariates. Based on the available data from studies on FTO, the most common SNP rs9939609 was not associated with BMI in the African populations but concluded that more studies are needed to investigate these relationships in other African populations. The results from this study are relevant to Botswana, who are closely related culturally and genetically to South Africans, with whom they share borders, language and ancestors. ${ }^{55}$ However, Botswana and other African nations are known to be a heterogeneous population with many ethnic groups. ${ }^{56}$ Replication studies in diverse African populaces are need to identify the SNPs that may cause the variations seen in obesity relevant to the pertaining population. GWAS studies in African populations are lacking to identify novel SNPs that are appropriate to the population is of importance.

\section{The Fat Mass and Obesity Associated (FTO) Gene and HIV Disease Progression}

Currently, in the literature there are no know studies evaluating markers of HIV disease progression and SNPs of the FTO gene in an HIV mono-infected population. Recently, Pineda-Tenor et al. ${ }^{57}$ carried out a cross-sectional study in $261 \mathrm{HIV} / \mathrm{HCV}$ coinfected participants in Spain. Those with the rs9939609 AA genotype had higher levels of BMI $(p=0.016)$ when compared to the AT/TT genotypes remained significant after adjusting for age, gender, markers of HIV disease progression, markers of HCV disease progression, liver fibrosis and ART. However, the genotypes for rs9939609 were not associated with CD4 cell count or HIV viral load. 


\section{Obesity and Inflammation}

Inflammation is a condition in which the homeostasis between pro and antiinflammatory markers in the body are out of balance and may lead to a prolonged stage of inflammation which in turn may affect the progression or outcomes of many conditions and/or diseases. ${ }^{58}$ Obesity is known to be associated with a chronic state of low grade inflammation. Inflammation in obesity is due to many mechanisms which include disordered secretion of adipokines within adipose tissue resulting in insulin resistance and metabolic disorders. ${ }^{59}$ Adipokines can affect many processes in the body such as metabolism, growth, blood pressure, vascularization, coagulation and inflammation and

a variation in fat mass can change their production. ${ }^{60}$ It has also been shown that an accumulation of macrophages occurs in obesity and this affects the increased release of TNF-a, a pro-inflammatory cytokine. ${ }^{61}$ TNF- $\alpha$ release, mainly derived from macrophages, initiates a pro-inflammatory cascade of events and can block insulin activity leading to insulin resistance. ${ }^{62}$ Obesity may also reduce the production of other inflammatory products as a result of the "endotoxin-lipoprotein hypothesis." ${ }^{14}$ Higher levels of lipoproteins are usually found in obesity which can bind bacterial endotoxin such as LPS therefore affecting the release of pro-inflammatory cytokines. There is conflicting information in the literature regarding obesity and inflammation, which requires further research.

\section{HIV Disease Progression and Inflammation}

Diminishing CD4 cells is one of the main features of HIV progression and eventually the diagnosis of AIDS. There are many mechanisms described as to why a loss of immune related cells occur in HIV and inflammation is a key culprit. Loss of immune function in HIV may be due to a persistent immune activation. Inflammation is 
involved in the depletion of T-cells, and chronic immune activation drives the general and HIV-specific losses of immune function. ${ }^{63}$ Continuous inflammation induces proinflammatory cytokines which has been shown to produce thymic and T cell progenitor dysfunction. ${ }^{64}$ It has also been shown that triggered or activated CD4 cells are a favored target for viral infection and replication. Inflammation may also set up non-infected CD4 cells and other immune cells for death by programmed cell death or apoptosis. ${ }^{65}$ This constant state of inflammation also predisposes the patients to the occurrence of nonHIV related complications such as cardiovascular disease. ${ }^{66}$ The role of obesity in inflammation in HIV infection is not clear and the literature is contradictory, therefore, it is important to examine the interrelationships that exist between inflammation, obesity, and HIV disease progression to elucidate the potential mechanisms involved and how it could later be translated into clinically relevant recommendations.

\section{Pro-Inflammatory Markers}

\section{Leptin}

Adipocytokines or adipokines are biologically active molecules that are secreted by adipocytes. ${ }^{67}$ Adipose tissue, now deemed to be an endocrine organ, ${ }^{68}$ secretes hormones such as leptin that may play an important role in body weight regulation. ${ }^{69}$ Leptin was the first adipokine to be isolated and it is involved in weight, inflammatory, and immune regulation. Leptin is considered to be pro-inflammatory and can increase $T$ cell activation and cytokine release proliferation thereby promoting a Th1 response. ${ }^{69}$ Leptin levels are increased in obesity and have been shown to also act upon monocytes and prompt the release of cytokines such as TNF- $\alpha$ or IL- $6 .{ }^{70}$ Serum levels of leptin are proportional to body fat mass. ${ }^{71}$ Females tend to have higher levels of leptin due to higher body fat mass, and sex steroids may also increase leptin mRNA levels ${ }^{72,73}$ The 
adipose tissue of obese individuals contain a larger amount of macrophages that when activated will secrete cytokines such as TNF- $\alpha$ and IL-6. ${ }^{74}$

Leptin as a proinflammatory cytokine may have effects on the innate and adaptive immune responses. It has been suggested that leptin does not begin an immune response but instead may impact the outcome by inducing proinflammatory cytokines from different cell types, such as T cells. ${ }^{75}$ Inflammatory stimuli such as lipolysaccharide (LPS), a bacterial endotoxin, increases leptin gene expression and its concentration rapidly increases after the first stimulus. LPS binds to a Toll-like receptor on adipose cells and expression of other toll-like receptors occurs, which then increases the release of leptin and other inflammatory cytokines. ${ }^{76}$ Leptin also binds to CRP during an immune response. ${ }^{77}$ Leptin deficient mice have shown impaired responses to microbial pathogens such as tuberculosis. ${ }^{75,78}$ Therefore, leptin plays an important role in the immune system and may respond differently depending on the stimuli.

Leptin is considered to be a pleiotropic molecule with not only metabolic roles but also endocrine and immune regulation. ${ }^{79}$ Higher levels of leptin in some studies have been shown during infection and inflammation, however the results in human studies have been inconsistent in various diseases, including HIV ${ }^{79}$ Leptin is involved in the proliferation of T- cells including CD4 and CD8 cells. ${ }^{80}$ In addition, leptin has antiapoptotic properties for many cell types including lymphocytes. ${ }^{81}$ Higher levels of leptin found in obese individuals ${ }^{82}$ may enhance the immunity through its role in proliferation and anti-apoptotic effects on lymphocytes. The interplay between leptin and the immune response is an area of importance in HIV as it may assist in determining possible mechanisms for the protective effect of obesity often seen in HIV. 


\section{HIV Disease Progression and Leptin in HIV ART Naïve}

Most of the research on adipokines, like leptin, and HIV have been conducted in ART treated patients and information on how leptin affects HIV disease progression in HIV ART naïve is lacking. Below are a few of the studies conducted on ART naïve participants, however, some of the findings still remain inconclusive.

Changes in body fat distribution such as, lipodystrophy, is common in ART treated HIV+ persons. This side effect is closely associated with the use of Protease Inhibitors (PIs) ${ }^{83}$ Leptin levels are decreased in HIV associated lipodystrophy and the metabolic or immunological effect is only shown once the patients become hypolipidemic. ${ }^{84}$ The action of leptin is affected by ART. ${ }^{83}$

Prabha and colleagues ${ }^{85}$ investigated the role of leptin levels in the coinfection of HIV and tuberculosis (TB) in 20 HIV infected ART naïve participants, 20 HIV and TB infected ART naïve participants and 20 healthy controls in India. Mean serum levels of leptin in the group with HIV and TB was significantly lower than that of the control HIV group and healthy control group $(p<0.01)$. Women had higher levels of leptin than men in all groups, which included the HIV control group $(14 \pm 4$ vs. $5 \pm 1, p<0.01)$. In all groups leptin increased consistently with BMI and in all groups combined for every unit increase in BMI a 1.8 fold increase was observed in leptin. CD4 cell counts and leptin were not statistically correlated in any group, even after adjusting for BMI.

A study conducted in Nigeria by Onyemelukwe et al. ${ }^{86}$ examined serum leptin levels in ART naïve HIV infected adults in relation to BMI, CD4 cell count, asymptomatic and symptomatic HIV and AIDS. Groups for this study included 26 healthy HIV negative controls, 20 normal weight participants, and 20 underweight participants. The median serum leptin levels was lower in the normal weight group and underweight group compared to the control group $(Z=-2.26, p=0.024$ and $Z=-2.56, p=0.009$ respectively). 
The median leptin level of symptomatic participants were lower compared to asymptomatic participants $(27.9 \mathrm{ng} / \mathrm{mL} \mathrm{IQR}=4.9-36.4$ vs. $43.7 \mathrm{ng} / \mathrm{mL} \mathrm{IQR}=11.8-48.2, \mathrm{Z}=-$ 2.07, $p=0.038)$. Leptin levels were lower in the AIDS cases compared to the non-AIDS cases $(22 \mathrm{ng} / \mathrm{mL}, I Q R=3.8-40$ vs. $35 \mathrm{ng} / \mathrm{mL}, I Q R=25.9-45.6)$ but was not statistically significant. Female HIV+ participants had lower median leptin levels as compared to male HIV+ participants $(7.42 \mathrm{ng} / \mathrm{mL} I Q R=3.2-44.3$ vs. $35.6 \mathrm{ng} / \mathrm{mL} I Q R=27.7-43.2$, $p=0.05)$. In this study, HIV+ participants with normal weight had similar leptin levels as the healthy HIV negative controls unless there was a difference in weight or symptomatic HIV related conditions.

Azzoni et al, ${ }^{87}$ investigated the association between HIV viral load, cellular activation, and adipose tissue related measures in 83 HIV infected ART naïve South African women with a CD4+ cell count of $200-350$ cells $/ \mu \mathrm{L}$. The results showed that women with high viral load (> study median) had a higher BMI, waist circumference, subcutaneous abdominal fat, and trunk fat mass. Leptin levels were associated with BMI $(r=0.699, p<0.001)$, visceral abdominal fat $(r=0.542, p<0.0001)$ and total fat mass, $(r=$ $0.764, p<0.001)$. In a multivariate regression model the relationship between leptin levels and $\log _{10}$ viral load remained (effect estimate $=-0.0186653, p=0.03$ ), even after controlling for subcutaneous abdominal fat area. These results support a direct association between leptin levels and HIV viral replication, independent of the amount of adipose tissue. Since these women were ART naïve, they may have been newly infected which would explain the higher viral load and the reason they may be healthier suggested by the higher BMI and fat mass. The data may also suggest that the cytokine dysregulation produced by obesity and related to inflammation might not be the source of the protective effect of obesity previous to ART. Instead, the energy advantage may delay wasting and maintain an active innate immune response. The studies discussed 
above have limitations that warrant further research, including small sample sizes, inconsistent findings, and cross-sectional design. Although, some studies include African populations, heterogeneity in Africans is present and including other nations would provide relevant information to their respective regions.

\section{The Fat Mass and Obesity Associated (FTO) Gene and Leptin}

Obesity affects the release of adipokines such as adiponectin, leptin, cytokines

IL-6 and TNF- $\alpha$ from adipose tissue which may further lead to fat deposits. ${ }^{88}$ Contradictory evidence of an association with the FTO gene and adipokines and inflammatory markers exists in the literature. Zimmermann and colleagues ${ }^{89}$ did not show an association across FTO gene SNP rs9939609 genotypes and inflammatory markers including TNF- $\alpha$, IL- 6 and leptin in healthy Danish middle-aged men. A study by Zabena et al, ${ }^{90}$ investigated the association of rs9939609 SNP of the FTO gene with obesity-related measures, to assess the FTO gene expression in subcutaneous and visceral adipose fat in morbidly obese patients in Spain and the relationship with adipocytokine gene expressions. The rs9939609 A allele was more frequent in the morbidly obese patients as compared to the control group, who had no diabetes and were not obese, (0.52 and 0.34), even after controlling for age and sex (OR 2.26; 95\% Cl 1.19-4.30, $p=0.013)$. FTO mRNA expression was associated with leptin $(r=0.695$, $p<0.001)$. Qi et al, ${ }^{91}$ investigated the longitudinal relationships of the FTO gene variant rs9939609 with obesity and plasma adiponectin and leptin levels in men and women from prospective studies, The Nurses' Health Study and the Health Professional FollowUp Study. The AA genotype of the SNP rs9939609 was associated with BMI in a 26year follow-up in women $(p<0.05)$ and 16-year follow-up in men $(p<0.05)$ after adjusting for age and diabetes status and correlated with greater obesity risk during follow-up in 
both women and men in contrast to genotypes TA and TT. A trend was shown in the allele $A$ between higher leptin levels when adjusted for age $(p=0.06)$. No significant associations were seen in men with the FTO gene polymorphism and leptin levels. Terra et al. ${ }^{92}$ demonstrated that the FTO gene is associated with an anti-inflammatory profile in adipose tissue of morbidly obese $\left(\mathrm{BMI}>40 \mathrm{~kg} / \mathrm{m}^{2}\right)$ women. Adiponectin expression was greater than any other cytokine measured in both subcutaneous and visceral fat and decreased when comparing morbidly obese women to a control group $\left(\mathrm{BMl}<25 \mathrm{~kg} / \mathrm{m}^{2}\right)(4.03 \pm 0.47 \mathrm{vs} .10 .50 \pm 1.74, \mathrm{p}=0.019)$. In subcutaneous fat, FTO expression was negatively associated with BMI $(r=-0.457, p=0.004)$ and leptin $(r=-0.475$, $p=0.026$ ). Inconsistent findings were present in the studies on FTO and leptin and between genders. The FTO SNP rs9939609 was most commonly researched in the above studies. Studies with African populations on possible relationships between FTO and leptin are currently not available.

\section{C-Reactive Protein}

C-reactive protein or CRP is considered a sensitive systemic marker of inflammation and an acute phase reactant. CRP is produced and released mainly by hepatocytes in response to proinflammatory cytokines, such as IL-1 and IL-6. ${ }^{93,94}$ Within adipose tissue, adipocytes and monocyte-derived macrophages may release proinflammatory cytokines boosting hepatic production of CRP. ${ }^{95}$ Higher levels of CRP have also been associated with obesity and specifically abdominal obesity. ${ }^{96}$ High sensitivity CRP (hsCRP) allows for a lower limit of detection and a value of $>10 \mathrm{mg} / \mathrm{L}$ may indicate the presence of a subclinical infection or inflammation. ${ }^{97} \mathrm{CRP}$ is currently used in many diagnostic, clinical, and research settings as an acute and chronic measure of inflammation. ${ }^{98} \mathrm{CRP}$ is considered to be a stable molecule to measure and 
many inexpensive methodologies are available to determine CRP. ${ }^{99}$ Such measures are attractive for resource limited settings, like many countries in Africa. A recent study showed that CRP $>1.2 \mathrm{mg} / \mathrm{L}$ had a specificity of $68.87 \%$ for predicting CD4 cell counts of $<200$ cell/ $\mu \mathrm{L}$ in HIV adults, which shows that CRP may be a sensitive biomarker beyond cardiovascular disease. $^{100}$

\section{HIV Disease Progression and C-Reactive Protein in HIV ART Naïve}

Lau et al. ${ }^{101}$ examined the association between CRP and immune suppression and progression to AIDS in 513 HIV-infected men recruited into a multicenter cohort in 6 US cities who were ART naïve at baseline. CRP was negatively correlated with CD4 cell count $(r=-0.17, p<0.001)$ and positively correlated with HIV RNA levels $(r=0.20$, $p<0.001$ ). Those with higher concentrations of CRP had shorter times to AIDS (overall log-rank test, $\mathrm{P}<0.001)$. Median times to AIDS were 5.07 years $(95 \% \mathrm{Cl}$ : 4.15-7.26 years) for those with CRP levels of $1.3-2.3 \mathrm{mg} / \mathrm{L}$ and 4.48 years $(95 \% \mathrm{Cl}: 3.17,5.61)$ for those with CRP levels more than $2.3 \mathrm{mg} / \mathrm{L}$. Accelerated progression to AIDS was only seen in those with CRP levels of $>1.2 \mathrm{mg} / \mathrm{L}$. Using Cox proportional hazard models, it was observed that increased hazards for the development of AIDS in those with higher levels of CRP remained after adjusting for CD4 cell counts and $\log _{10}$ HIV viral load. CRP increased over time for participants with and without AIDS, however, those who progressed to AIDS had more of a rapid increase in CRP concentrations than those without progression to AIDS. Using a random-effects model, those that progressed to AIDS had $8.5 \%$ change per year in CRP concentrations compared to those that did not progress to AIDS, which had a $4.5 \%$ change per year. This study demonstrated a steady increase in CRP concentrations before participants' progress to AIDS. 
Guimarães et al. ${ }^{102}$ compared hsCRP between 42 HIV+ ART naïve patients and 129 HIV treated patients in Brazil. They investigated the relationship between hsCRP and cardiovascular risk factors with HIV disease progression. ART treated participants had higher levels of hsCRP compared to ART naïve participants $(1.14 \pm 1.17 \mathrm{mg} / \mathrm{l} \mathrm{vs}$. $0.3 \pm 1.16 \mathrm{mg} / \mathrm{L} ; \mathrm{p}<0.001)$. The ART treated participants had a higher percentage with values $>3 \mathrm{mg} / \mathrm{dL}$, associated with a higher cardiovascular risk, compared to the ART naive group (56\% vs. $26 \%$ : OR=3.56; $95 \% \mathrm{Cl}: 1.55-8.29, \mathrm{p}=0.001)$. There were no statistically significant correlations between CRP and measures of HIV disease progression, CD4 cell counts and HIV viral load.

Chaudhary and colleagues ${ }^{103}$ explored possible associations of CRP with CD4 cell counts and survival in 119 HIV infected ART naïve adults and 33 healthy individuals in India. CRP was negatively correlated with CD4 cell counts $(r=-0.148, p=0.045)$. Using a Cox proportional hazard model, higher CRP category $(>12 \mathrm{mg} / \mathrm{dL})$ was associated with AIDS related mortality $(\mathrm{RH}=1.23,95 \% \mathrm{Cl}: 1.12,1.25, \mathrm{p}=0.0047)$ after 1 year, albeit only 8 participants were included in this analysis. CRP was suggested by the authors as another measure of disease progression in a resource limited setting.

A retrospective study by Baker et al. ${ }^{104}$ compared markers of inflammation and coagulation in 254 ART naïve or not receiving ART for 6 months to 128 patients who initiated ART from various centers in the US during a 6 months follow-up. At baseline there were no statistical differences in CRP between the ART naïve or the ART initiated group. In addition, CRP was not associated with baseline CD4 count or HIV RNA level. After initiating ART, CRP did not significantly change from baseline.

A published study of inflammatory markers in 546 HIV pre-ART participants by Ledwaba and colleagues ${ }^{105}$ looked at whether elevated levels of inflammatory markers would be associated with increased risk of death after initiation of ART in South African 
participants. Prior to commencing ART, median hsCRP was significantly higher in the case group that included those who died during a median follow-up period of 24 months compared to a control group containing 80 uninfected adults $(11.25$ IQR=2.90-51.90 vs. 3.6 IQR=1.50-11.30, $P=<0.001)$. At baseline participants with advanced HIV infection had lower levels of hsCRP compared to patients with early HIV (3.05 IQR=1.2-6.2 vs. 4.30 IQR=1.95-12.3, $P=0.002)$. Advanced disease, which was accompanied by higher levels of CRP, was related to death after starting ART. The studies investigating the relationship between CRP and HIV disease progression have inconsistent results as some did not show significant findings. Since CRP is affected by ART, studies that include ART naïve are of importance to see the true associations with HIV disease progression. Studies among African populations are limited in this area of research.

\section{The Fat Mass and Obesity Associated (FTO) Gene, and CRP}

Adipose tissue may also determine levels of circulating CRP through IL-6, as its presence in adipose tissue affects production of CRP by the liver. ${ }^{106}$ FTO seems to affect the amount of adipose tissue and therefore levels of CRP. In a recent study completed by Fall et al., ${ }^{107}$ over ninety-one thousand adults of European descent contributed to an analysis used to confirm causal effects of adiposity, the FTO gene variant rs9939609 and cardiometabolic traits, including CRP. Both BMI and FTO SNP were associated with CRP $(P<0.05)$. Fisher et al. ${ }^{108}$ studied the association of the FTO rs9939609 SNP and CRP levels in 2,415 adult men and women in Germany and found that using a regression model that FTO SNP was associated with higher CRP levels in men ( $14 \%$ higher) and women $(\sim 12 \%, P=0.02)$ for the $\mathrm{A}$ allele. This model was adjusted for age, BMI, waist-to-hip ratio, common diseases (myocardial infarction, stroke, and diabetes), education, engagement in sports, and smoking. Zimmerman and 
colleagues $^{89}$ also looked at the association of CRP and FTO rs9939609 SNP. No statistically significant results analyzing CRP were observed. Studies on FTO SNPs and its relationships with adipokines and markers of inflammation such as CRP that were discussed above have been mainly conducted using European populations. Studies with African populations are lacking. Overall, studies in this subject are limited and more research is warranted to examine possible pleiotropic effects of FTO.

\section{Lipopolysaccharide (LPS)}

Microbial translocation or the movement of bacterial products from the intestinal lumen into systemic circulation is measured by bacterial products such as lipopolysaccharide (LPS). ${ }^{109}$ Microbial translocation may have a role in persistent immune activation and can provoke pro-inflammatory reactions. ${ }^{110}$ During HIV, microbial translocations may occur due to epithelial damage to the intestine, loss of T-helper-17 cells and a reduced removal of microbial products by phagocytes are observed. ${ }^{110}$ Increased secretion of pro-inflammatory cytokines can also contribute to increased T cell activation and specifically can increase CD8 T cell activation and depletion of CD4 T cells. ${ }^{111}$ Conversely, a theory for the obesity paradox includes the endotoxin-lipoprotein hypothesis. ${ }^{14}$ This theory states that during obesity there are a large number of lipoproteins circulating and LPS binds to lipoproteins through the formation of micelles in the gut. Lower circulating LPS would reduce the inflammatory response. This hypothesis merits investigation in a HIV infected population that is ART naïve that may be protective of further disease progression by obesity. 
HIV Disease Progression and Lipopolyssacharide (LPS) in HIV Infection without ART

Redd et al. ${ }^{112}$ observed in 107 HIV+ ART naïve adults the longitudinal relationship between microbial translocation, which included LPS, and inflammatory cytokine response in a cohort with varying rates of HIV disease progression in Uganda. Markers of microbial translocation were also compared to 24 HIV uninfected adults in the US. At baseline there were no statistical differences in the levels of LPS between the HIV infected group in Uganda and the US uninfected group. When comparing groups stratified by HIV disease progression there were still no differences at baseline or over time in LPS. The authors proposed that the different levels of microbial translocation markers such as LPS, may be a symptom but not a direct cause of HIV disease progression.

Marchetti and authors ${ }^{113}$ investigated microbial translocation, as measured by LPS, in 379 HIV ART naïve participants in Italy. Participants were recent seroconverters with high CD4 cell counts, and who were followed for an average of 3 years. Participants were separated into two groups based on the median LPS level $(110 \mathrm{pg} / \mathrm{mL})$ and there were no differences at baseline in CD4 cell counts and HIV viral load between the groups. In a subset that included 17 participants, LPS did not change significantly over time (13-25 months). The group above the LPS median had a shorter median time to event (AIDS defining condition, death, CD4 cell count $<200$ cells $/ \mu \mathrm{L}$ or start of ART, whichever happened first) of 1.5 years $(95 \% \mathrm{Cl}: 1.0,2.0)$ as compared to those below the median who had an average time to event of 4 years (95\% Cl: $3.1,5.6), P=0.0002$. This association remained significant after controlling for proinflammatory cytokines, age, CD4, viral load, HCV, HBV and duration of HIV (RH=1.85, 95\% Cl: 1.32, 2.58, $\mathrm{p}<0.001)$. In this study LPS was a strong predictor of HIV disease progression 
independent of CD4 cell count and HIV viral load. In summary, the evidence points towards an association between LPS levels and disease progression, but is weak in elucidating whether the relationship is of cause-and-effect or mediated by other factors. Additionally, few studies are available on LPS in HIV ART naïve participants and the sample size over time quite small. Currently, there are no published literature examining the relationship between FTO SNPs and LPS in humans.

\section{Summary}

There is evidence in the literature of an obesity paradox, where higher BMI seems to be protective of mortality and disease-related outcomes in several conditions, including HIV. ${ }^{3}$ Obesity may boost the innate immune system even in ART, which is probably why it is protective before ART. Fat available for use in time of crisis in HIV disease may spare protein's use. ${ }^{33}$ However, factors generating this paradox are not well understood and the mechanism for the associated benefits of higher BMI are lacking. The prevalence of overweight and obesity are increasing globally, including sub-Saharan countries like Botswana. ${ }^{17}$ Botswana also has the second highest prevalence rate of HIV in the world. ${ }^{114}$ Before the initiation of ART, BMI and body composition measures such as fat mass and body cell mass seem to be protective of HIV disease progression, however, longitudinal studies in African populations are lacking.

Studies that examine the relationships between being overweight/obese and HIV disease progression and its interrelationship between genetic propensity for obesity and inflammatory markers, such as the study reported in this dissertation, are needed. The studies conducted on body composition in HIV infected, ART naïve patient populations were cross-sectional and included populations in the US. Changes may occur through time in body composition that may ultimately have an effect on HIV disease progression. 
Replication studies in diverse African populations are needed to identify the SNPs that may cause the variations seen in obesity that is relevant pertaining to the population. Most of the studies discussed above have limitations that warrant further research, including small sample sizes, inconsistent findings, and cross-sectional design. In addition, studies that include ART naïve patients are of importance in determining the true associations with HIV disease progression. Although, some studies include African populations, heterogeneity among Africans is present and including other ethnicities is likely to provide relevant information. The role of obesity in inflammation in HIV infection is not clear and the literature is contradictory, therefore, it is important to examine the interrelationships that exist between inflammation, overweight/obesity, and HIV disease progression to elucidate the potential mechanisms involved and how it could later be translated into clinically relevant recommendations. 
Table 1: Studies Conducted in Obesity and HIV Disease Progression

\begin{tabular}{|c|c|c|c|c|}
\hline $\begin{array}{l}\text { Author/Study } \\
\text { Design }\end{array}$ & Study Purpose & Population & $\begin{array}{l}\text { Main } \\
\text { Outcome(s) }\end{array}$ & Study Findings \\
\hline $\begin{array}{l}\text { Johnson et al, } \\
2014 \\
\text { Retrospective } \\
\text { Longitudinal } \\
\text { Cohort Study }\end{array}$ & $\begin{array}{l}\text { To investigate the longitudinal } \\
\text { association of BMI at HIV } \\
\text { diagnosis with disease } \\
\text { progression as evaluated by } \\
\text { CD4 cell counts obtained } \\
\text { during routine medical care. }\end{array}$ & $\begin{array}{l}396 \text { ART naïve } \\
\text { and had one } \\
\text { follow-up visit }\end{array}$ & $\begin{array}{l}\text { CD4 cell } \\
\text { counts }\end{array}$ & $\begin{array}{l}\text { Longitudinally, the mean CD4 count was } \\
611.2 \text { cells } / \mathrm{mm}^{3} \text { for obese individuals, } 598.1 \\
\text { cells } / \mathrm{mm}^{3} \text { for overweight individuals and } \\
550.5 \mathrm{cell} s / \mathrm{mm} 3 \text { for normal weight individuals. } \\
\text { When compared to the normal weight } \\
\text { category, the obese category had significantly } \\
\text { larger increases in CD4 count ( } 5.5 \text { cells } / \mathrm{mm}^{3} \text {, } \\
P<0.001) \text { versus the overweight category (- } \\
\left.2.1 \text { cells } / \mathrm{mm}^{3}, P<0.001\right) \text {. }\end{array}$ \\
\hline $\begin{array}{l}\text { Tate et al., } 2012 \\
\text { Prospective } \\
\text { Longitudinal } \\
\text { Cohort Study }\end{array}$ & $\begin{array}{l}\text { To evaluate factors associated } \\
\text { with change among patients } \\
\text { receiving ART. }\end{array}$ & $\begin{array}{l}681 \text { ART } \\
\text { treatment naïve } \\
\text { patients who } \\
\text { maintained ART } \\
\text { therapy for } 2 \\
\text { years. }\end{array}$ & BMI & $\begin{array}{l}\text { At } 24 \text { months, } 20 \% \text { of patients moved from } \\
\text { normal to overweight/obese or overweight to } \\
\text { obese BMI categories. Underweight } \\
\text { participants had lower CD4 counts and Higher } \\
\text { viral load at ART initiation. Greater increases } \\
\text { in BMI were observed in patients with } \\
\text { baseline CD4 count }<50 \text { cells } / \mu \mathrm{L} \text { and boosted } \\
\text { protease inhibitor use, but did not account for } \\
\text { all of the variation observed in weight change. }\end{array}$ \\
\hline $\begin{array}{l}\text { Crum-Cianflone } \\
\text { et al., } 2011\end{array}$ & $\begin{array}{l}\text { To investigate relationship } \\
\text { between body weight and a } \\
\text { variety of immune cell counts } \\
\text { at diagnosis and over the } \\
\text { course HIV infection among a } \\
\text { cohort of documented HIV } \\
\text { seroconverters who had serial } \\
\text { immune cell measurements } \\
\text { and longitudinal weight data. }\end{array}$ & $\begin{array}{l}1097 \text { HIV } \\
\text { seroconverters } \\
\text { who were } \\
\text { participants in } \\
\text { the US Military } \\
\text { HIV Natural } \\
\text { History Study } \\
\text { (NHS) ( } 96 \% \\
\text { male). }\end{array}$ & $\begin{array}{l}\text { Immune cell } \\
\text { counts }\end{array}$ & $\begin{array}{l}\text { Immune cell counts at HIV diagnosis did not } \\
\text { significantly differ by BMI category. In the } \\
\text { longitudinal models for those diagnosed } \\
\text { before the advent of the highly active } \\
\text { antiretroviral therapy (HAART) era, mean } \\
\text { postdiagnosis decreases in the white cell } \\
\text { count, total lymphocyte count, CD4 count, } \\
\text { CD4 percentage, and CD4/CD8 ratio were } \\
\text { less as the BMI category increased (all with P } \\
\text { values of <0.05). Among HIV seroconverters } \\
\text { diagnosed in the HAART era, obese } \\
\text { compared to normal-weight patients had }\end{array}$ \\
\hline
\end{tabular}




\begin{tabular}{|c|c|c|c|c|}
\hline & & & & $\begin{array}{l}\text { significantly smaller increases in CD4 counts, } \\
\text { CD4 percentages, and the CD4/CD8 ratio (all } \\
\text { with } \mathrm{P} \text { values of }<0.05 \text { ). Similar findings were } \\
\text { also noted among underweight versus } \\
\text { normal-weight patients. }\end{array}$ \\
\hline $\begin{array}{l}\text { Adeyemi et al., } \\
2009 \\
\text { Cross-sectional } \\
\text { Study }\end{array}$ & $\begin{array}{l}\text { To explore the effects of } \\
\text { obesity on lymphocyte } \\
\text { subsets in HIV-positive } \\
\text { patients with diabetes. }\end{array}$ & $\begin{array}{l}216 \text { HIV+ } \\
\text { patients with } \\
\text { Diabetes on } \\
\text { HAART and } \\
\text { undetectable } \\
\text { viral load. }\end{array}$ & $\begin{array}{l}\text { White blood } \\
\text { cell count and } \\
\text { the following } \\
\text { lymphocyte } \\
\text { subgroups, } \\
\text { defined by } \\
\text { surface } \\
\text { antigens: CD3 } \\
\text { (T cells), CD4 } \\
\text { (helper T cells), } \\
\text { CD8 (cytotoxic } \\
\text { or suppressor } \\
\text { T cells), CD19 } \\
\text { (B cells), and } \\
\text { CD56 (natural } \\
\text { killer cells). }\end{array}$ & $\begin{array}{l}\text { As BMI increased, there were significant } \\
\text { increases in CD3, CD8, and total lymphocyte } \\
\text { counts. For total white blood cell count and } \\
\text { the other lymphocyte subgroups (CD4, CD19, } \\
\text { and CD56), the relationship with BMI was not } \\
\text { significant. Obese patients had CD3 counts } \\
26 \% \text { higher than patients with normal weight } \\
\text { and CD8 counts } 28 \% \text { higher, controlling for } \\
\text { age, sex, ethnicity, renal function, HbA1c, and } \\
\text { duration since HIV diagnosis. }\end{array}$ \\
\hline $\begin{array}{l}\text { Jones et al., } \\
2003 \\
\text { Longitudinal } \\
\text { Prospective } \\
\text { Cohort Study }\end{array}$ & $\begin{array}{l}\text { To examine the association of } \\
\text { BMI with HIV disease } \\
\text { outcomes. }\end{array}$ & $\begin{array}{l}871 \text { HIV+ } \\
\text { women } 16-55 \\
\text { years of age } \\
\text { with history of } \\
\text { IDU or high-risk } \\
\text { sexual contact } \\
\text { without prior } \\
\text { AIDS-defining } \\
\text { clinical illness } \\
\text { and ART naïve } \\
\text { at baseline }\end{array}$ & $\begin{array}{l}\text { Time to first } \\
\text { CD4 cell count } \\
<200 \\
\text { cells/mm3, first } \\
\text { CD4 cell count } \\
<100 \\
\text { cells/mm3, } \\
\text { opportunistic } \\
\text { infection and } \\
\text { HIV-related } \\
\text { death }\end{array}$ & $\begin{array}{l}\text { Mean CD4 cell count at baseline } \\
\text { progressively higher and mean log viral load } \\
\text { progressively lower as BMI increased. A } \\
\text { higher baseline BMI was associated with a } \\
\text { lower rate of occurrence of the first CD4 <200 } \\
\text { cells/mm3. In analysis using time-varying } \\
\text { BMI, underweight and normal women had } \\
\text { increased risk of clinical AIDS and } \\
\text { underweight women had increased risk of } \\
\text { HIV-related death, compared with obese } \\
\text { women. }\end{array}$ \\
\hline
\end{tabular}




\begin{tabular}{|c|c|c|c|c|}
\hline $\begin{array}{l}\text { Shuter et al., } \\
2001\end{array}$ & $\begin{array}{l}\text { To determine the prevalence } \\
\text { and predictive value of } \\
\text { overweight in an urban HIV } \\
\text { clinic. }\end{array}$ & $\begin{array}{l}189 \text { HIV+ } \\
\text { patients from } \\
\text { Jacobi Medical } \\
\text { Center HIV } \\
\text { Clinic }\end{array}$ & $\begin{array}{l}\text { Progression to } \\
\text { AIDS and CD4 } \\
\text { cell count }\end{array}$ & $\begin{array}{l}\text { Female gender and lack of AIDS diagnosis } \\
\text { were independently associated with } \\
\text { overweight. Among patients without AIDS, } \\
\text { there was a trend towards slower disease } \\
\text { progression and lower viral load in overweight } \\
\text { patients, despite similar baseline CD4 cell } \\
\text { count and similar time to initiation of HAART. } \\
\text { In multivariate proportional hazards analyses, } \\
\text { lower baseline BMI and falling BMI during } \\
\text { follow-up were independently predictive of } \\
\text { progression to AIDS. }\end{array}$ \\
\hline $\begin{array}{l}\text { Shor-Posner et } \\
\text { al, } 2000 \\
\text { Longitudinal } \\
\text { Prospective } \\
\text { Cohort Study }\end{array}$ & $\begin{array}{l}\text { To compare immune } \\
\text { measures and disease } \\
\text { progression in obese and } \\
\text { nonobese HIV-1- } \\
\text { seropositive men and women } \\
\text { in the pre-HAART era. }\end{array}$ & $\begin{array}{l}125 \text { HIV-1- } \\
\text { infected and } \\
148 \\
\text { seronegative } \\
\text { male and } \\
\text { female drug. }\end{array}$ & $\begin{array}{l}\text { HIV-1 related } \\
\text { mortality, CD4 } \\
\text { cell count }<200 \\
\text { cells/ } \mu \mathrm{L} \text { and } \\
25 \% \text { decline in } \\
\text { CD4 cell count }\end{array}$ & $\begin{array}{l}\text { Over an } 18-\text { month period, } 60.5 \% \text { of the } \\
\text { nonobese HIV-1-seropositive patients } \\
\text { exhibited a } 25 \% \text { decline in CD } 4 \text { cell count, } \\
\text { compared with } 18 \% \text { of the obese patients. } \\
\text { During the follow-up period, } 38 \% \text { of the lean } \\
\text { and } 13 \% \text { of the nonobese study subjects died } \\
\text { of HIV-1-related causes. Measurements of } \\
\text { BMI were inversely associated with } \\
\text { progression to death, independent of CD4 } \\
\text { count }<200 \text { cells } / \mathrm{mm} 3 \text {. }\end{array}$ \\
\hline
\end{tabular}


Table 2: Genetic Association Studies on the FTO Gene in African Populations

\begin{tabular}{|c|c|c|c|c|c|}
\hline $\begin{array}{l}\text { Author/Study } \\
\text { Design }\end{array}$ & Study Purpose & Population & $\begin{array}{l}\text { FTO SNPs } \\
\text { Analyzed }\end{array}$ & FTO Results with BMI & Other Results \\
\hline $\begin{array}{l}\text { Lombard et al., } \\
2012 \\
\text { Genetic } \\
\text { Association Study } \\
\text { (Cross-sectional) }\end{array}$ & $\begin{array}{l}\text { To assess the } \\
\text { association of } \\
\text { candidate loci with } \\
\text { BMI in black South } \\
\text { Africans. The } \\
\text { authors focused on } \\
\text { SNPs in the FTO, } \\
L E P, L E P R, M C 4 R \text {, } \\
\text { NPY } 2 R \text { and POMC } \\
\text { genes. }\end{array}$ & $\begin{array}{l}990 \text { randomly } \\
\text { selected adolescents } \\
\text { from } \\
\text { the larger Birth to } \\
\text { Twenty cohort (a } \\
\text { longitudinal birth } \\
\text { cohort study of health } \\
\text { and development in } \\
\text { Africans) born in the } \\
\text { metropolitan area of } \\
\text { Soweto, } \\
\text { Johannesburg, }\end{array}$ & $\begin{array}{l}\text { rs9939973 } \\
\text { rs9940128 } \\
\text { rs1421085 } \\
\text { rs1121980 } \\
\text { rs17817449 } \\
\text { rs8050136 } \\
\text { rs9939609 }\end{array}$ & $\begin{array}{l}\text { FTO rs } 17817449 \text {, the minor } \\
\text { allele ( } \mathrm{G} \text { in both cases) is } \\
\text { associated with increased } \\
\text { BMI. The seven FTO SNPs in } \\
\text { this study explain } 0.6 \% \text { of } \\
\text { variation in log(BMI) after } \\
\text { adjusting for age-, gender- } \\
\text { and sex-specific pubertal } \\
\text { stage and } 1.4 \% \text { unadjusted. } \\
\text { FTO rs } 17817449 \text { ( } p=0.022) \\
\text { associated with BMI after } \\
\text { adjustment for above factors. }\end{array}$ & $\begin{array}{l}\text { Sex, sex-specific } \\
\text { pubertal stage and } \\
\text { exact age together } \\
\text { explain } 14.3 \% \text { of } \\
\text { variation in log(BMI). } \\
\text { Each risk allele was } \\
\text { associated with an } \\
\text { estimated average } \\
\text { increase of } 2.5 \% \text { BMI. }\end{array}$ \\
\hline $\begin{array}{l}\text { Adeyemo et al., } \\
2010 \\
\text { Genetic } \\
\text { Association Study } \\
\text { (Cross-sectional) }\end{array}$ & $\begin{array}{l}\text { To evaluate genetic } \\
\text { variation in the FTO } \\
\text { gene and } \\
\text { investigate } \\
\text { associations with } \\
\text { obesity in West } \\
\text { Africans and African } \\
\text { Americans. }\end{array}$ & $\begin{array}{l}\text { Two independent } \\
\text { subsets: } \\
\text { 1) } 968 \text { unrelated } \\
\text { African Americans in } \\
\text { Washington, D.C., } \\
\text { and } \\
\text { 2) } 517 \text { unrelated West } \\
\text { Africans enrolled as } \\
\text { control subjects as } \\
\text { part of the Africa- } \\
\text { America Diabetes } \\
\text { Mellitus (AADM) } \\
\text { Study. }\end{array}$ & $\begin{array}{l}262 \text { tag single } \\
\text { nucleotide } \\
\text { polymorphisms } \\
\text { (SNPs) across } \\
\text { the entire gene. }\end{array}$ & $\begin{array}{l}\text { The combined effect size for } \\
\text { BMI for the top SNPs from } \\
\text { meta-analysis was } 0.77 \mathrm{~kg} / \mathrm{m}^{2} \\
(\mathrm{P}=0.009, \mathrm{rs} 9932411) \text { and } \\
0.70 \mathrm{~kg} / \mathrm{m}^{2}(\mathrm{P}=0.006, \\
\text { rs7191513). Two previously } \\
\text { reported associations with } \\
\text { intron } 1 \text { SNPs ( } \mathrm{rs} 1121980 \\
\left.\text { and rs7204609, } \mathrm{r}^{2}=0.001\right) \\
\text { were replicated among the } \\
\text { West Africans. }\end{array}$ & $\begin{array}{l}\text { Both African-ancestry } \\
\text { samples showed } \\
\text { weaker linkage } \\
\text { disequilibrium (LD) } \\
\text { patterns compared to } \\
\text { other continental (e.g., } \\
\text { European) populations. } \\
\text { Several intron } 8 \text { SNPs, } \\
\text { in addition to intron } 1 \\
\text { SNPs, showed } \\
\text { significant associations } \\
\text { in both study samples. }\end{array}$ \\
\hline Hennig et al., 2009 & $\begin{array}{l}\text { To assess the effect } \\
\text { of } 16 \text { FTO SNPs on }\end{array}$ & $\begin{array}{l}2208 \text { Lean Gambians } \\
\text { (Children and Adults) }\end{array}$ & rs6499642 & $\begin{array}{l}\text { FTO SNPs not associated } \\
\text { with birth weight (BWT), early }\end{array}$ & Not Applicable \\
\hline
\end{tabular}




\begin{tabular}{|c|c|c|c|}
\hline $\begin{array}{l}\text { Genetic } \\
\text { Association Study } \\
\text { (Cross-sectional) }\end{array}$ & $\begin{array}{l}\text { body mass in a } \\
\text { large population of } \\
\text { predominantly lean } \\
\text { Gambians } \\
\text { participating in a } \\
\text { long-term } \\
\text { surveillance } \\
\text { program providing } \\
\text { contemporary and } \\
\text { early-life } \\
\text { anthropometric } \\
\text { measurements. }\end{array}$ & $\begin{array}{l}\text { rs6499643 } \\
\text { rs7206790 } \\
\text { rs9940646 } \\
\text { rs12447107 } \\
\text { rs17817288 } \\
\text { rs16945088 } \\
\text { rs17817449 } \\
\text { rs8063946 } \\
\text { rs8063946 } \\
\text { rs3751812 } \\
\text { rs3751813 } \\
\text { rs9939609 } \\
\text { rs9931494 } \\
\text { rs7190492 } \\
\text { rs72046609 } \\
\text { rs9935403 }\end{array}$ & $\begin{array}{l}\text { weight gain in 1-2 year olds, } \\
\text { BMI in adults ( } \geq 18 \mathrm{y} \text { ), or } \\
\text { weight-for-height (WFH) z- } \\
\text { score across all ages. No } \\
\text { association was seen } \\
\text { between genotype and WFH } \\
\text { z-score or other measures of } \\
\text { body mass. }\end{array}$ \\
\hline
\end{tabular}


Table 3: Studies Conducted on Leptin and HIV Disease Progression in ART Naïve

\begin{tabular}{|c|c|c|c|c|}
\hline $\begin{array}{l}\text { Author/Study } \\
\text { Design }\end{array}$ & Study Purpose & Population & $\begin{array}{l}\text { Main } \\
\text { Outcome(s) }\end{array}$ & Study Findings \\
\hline $\begin{array}{l}\text { Azzoni et al., } \\
2010 \\
\text { Cross-sectional } \\
\text { Study }\end{array}$ & $\begin{array}{l}\text { To assess the } \\
\text { relationship of fat or } \\
\text { markers related to } \\
\text { glucose and lipid } \\
\text { metabolism with } \\
\text { viral load in a cross- } \\
\text { sectional sample of } \\
83 \text { ART-naïve HIV-1 } \\
\text { infected South } \\
\text { African women. }\end{array}$ & $\begin{array}{l}83 \text { ART naïve South African } \\
\text { women }\end{array}$ & $\begin{array}{l}\text { Cell activation, } \\
\text { innate } \\
\text { immunity } \\
\text { effector levels } \\
\text { and adipose } \\
\text { tissue-related } \\
\text { measures } \\
\text { including } \\
\text { leptin }\end{array}$ & $\begin{array}{l}\text { Women with viral load greater than the } \\
\text { population median had lower serum leptin. } \\
\text { Leptin levels were inversely associated with } \\
\text { viral replication, independent of the amount of } \\
\text { adipose tissue. }\end{array}$ \\
\hline $\begin{array}{l}\text { Onyemelukwe } \\
\text { et al., } 2009\end{array}$ & $\begin{array}{l}\text { To determine serum } \\
\text { leptin levels in ART } \\
\text { naïve HIV-1 infected } \\
\text { adults in relation to } \\
\text { BMI, CD4 cell count } \\
\text { and presence or } \\
\text { absence of } \\
\text { symptomatic HIV } \\
\text { disease or features } \\
\text { of AIDS. }\end{array}$ & $\begin{array}{l}40 \text { consecutive matched, } \\
\text { HIV infected adults ( } 20 \\
\text { normal weight and } 20 \\
\text { underweight) and } 26 \text { sex } \\
\text { matched HIV negative, } \\
\text { healthy normal weight } \\
\text { controls in Nigeria }\end{array}$ & Leptin & $\begin{array}{l}\text { Female patients tended to have lower leptin } \\
\text { than males. Median leptin was lower in } \\
\text { underweight when compared to normal weight } \\
\text { patients and also lower in symptomatic } \\
\text { patients when compared to asymptomatic } \\
\text { patients but not significantly different between } \\
\text { AIDS and non-AIDS cases. Among healthy } \\
\text { controls, leptin levels positively correlated with } \\
\text { CD4 T counts but in HIVIAIDS patients the } \\
\text { correlation was not significant. }\end{array}$ \\
\hline $\begin{array}{l}\text { Cross-sectional } \\
\text { Study }\end{array}$ & $\begin{array}{l}\text { To determine the } \\
\text { leptin levels in HIV } \\
\text { and HIV with active } \\
\text { pulmonary TB and } \\
\text { to see whether leptin } \\
\text { levels are altered } \\
\text { with co-infection. }\end{array}$ & $\begin{array}{l}20 \text { asymptomatic, ART } \\
\text { naïve HIV infected patients, } \\
20 \text { asymptomatic ART } \\
\text { naïve HIV infected patients } \\
\text { with TB, } \\
20 \text { healthy control subjects } \\
\text { (All participants from India) }\end{array}$ & Leptin & $\begin{array}{l}\text { Serum leptin levels and BMI were significantly } \\
\text { lower in the patients with HIV-TB than control } \\
\text { and HIV subjects. Multivariate regression } \\
\text { analysis showed that serum leptin was } \\
\text { significantly dependent on BMI and sex but } \\
\text { not on age and the disease groups. Leptin did } \\
\text { not correlated with either with CD4 cell count } \\
\text { so with any of the serum cytokines in HIV and } \\
\text { HIV-TB patients. }\end{array}$ \\
\hline
\end{tabular}


Table 4: Studies Conducted on C-Reactive Protein and HIV Disease Progression in ART Naïve

\begin{tabular}{|c|c|c|c|c|}
\hline $\begin{array}{l}\text { Author/Study } \\
\text { Design }\end{array}$ & Study Purpose & Population & $\begin{array}{l}\text { Main } \\
\text { Outcome(s) }\end{array}$ & Study Findings \\
\hline $\begin{array}{l}\text { Ledwaba L et al., } \\
2012 \\
\text { Nested Case- } \\
\text { Control Substudy }\end{array}$ & $\begin{array}{l}\text { To assess in an ART naïve } \\
\text { group of patients with } \\
\text { advanced HIV infection } \\
\text { whether pre-ART levels of } \\
\text { inflammatory and coagulation } \\
\text { biomarkers are associated } \\
\text { with mortality. In addition, to } \\
\text { assess whether initiation of } \\
\text { ART lowered levels of these } \\
\text { biomarkers, and compared } \\
\text { pre-ART biomarker levels } \\
\text { among patients with early } \\
\text { versus late HIV infection and } \\
\text { HIV uninfected patients. }\end{array}$ & $\begin{array}{l}187 \text { HIV infected } \\
\text { ART-naïve } \\
\text { patients with } \\
\text { CD4 cell count } \\
<200 \text { cells/ } \mu \mathrm{L} \\
\text { who died } \\
359 \text { HIV infected } \\
\text { ART-naïve } \\
\text { patients with } \\
\text { CD4 cell count } \\
<200 \text { cells/ } \mu \text { L } \\
\text { matched controls } \\
80 \text { uninfected } \\
\text { (South African } \\
\text { Cohort) }\end{array}$ & Mortality & $\begin{array}{l}\text { Median baseline biomarkers levels for cases } \\
\text { and controls, respectively, were } 11.25 \text { vs. } 3.6 \\
\text { mg/L for hsCRP, HIV viral load was } \\
\text { correlated with hsCRP. Adjusted odds ratios } \\
\text { for the highest versus lowest quartile of } \\
\text { baseline biomarker levels were } 3.5(95 \% \mathrm{Cl} \text { : } \\
\text { 1.9-6.7) for hsCRP, } 2.6(95 \% \mathrm{Cl} 1.4-4.9) \text { for } \\
\text { D-dimer, and } 3.8 \text { ( } 95 \% \mathrm{Cl}: 1.8-7.8) \text { for IL-6. } \\
\text { These associations were stronger for deaths } \\
\text { that occurred more proximal to the biomarker } \\
\text { measurements. Levels of D-dimer and IL-6, } \\
\text { but not hsCRP, were significantly lower at } \\
\text { month } 6 \text { after commencing ART compared to } \\
\text { baseline. }\end{array}$ \\
\hline $\begin{array}{l}\text { Retrospective } \\
\text { Longitudinal } \\
\text { Study }\end{array}$ & $\begin{array}{l}\text { To determine whether ART } \\
\text { initiation in ART naïve or } \\
\text { those off of ART ( } \geq 6 \text { months) } \\
\text { reduced markers of } \\
\text { inflammation. }\end{array}$ & $\begin{array}{l}254 \text { HIV+ ART } \\
\text { naïve or off of } \\
\text { ART ( } \geq 6 \text { months) } \\
\text { at baseline (126 } \\
\text { differed initiation } \\
\text { of ART (DC) and } \\
128 \text { had } \\
\text { immediate } \\
\text { initiation of ART } \\
\text { (VS) }\end{array}$ & $\begin{array}{l}\text { D-dimer, IL- } \\
\text { and CRP }\end{array}$ & $\begin{array}{l}\text { At month } 6,62 \% \text { of VS group had HIV RNA } \\
<400 \text { copies/mL and median CD4 count was } \\
190 \text { cells/mm3 higher than for the DC group } \\
\text { (590 vs. } 400 \text { cells/mm3). Compared with DC, } \\
\text { the VS group had } 32 \% \text { lower D-dimer levels } \\
\text { at month; differences were not significant for } \\
\text { hsCRP or IL-6 levels. }\end{array}$ \\
\hline $\begin{array}{l}\text { Chaudhary et al., } \\
2008\end{array}$ & $\begin{array}{l}\text { To elucidate association of } \\
\text { CRP with CD4 counts and } \\
\text { survival in HIV-1 infected }\end{array}$ & $\begin{array}{l}119 \text { HIV-infected } \\
\text { ART naïve } \\
\text { patients }\end{array}$ & $\begin{array}{l}\text { AIDS related } \\
\text { mortality and } \\
\text { CD4 cell count }\end{array}$ & $\begin{array}{l}\text { CRP was correlated with CD4 count and } \\
\text { mortality at } 1 \text { year. CRP was negatively } \\
\text { correlated with CD4 counts with levels of } \\
\text { CRP being highest in the group with CD4 cell }\end{array}$ \\
\hline
\end{tabular}




\begin{tabular}{|c|c|c|c|c|}
\hline $\begin{array}{l}\text { Prospective } \\
\text { Longitudinal } \\
\text { Study }\end{array}$ & individuals & $\begin{array}{l}33 \text { healthy } \\
\text { individuals }\end{array}$ & & $\begin{array}{l}\text { counts below } 200 \mathrm{cells} / \mu \mathrm{L} \text {. Higher CRP } \\
\text { category }(>12 \mathrm{mg} / \mathrm{dL} \text { ) was associated with } \\
\text { AIDS-related deaths in a Cox proportional } \\
\text { Hazard Model after adjusting for CD4 cell } \\
\text { count. }\end{array}$ \\
\hline $\begin{array}{l}\text { Guimaraes et al., } \\
2008 \\
\text { Cross-sectional } \\
\text { Study }\end{array}$ & $\begin{array}{l}\text { To compare hsCRP in HIV- } \\
\text { infected patients treated or } \\
\text { not with ART and to correlate } \\
\text { hsCRP levels with traditional } \\
\text { cardiovascular risk factors } \\
\text { and to factors related to the } \\
\text { HIV infection. }\end{array}$ & $\begin{array}{l}129 \mathrm{HIV}+\mathrm{ART}- \\
\text { treated } \\
42 \mathrm{HIV}+\mathrm{ART} \\
\text { naive }\end{array}$ & CRP & $\begin{array}{l}\text { hsCRP levels were higher in ARV-treated } \\
\text { compared to ARV-naive patients. Seventy- } \\
\text { two (56\%) ARV-treated patients and } \\
11(26 \%) \text { ARV-naive patients had hsCRP } \\
\text { concentrations > } 3 \text { mg/dl (high risk for } \\
\text { cardiovascular complications). No correlation } \\
\text { was found between hsCRP levels and CD4 } \\
\text { cell counts and HIV-viral load. Independent } \\
\text { factors associated with hsCRP levels were } \\
\text { therapy with current non-nucleoside reverse } \\
\text { transcriptase inhibitors (NNRTI), waist-to-hip } \\
\text { ratio, fasting glucose and glucose levels } 2 \text { h } \\
\text { after load in multivariate analysis model } 1 \\
\text { and current NNRTI therapy, protease } \\
\text { inhibitor therapy and cardiometabolic } \\
\text { syndrome in multivariate analysis model. }\end{array}$ \\
\hline $\begin{array}{l}\text { Retrospective } \\
\text { Longitudinal } \\
\text { Cohort Study }\end{array}$ & $\begin{array}{l}\text { To elucidate the relationship } \\
\text { between HIV disease and the } \\
\text { concentration of CRP. }\end{array}$ & $\begin{array}{l}513 \text { HIV } \\
\text { serpopostive } \\
\text { men randomly } \\
\text { chosen MACS } \\
\text { participatns ART } \\
\text { naïve at baseline }\end{array}$ & Time to AIDS & $\begin{array}{l}\text { The cross-sectional associations between } \\
\text { log10 } \\
\text { CRP were correlated inversely with CD4 } \\
\text { lymphocyte counts and directly with log10 } \\
\text { HIV RNA levels. Levels of CRP of more than } \\
2.3 \mathrm{mg} / \mathrm{L} \text { were associated with a decreased } \\
\text { time to the development of AIDS (relative } \\
\text { time to AIDS, compared with individuals with } \\
\text { CRP levels of } 1.2 \mathrm{mg} / \mathrm{L} \text { or less, which } \\
\text { remained significant after adjustment for } \\
\text { CD4 lymphocyte counts and HIV RNA and } \\
\text { hemoglobin concentrations. Levels of CRP }\end{array}$ \\
\hline
\end{tabular}




\begin{tabular}{|l|l|l|l|}
\hline & & & $\begin{array}{l}\text { significantly increased over time with mean } \\
\text { slopes of 8.5\% and 4.5\% per year for } \\
\text { individuals with and without progression to } \\
\text { AIDS, respectively. Individuals had a } \\
\text { geometric mean CRP level of 2.5 mg/L in the } \\
\text { 6-month interval before progression to AIDS, } \\
\text { which was an increase from a nadir of } 1.0 \\
\mathrm{mg} / \mathrm{L} \text { at } 6.5 \text { years before progression to } \\
\text { AIDS. }\end{array}$ \\
& & & \\
& & & \\
\hline
\end{tabular}

Table 5: Studies Conducted on LPS and HIV Disease Progression in ART Naïve

\begin{tabular}{|c|c|c|c|c|}
\hline $\begin{array}{l}\text { Author/Study } \\
\text { Design }\end{array}$ & Study Purpose & Population & Main Outcome(s) & Study Findings \\
\hline $\begin{array}{l}\text { Marchetti et al., } \\
2011 \\
\text { Retrospective } \\
\text { Longitudinal } \\
\text { Study }\end{array}$ & $\begin{array}{l}\text { To evaluate the role of } \\
\text { immune activation and } \\
\text { microbial translocation in HIV } \\
\text { infected ART naïve patients } \\
\text { with high CD4 cell count in the } \\
\text { first years of chronic infection } \\
\text { in predicting HIV disease } \\
\text { progression. Also, to cross- } \\
\text { sectionally evaluate the } \\
\text { correlations between markers } \\
\text { of immune activation, } \\
\text { microbial translocation, and } \\
\text { CD4 cell count and HIV } \\
\text { viraemia and their } \\
\text { modifications during untreated } \\
\text { infection. }\end{array}$ & $\begin{array}{l}379 \text { HIV+ } \\
\text { patients ART } \\
\text { naive with } \\
\text { CD4>200 cells/ } \\
\mu \mathrm{L}\end{array}$ & $\begin{array}{l}\text { AIDS defining } \\
\text { condition, death, } \\
\text { CD4 cell count of } \\
<200 \text { cells/ } \mu \mathrm{L} \text { or } \\
\text { start of ART }\end{array}$ & $\begin{array}{l}\text { A median of } 3.1 \text { years after the estimated } \\
\text { serconversion date median LPS marker } 110 \\
\text { pg/mL (IQR 75-215). LPS was the only } \\
\text { biomarker associated with primary composite } \\
\text { outcome independently of age, HIV-RNA and } \\
\text { CD4 RR=1.04 per } \log _{e} \text { higher, } 95 \% \mathrm{Cl}: 1.18- \\
1.66, p<0.001) \text {. }\end{array}$ \\
\hline Redd et al., 2009 & To examine the longitudinal & $107 \mathrm{HIV}+\mathrm{ART}$ & LPS, soluble & Multiple markers for microbial translocation \\
\hline
\end{tabular}




\begin{tabular}{|l|l|l|l|l|}
\hline & $\begin{array}{l}\text { relationship between microbial } \\
\text { translocation and circulatory } \\
\text { Retrospective } \\
\begin{array}{l}\text { Longitudinal } \\
\text { inflammatory cytokine }\end{array}\end{array}$ & $\begin{array}{l}\text { naïve Ugandan } \\
\text { patients and 24 } \\
\text { HIV uninfected } \\
\text { responses in a cohort of } \\
\text { people with varying rates of } \\
\text { HIV-1 disease progression in } \\
\text { Rakai, Uganda. }\end{array}$ & $\begin{array}{l}\text { CD14, LPS, } \\
\text { EndoCAb, LPS } \\
\text { binding protein } \\
\text { and inflammatory } \\
\text { cytokines }\end{array}$ & $\begin{array}{l}\text { (lipopolysaccharide, endotoxin antibody, and } \\
\text { SCD14) did not change significantly during }\end{array}$ \\
& & & $\begin{array}{l}\text { HIV-1 disease progression. Moreover, } \\
\text { circulating immunoreactive cytokine levels } \\
\text { either decreased or remained virtually } \\
\text { unchanged throughout disease progression. }\end{array}$ \\
\hline
\end{tabular}




\section{References}

1. Gruberg L, Weissman NJ, Waksman R, et al. The impact of obesity on the shortterm and long-term outcomes after percutaneous coronary intervention: the obesity paradox? J Am Coll Cardiol 2002;39:578-584.

2. Degoulet $\mathrm{P}$, Legrain $\mathrm{M}$, Réach I, et al. Mortality risk factors in patients treated by chronic hemodialysis. Report of the Diaphane collaborative study. Nephron 1982;31:103-110.

3. McAuley PA, Blair SN. Obesity paradoxes. J Sports Sci 2011;29:773-782.

4. Valentijn TM, Galal W, Tjeertes EK, Hoeks SE, Verhagen HJ, Stolker RJ. The obesity paradox in the surgical population. Surgeon 2013;11:169-176.

5. Romero-Corral A, Somers VK, Sierra-Johnson J, et al. Accuracy of body mass index in diagnosing obesity in the adult general population. Int $\mathrm{J}$ Obes (Lond) 2008;32:959-966.

6. Jacobs EJ, Newton CC, Wang Y, et al. Waist circumference and all-cause mortality in a large US cohort. Arch Intern Med 2010;170:1293-1301.

7. Festa A, D'Agostino R Jr, Williams $\mathrm{K}$, et al. The relation of body fat mass and distribution to markers of chronic inflammation. Int J Obes Relat Metab Disord 2001;25:1407-1415.

8. Panagiotakos DB, Pitsavos C, Yannakoulia M, Chrysohoou C, Stefanadis C. The implication of obesity and central fat on markers of chronic inflammation: the ATTICA study. Atherosclerosis 2005;183:308-315.

9. Haslem DW, James WP. Obesity. Lancet 2005;366:1197-1209.

10. Flegel WA, Baumstark MW, Weinstock C, Berg A, Northoff H. Prevention of endotoxin-induced monokine release by human lowand high-density lipoproteins and by apolipoprotein A-I. Infect Immun 1993;61:5140-5146.

11. Harris HW, Grunfeld C, Feingold KR, Rapp JH. Human very low density lipoproteins and chylomicrons can protect against endotoxininduced death in mice. J Clin Invest 1990;86:696-702.

12. Levine DM, Parker TS, Donelly TM, Walsh A, Rubin AL. In vivo protection against endotoxin by plasma high density lipoprotein. Proc Natl Acad Sci USA 1993;90:12040-12044.

13. Read TE, Grunfeld C, Kumwenda ZL, et al. Triglyceride-rich lipoproteins prevent septic death in rats. J Exp Med 1995;182:267-72.

14. Rauchhaus M, Coats AJ, Anker SD. The endotoxin-lipoprotein hypothesis. Lancet 2000;356:930-933. 
15. Wurfel MM, Kunitake ST, Lichenstein $\mathrm{H}$, Kane JP, Wright SD.

Lipopolysaccharide (LPS)-binding protein is carried on lipoproteins and acts as a cofactor in the neutralization of LPS. J Exp Med 1994;180:1025-1035.

16. O'Rahilly S, Farooqi IS. Human obesity as a heritable disorder of the central control of energy balance. Int J Obes (Lond) 2008;32:S55-S61.

17. Walker AR, Adam F, Walker BF. World pandemic of obesity: the situation in Southern African populations. Public Health 2001;115:368-372.

18. Onen CL. Epidemiology of ischaemic heart disease in sub-Saharan Africa. Cardiovasc J Afr 2013;24:34-42.

19. Letamo G. The Prevalence of, and Factors Associated with, Overweight and besity in Botswana. J Biosoc Sc 2011;43:75-84.

20. The World Health Organization, Overweight and Obesity Fact Sheet. Available at: http://www.who.int/mediacentre/factsheets/fs311/en/. Accessed August 5, 2014.

21. Crum-Cianflone N, Roediger MP, Eberly L, et al. Increasing Rates of Obesity among HIV-Infected Persons during the HIV Epidemic. PLoS ONE 2010;5: e10106.

22. Amorosa V, Synnestvedt M, Gross R, et al. A tale of 2 epidemics. The intersection between obesity and HIV infection in Philadelphia. J Acquir Immune Defic Syndr 2005;9:557-561.

23. Hodgson LM, Ghattas $\mathrm{H}$, Pritchitt $\mathrm{H}$, et al. Wasting and obesity in HIV outpatients. AIDS 2001;15:2341-2342.

24. Uthman OA. Prevalence and pattern of HIV-related malnutrition among women in sub-Saharan Africa: a meta-analysis of demographic health surveys. BMC Public Health 2008;8:226-233.

25. Popkin BM, Adair LS, Ng SW. Global nutrition transition and the pandemic of obesity in developing countries. Nutr Rev 2012;70:3-21.

26. Shor-Posner G, Campa A, Zhang G, et al. When obesity is desirable: a longitudinal study of the Miami HIV-1-infected drug abusers (MIDAS) cohort. J Acquir Immune Defic Syndr 2000;23:81-88.

27. Jones CY, Hogan JW, Snyder B, et al. Overweight and human immunodeficiency virus (HIV) progression in women: associations HIV disease progression and changes in body mass index in women in the HIV epidemiology research study cohort. Clin Infect Dis 2003;37:S69-80. 
28. Shuter J, Chang CJ, Klein RS. Prevalence and predictive value of overweight in an urban HIV care clinic. J Acquir Immune Defic Syndr 2001;26:291-297.

29. Adeyemi OM, Vibhakar S, Evans AT. Obesity and lymphocyte subsets in virologically suppressed HIV-infected patients. Metabolism 2009;58:1285-1287.

30. Crum-Cianflone NF, Roediger M, Eberly LE, et al. Impact of weight on immune cell counts among HIV-infected persons. Clin Vaccine Immunol 2011;18(6):940946. doi: 10.1128/CVI.00020-11.

31. Johnson KD, Cai B, Duffus W, et al. Longitudinal Association Between BMI at Diagnosis and HIV Disease Progression. AIDS Behav 2014;18:2249-2257. doi: 10.1007/s10461-014-0805-0.

32. Tate $\mathrm{T}$, Willig AL, Willig JH, et al. HIV infection and obesity: where did all the wasting go? Antivir Ther 2012;17:1281-1289. doi: 10.3851/IMP2348.

33. Carlson MG, Snead WL, Campbell PJ. Fuel and energy metabolism in fasting humans. Am J Clin Nutr 1994;60:29-36.

34. Chandra RK. Nutrition and the immune system: an introduction. Am J Clin Nutr 1997;66:460S-463S.

35. Melchior JC. Metabolic aspects of HIV associated wasting. Biomed Pharm 1997;51:455-460.

36. Gallagher D, Heymsfield SB, Heo M, Jebb SA, MurgatroydPR, Sakamoto Y. Healthy percentage body fat ranges: an approach for developing guidelines based on body massindex. Am J Clin Nutr 2000;72:694-701.

37. Seagle HM, Strain GW, Makris A, Reeves RS. Position of theAmerican Dietetic Association: weight management. J Am Diet Assoc 2009;109:330-346.

38. Hu F. Measurements of Adiposity and Body Composition. In: Hu F, ed. Obesity Epidemiology. New York City: Oxford University Press, 2008;53-83.

39. Pérez-Matute P, Pérez-Martínez L, Blanco JR, et al. Multiple frequency bioimpedance is an adequate tool to assess total and regional fat mass in HIVpositive patients but not to diagnose HIV-associated lipoatrophy: a pilot study. J Int AIDS Soc 2013;16:18609. doi: 10.7448/IAS.16.1.18609.

40. Carr A, Samaras K, Burton S, et al. A syndrome of peripheral lipodystrophy, hyperlipidaemia and insulin resistance in patients receiving HIV protease inhibitors. AIDS 1998;12:F51-F58.

41. Swanson B, Hershow R, Sha BE, Benson CA, Cohen M, Gunfeld C. Body Composition in HIV Infected Women. Nutrition 2000;16:1064-1068. 
42. Visnegarwala F, Raghavan SS, Mullin CM et al. Sex differences in the associations of HIV disease characteristics and body composition in antiretroviral-naive persons. Amer J Clin Nutr 2005;82:850-856.

43. Hamill MM, Ward KA, Pettifor JA, Norris SA, Prentice A. Bone mass, body composition and vitamin D status of ARV-naïve, urban, black South African women with HIV infection, stratified by CD4 count Osteoporos Int 2013;24:28552861.

44. Frayling TM, Timpson NJ, Weedon MN, et al. A common variant in the FTO gene is associated with body mass index and predisposes to childhood and adult obesity. Science 2007;316:889-894.

45. Scuteri A, Sanna S, Chen WM, et al. Genome-wide association scan shows genetic variants in the FTO gene are associated with obesity-related traits. PLoS Genet 2007;3:e115.

46. Dina C, Meyre D, Gallina S, et al. Variation in FTO contributes to childhood obesity and severe adult obesity. Nat Genet 2007;39:724-726.

47. van der Hoeven F. Programmed cell death is affected in the novel mouse mutant Fused toes (Ft). Development 1994;120:2601-2607.

48. Gerken T, Girard CA, Tung YC, et al. The obesity-associated FTO gene encodes a 2-oxoglutarate-dependent nucleic acid demethylase. Science 2007 30;318:1469-1472.

49. Fredriksson R, Hägglund M, Olszewski PK, et al. The obesity gene, FTO, is of ancient origin, up-regulated during food deprivation and expressed in neurons of feeding-related nuclei of the brain. Endocrinology 2008;149:2062-2071.

50. Wåhlén K, Sjölin E, Hoffstedt J. The common rs9939609 gene variant of the fat mass- and obesity-associated gene FTO is related to fat cell lipolysis. J Lipid Res 2008;49:607-611.

51. Kring SI, Holst C, Zimmermann E, et al. FTO gene associated fatness in relation to body fat distribution and metabolic traits throughout a broad range of fatness. PLoS ONE 2008;3:e2958.

52. Hennig BJ, Fulford AJ, Sirugo G, Rayco-Solon P, Hattersley AT, Frayling TM, Prentice AM. FTO gene variation and measures of body mass in an African population. BMC Med Genet 2009;10:21.

53. Adeyemo A, Chen G, Zhou J, Shriner D, Doumatey A, Huang H, Rotini C. FTO Genetic Variation and Association with Obesity in West Africans and African Americans. Diabetes 2010;59:1548-1554. 
54. Lombard Z, Crowther NJ, van der Merwe L, Pitamber P, Norris SA, Ramsay M. Appetite regulation genes are associated with body mass index in black South African adolescents: a genetic association study. BMJ Open 2012;2: e000873 doi:10.1136/bmjopen-2012-000873.

55. South African History Online: towards a people's history. Accessed August http://www.sahistory.org.za/people-south-africa/tswana

56. Hjort J. Pre-colonial culture, post-colonial economic success? The Tswana and the African economic miracle. Econ Hist Rev 2010;63:688-709.

57. Pineda-Tenor D, Berenguer J, Jiménez-Sousa MA, et al. FTO rs9939609 polymorphism is associated with metabolic disturbances and response to HCV therapy in HIV/HCV-coinfected patients. BMC Med 2014;12:198. doi: 10.1186/s12916-014-0198-y.

58. Tahergorabi Z, Khazaei M. The relationship between inflammatory markers, angiogenesis, and obesity. ARYA Atheroscler 2013;9:247-253.

59. Heilbronn LK, Campbell LV. Adipose tissue macrophages, low grade inflammation and insulin resistance in human obesity. Curr Pharm Des 2008;14:1225-1230.

60. Trayhurn P, Drevon CA, Eckel J. Secreted proteins from adipose tissue and skeletal muscle - adipokines, myokines and adipose/muscle cross-talk. Arch Physiol Biochem 2011;117:47-56.

61. Xu H, Barnes GT, Yang Q, et al. Chronic inflammation in fat plays a crucial role in the development of obesity-related insulin resistance. J Clin Invest 2003; 112:1821-1830.

62. HotamisligilGS,ShargillNS, SpiegelmanBM.Adipose expression of tumornecrosis factor- alpha:direct role in obesity-linked insulin resistance. Science 1993;259:8791.

63. Theofilopoulos AN,Baccala R, Beutler B,Kono DH.Type I interferons (alpha/beta) in immunity and autoimmunity. Annu Rev Immunol 2005;23:307-336.

64. Douek DC, Picker LJ, Koup RA. T cell dynamics in HIV-1 infection 14. Annu Rev Immunol 2003;21:265-304.

65. Alimonti JB, Ball TB, Fowke KR. Mechanisms of CD4+ T lymphocyte cell death in human immunodeficiency virus and AIDS. J Gen Virol 2003;84:1649-1661.

66. Ipp $\mathrm{H}$, Zemlin A. The paradox of the immune response in HIV infection: when inflammation becomes harmful. Clin Chim Acta 2013;416:96-99. 
67. Maeda K, Okubo K, Shimomura I, Mizuno K, Matsuzawa Y, Matsubara K. Analysis of an expression profile of genes in the human adipose tissue. Gene 1997;190:227-235.

68. Fain JN, Madan AK, Hiler ML, Cheema P, Bahouth SW. Comparison of the release of adipokines by adipose tissue, adipose tissue matrix, and adipocytes from visceral and subcutaneous abdominal adipose tissues of obese humans. Endocrinology 2004;145:2273-2282.

69. Singla P, Bardoloi A, Parkash AA. Metabolic effects of obesity: A review. World J Diabetes 2010;1:76-88.

70. Guzik TJ, Korbut R, Adamek-Guzik T. Nitric oxide and superoxide in inflammation and immune regulation. J Physiol Pharmacol 2003;54:469-487

71. Considine RV, Sinha MK, Heiman ML, et al. Serum imunorective-leptin concentrations in normal-weight and obese humans. N Engl J Med 1999;334:292-295.

72. Saad MF, Damani S, Gingerich RL, et al. Sexual dimorphism in plasma leptin concentration. J Clin Endocrinol Metab 1997;82:579-584.

73. Brann DW, De Sevilla L, Zamorano PL, Mahesh VB. Regulation of leptin gene expression and secretion by steroid hormones. Steroids 1999;64:659-663.

74. Wellen KE, Hotamisligil GS. Obesity-induced inflammatory changes in adipose tissue. J Clin Invest 2003;112:1785-1788.

75. Lord GM. Leptin as a Proinflammatory Cytokine. Contrib Nephrol 2006;151:151164.

76. Lin $\mathrm{Y}$, Lee $\mathrm{H}$, Berg AH, Lisanti MP, Shapiro L, Scherer PE. The lipopolysaccharide-activated Toll-like receptor (TLR)-4 induces synthesis of the closely related TLR-2 in adipocytes. J Biol Chem 2000;275:24255-24263.

77. Chen K, Li F, LI J, Cai H, Strom S, Bisello A, Kelley DE, Friedman-Einat M, Skibinski GA, McCrory MA, Szalai AJ, Zhao AZ. Induction of leptin resistance through direct interaction of C-reactive protein with leptin. Nat Med 2006;12:425432.

78. Wieland CW, Florquin S, Chan ED, et al. Pulmonary Mycobacterium tuberculosis infection in leptin-deficient ob/ob mice. Int Immunol 2005;17:1399-1408.

79. Fantuzzi G, Faggioni R. Leptin in the regulation of immunity, inflammation and hematopoiesis. J. Leukoc. Biol 2000;68:437-446.

80. Martin-Romero C, Santos-Alvarez J, Goberna R, Sanchez-Margalet V. Human leptin enhances activation and proliferation of human circulating $T$ lymphocytes. Cell. Immunol 2000;199:15-24. 
81. Shimabukuro M, Wang MY, Zhou YT, Newgard CB, Unger RH. Protection against lipoapoptosis of beta cells through leptin-dependent maintenance of Bcl2 expression. Proc Natl Acad Sci USA 1998;95:9558-9561.

82. Considine RV, Sinha MK, Heiman ML, et al. Serum immunoreactive-leptin concentrations in normal-weight and obese humans. N Engl J Med 1996;334:292-295.

83. Sweeney LL, Brennan AM, Mantzoros CS. The role of adipokines in relation to HIV lipodystrophy. AIDS 2007;21:895-904.

84. Brennan AM, Mantzoros CS. Drug insight: the role of leptin in human physiology and pathophysiology-emerging clinical applications. Nat Clin Pract Endocrinol Metab 2006;2:318-327.

85. Prabha C, Karthic S, Das SD, Swaminathan S, Subramaniam S, Sukumar B. Impact of Tuberculosis on Serum Leptin Levels in Patients with HIV infection. Horm Res. 2005;63:228-233.

86. Onyemelukwe GC, Ogoina D, Bakari AG. Serum Leptin Levels in Antitretroviral Therapy Naïve HIV-1 Infected Patients in Zaria, Nigeria. Int J Endocrinol Metab 2009;3:162-169.

87. Azzoni L, Crowther NJ, Firnhaber C, et al. Association between HIV replication and serum leptin levels: an observational study of a cohort of HIV-1-infected South African women. J Int AIDS Soc 2010;13:33.

88. Perseghin G, Lattuada G, De Cobelli F, et al. J Clin Endocrinol Metab 2007;92:4883-4888.

89. Zimmermann E, Skogstrand K, Hougaard DM, et al. Influences of the Common FTO rs9939609 Variant on Inflammatory Markers Throughout a Broad Range of Body Mass Index. PLoS ONE 2011;6: e15958.

90. Zabena C, Gonzalez-Sanchez JL, Martinez-Larrad MT, Torres-Garcia A. The FTO Obesity Gene. Genotyping and Gene Expression Analysis in Morbidly Obese Patients. Obes Surg 2009;19:87-95

91. Qi L, Kang K, Zhang C, van Dam RM, Kraft P, Hunter D, Lee CH, Hu FB. Fat mass-and obesity-associated (FTO) gene variant is associated with obesity: longitudinal analyses in two cohort studies and functional test. Diabetes 2008;57:3145-3151.

92. Terra X, Auguet T, Porras JA, et al. Anti-inflammatory profile of FTO gene expression in adipose tissues from morbidly obese women. Cell Physiol Biochem 2010;26:1041-1050. 
93. Ablij H, Meinders A. C-reactive protein: history and revival. Eur J Intern Med 2002;13:412.

94. Pepys M B, Hirschfield G M C-reactive protein: a critical update. J Clin Invest 2003;111:1805-1812.

95. Eckel R H, Grundy S M, Zimmet P Z The metabolic syndrome. Lancet 2005;365:1415-1428.

96. Pitsavos C, Panagiotakos DB, Tzima N, et al. Diet, exercise, and C-reactive protein levels in people with abdominal obesity: the ATTICA epidemiological study. Angiology 2007;58:225-233.

97. Pearson T A, Mensah G A, Alexander R W, et al Markers of inflammation and cardiovascular disease: application to clinical and public health practice: $A$ statement for healthcare professionals from the Centers for Disease Control and Prevention and the American Heart Association. Circulation 2003;107:499-511.

98. Pepys MB, Hirschfield GM. C-reactive protein: a critical update. J Clin Invest 2003;111:1805-1812.

99. Roberts WL, CDC. CDC/AHA Workshop on Markers of Inflammation and Cardiovascular Disease: Application to Clinical and Public Health Practice: laboratory tests available to assess inflammation--performance and standardization: a background paper. AHA Circulation 2004;110(25):e572-576.

100. Ramana KV1, Sabitha V, Rao R. A Study of Alternate Biomarkers in HIV Disease in Resource Poor Settings in Highly Active Antiretroviral Therapy (HAART) Era. J Clin Diagn Res 2013;7:1332-1335. doi: 10.7860/JCDR/2013/5306.3138.

101. Lau B, Sharrett AR, Kingsley LA, Post W, Palella FJ, Visscher B, Gange SJ. CReactive Protein Is a Marker for Human Immunodeficiency Virus Disease Progression. Arch Intern Med 2006;166:64-70.

102. Guimaraes MM, Greco DB, Figeredo SM, Foscolo RB, Oliveira AR, Machados LJ. High-sensitivity C-reactive protein levels in HIV-infected patients treated or not with antiretroviral drugs and their correlation with factors related to cardiovascular risk and HIV infection. Atherosclerosis 2008;201:434-439.

103. Chaudhary M, Kashyap B, Gautam H, Saini S, Bhalla P. Role of C-Reactive Protein in HIV Infection: A Pilot Study. Viral Immun 2008;21:263-266.

104. Baker JV, Neuhaus J, Duprez D, et al. Changes in inflammatory and coagulation biomarkers: a randomized comparison of immediate versus deferred antiretroviral therapy in patients with HIV infection. J Acquir Immune Defic Syndr 2011;56:36-43. 
105. Ledwaba L, Tavel JA, Khabo P, et al. Pre-ART levels of inflammation and coagulation markers are strong predictors of death in a South African cohort with advanced HIV disease. PLoS One 2012;7:e24243.

106. Maachi M, Piéroni L, Bruckert E, et al. Systemic low grade inflammation is related to both circulating and adipose tissue TNFa, leptin and IL-6 levels in obese women. Int J Obes 2004;28:993-997.

107. Fall T, Hägg S, Mägi R et al. The role of adiposity in cardiometabolic traits: a Mendelian randomization analysis. PLoS Med 2013;10:e1001474. doi: 10.1371/journal.pmed.1001474.

108. Fisher E, Schulze MB, Stefan N, et al. Association of the FTO rs9939609 single nucleotide polymorphism with C-reactive protein levels. Obesity (Silver Spring). 2009;17:330-334. doi: 10.1038/oby.2008.465.

109. Ziegler TR, Luo M, Estívariz CF, et al. Detectable serum flagellin and lipopolysaccharide and upregulated anti-flagellin and lipopolyssharide and upregulated anti-flagellin and lopolysaccharide immunoglobins in human short bowel syndrome. AM J Physiol Regul Integr Comp. Physiol 2008;294:R402R410.

110. Sandler NG, Douek DC. Microbial translocation in HIV infection: causes, consequences and treatment opportunities. Nat Rev Microbiol 2012;10:655-666.

111. Hunt PW, Brenchley J, Sinclair E, et al., Relationships between T cell activation and CD4 T cell count in HIV-seropositive individuals with undetectable plasma HIV RNA levels in the absence of therapy. J Infect Dis 2008;197:126-133.

112. Redd AD, Eaton KP, Kong X, et al. C-reactive protein levels increase during HIV1 disease progression in Rakai, Uganda, despite the absence of microbial translocation. J Acquir Immune Defic Syndr 2010;54(5):556-559.

113. Marchetti G, Cozzi-Lepri A, Merlini E, et al. Microbial translocation predicts disease progression of HIV-infected antiretroviral-naive patients with high CD4+ cell count. AIDS 2011;25:1385-1394.

114. Prevalence of HIV, total (\% of population ages 15-49). World Bank. Available at: http://data.worldbank.org/indicator/SH.DYN.AIDS.ZS. Accessed June 9, 2014. 


\title{
CHAPTER III: EFFECT OF BMI AND BODY COMPOSITION ON HIV DISEASE PROGRESSION IN HIV INFECTED ART NAÏVE ADULTS IN BOTSWANA
}

\begin{abstract}
Background: An obesity paradox has been documented in many conditions including HIV. Several studies indicate that overweight or obesity provides some protection from accelerated HIV disease progression in patients not receiving antiretroviral therapy (ART). Studies conducted to investigate obesity and its effect on HIV disease progression have been inconclusive and are lacking in African settings. This research investigates the relationship between overweight and obesity and HIV disease progression in HIV+ asymptomatic adults not on ART in Botswana over a period of 18 months.
\end{abstract}

Methods: A retrospective, cohort study in asymptomatic, ART naïve, HIV+ adults was conducted that included 217 participants, 139 with BMI $18.0-24.9 \mathrm{~kg} / \mathrm{m}^{2}$ and 78 participants with $\mathrm{BMI} \geq 25 \mathrm{~kg} / \mathrm{m}^{2}$. The primary outcome was time to event $(25 \%$ or greater decrease in CD4 cell count) during 18 months of follow-up and secondary outcomes were time to event of CD4 cell count $<250$ cells $/ \mu \mathrm{L}$, and AIDS defining conditions. Proportional survival hazard models were used to compare hazard ratios on time to events of HIV disease progression between BMI groups and BMI and body composition as continuous variables over 18 months.

Results: Using Cox Proportional Hazards model, higher baseline BMI was associated with significantly lower risk of having an AIDS defining condition over an 18 months follow-up $(\mathrm{HR}, 0.218 ; 95 \% \mathrm{Cl}, 0.068-0.701, \mathrm{P}=0.011)$. Higher fat mass at baseline was also significantly associated with a decreased risk of having AIDS defining conditions $(\mathrm{HR}, 0.855 ; 95 \% \mathrm{Cl}, 0.741-0.987, \mathrm{P}=0.033)$ and the combined outcome of having $\mathrm{CD} 4$ cell count $\leq 250 / \mu \mathrm{L}$ and AIDS defining conditions, whichever occurred earlier (HR, 0.918; 
95\% Cl: 0.847-0.994, $\mathrm{P}=0.036)$. All models were adjusted for age, gender, marital status, children (yes or no) and baseline CD4 cell count and baseline HIV viral load. There was no significant effect of BMI on HIV viral load over 18 months.

Conclusions: Higher BMI and fat mass were associated with slower disease progression in HIV infected ART naive adults in Botswana. Mechanistic research is needed to evaluate the association of obesity and HIV disease progression.

Keywords: HIV infection, ART naïve, BMI, disease progression, body composition, BIA 


\section{Introduction}

The importance of good nutrition in maintaining good health and delaying disease progression for the HIV patient has been well documented in the literature. ${ }^{1,2}$ At the beginning of the HIV epidemic, wasting was one of the main nutritionally related concerns, however, today rates of obesity are more common than the occurrence of wasting, particularly in developed countries, ${ }^{3-5}$ especially with antiretroviral treatment (ART). ${ }^{6}$

An obesity paradox has been documented in many conditions including HIV infection, where those who are obese may have a survival advantage or improved disease outcomes. ${ }^{7}$ The protective effect of obesity has been hypothesized to be related to extra available energy in the form of available fat for use in time of crisis during the HIV disease that would spare protein use ${ }^{8}$ and also help to preserve the immune system response. Studies on HIV and obesity were mainly conducted in settings where the patients are treated with ART, which may confound some of the findings and interpretations, as ART has been associated with lipodystrophy and obesity. ${ }^{5}$ Increased obesity has been documented in countries with limited resources, ${ }^{9}$ however, studies conducted in African settings on the relationship between HIV and obesity are lacking. It has been estimated that in sub-Saharan Africa, $10 \%$ of women have a BMI of less than $18.5 \mathrm{~kg} / \mathrm{m}^{2}$, with wasting still prevalent in some areas. ${ }^{10}$ However, sub-Saharan Africa is experiencing a nutrition-related transition with a rapid rise in overweight and obesity. ${ }^{11}$ Botswana is also experiencing an increase in obesity. ${ }^{12}$ Growth in economy, urbanization, and diminished physical activity is contributing to the rise in obesity in Southern Africa. ${ }^{13}$ Studies conducted to investigate obesity and its effect on HIV disease progression have so far been inconclusive, with some studies reporting an association and others reporting no association between CD4 cell counts and obesity. ${ }^{6,14-17}$ 
Botswana is also experiencing one of the worst epidemics of HIV with a prevalence rate of $23.4 \%$, among those in the range between 15 and 49 years of age in men and women. ${ }^{18}$ Botswana has been one of the first developing countries to provide universal access to ART. ${ }^{19}$ Currently, HIV+ adults in Botswana can receive ART once their CD4 cell counts are less than 500 cells/ $\mu \mathrm{L}$. Countries especially in sub-Saharan Africa are still having many challenges in providing ART and maintaining adherence. ${ }^{20}$ Therefore, $^{2}$ having information on delaying disease progression, and its relationships to nutritionrelated measures, in those regions where the two epidemics are co-occuring, is timely.

The objective of this study was to examine the relationship between overweight and obesity and HIV disease progression in HIV+ asymptomatic adults not on ART in Botswana over 18 months. The primary outcome was time to the first occurrence of a $25 \%$ or greater decrease in CD4 cell count during the course of the study and the secondary outcomes were time to reaching CD4 cell count $<250$ cells/ $\mu \mathrm{L}$, AIDS defining conditions, and changes in HIV viral load. This study was conducted in HIV+ adults who were ART naïve and had CD4 cell counts $>350$ cells $/ \mu \mathrm{L}$.

\section{Methods}

\section{Study Design and Participants}

A retrospective, cohort study analyzing data from $219 \mathrm{HIV}+$ men and women from the placebo group of a clinical trial in Botswana was conducted. This trial was a multifactorial, randomized, double-blinded, placebo-controlled clinical trial which investigated whether supplementation with multivitamins and selenium could improve immune function and prolong time to AIDS in ART naïve HIV+ adults. ${ }^{21}$ The study was conducted between December 2004 and July 2009. The placebo group was used to avoid any confounding effects from the micronutrient supplementation on the outcome measures. Participants were eligible for the parent study with documentation of HIV 
seropositive test results, CD4 cell count was $>350$ cells $/ \mu \mathrm{L}$, BMI was $>18 \mathrm{~kg} / \mathrm{m}^{2}$ for women and $18.5 \mathrm{~kg} / \mathrm{m}^{2}$ for men, age $\geq 18$ years, lack of a past history of AIDS-defining conditions, participation in another clinical trial and taking ART. Women were excluded if pregnant or had intention to become pregnant. All participants provided informed consent and were recruited from the Botswana-Harvard AIDS Initiative Partnership $(\mathrm{BHP})$ in Gaborone, Botswana. The study protocol was approved by the Florida International University Institutional Review Board (IRB), the Harvard School of Public Health IRB and the Botswana Health Research Unit of the National Ministry of Health. Appropriate informed consent was obtained and clinical research was conducted in accordance with guidelines for human experimentation as specified by the US Department of Health and Human Services, the researchers' institutions, or both.

\section{Clinical Data}

At baseline and every three months, physical examination and medical history were performed by a trained nurse or a physician. Anthropometrics were also obtained and body mass index (BMI) was calculated by dividing the weight in kilograms by height in meters squared. Waist and hip circumference was measured using a tape measure. Waist circumference was measured at the narrowest part of the waist between the lowest rib and the iliac crest and the hip circumference at the widest portion of the buttocks. Bioelectrical impedance analysis (BIA) using the Biodynamics body composition analyzer (model BIA-310; Biodynamics Corp., Seattle, WA), determined impedance and calculated body composition. Subjects were measured without shoes and socks, and electrodes were placed on the participant's right hand and wrist and right foot and ankle. Blood pressure was measured in the left arm with the elbow flexed to heart level. Morbidity information including AIDS-defining conditions, were collected by 
questionnaires at screening, and at every monthly visit, and confirmed by documentation in the medical chart.

\section{Laboratory Data}

At baseline and every three months blood was drawn for CD4 and CD8 cell counts. Every six months, blood was also drawn to evaluate HIV viral load, lipid panel, and blood chemistry. Lymphocyte phenotype was determined with a four-color immunophenotyping panel of monoclonal antibodies. Differential counts were determined using a Coulter MaxM hematology instrument and corroborated with cytocentrifuge smears. HIV-viral load was determined using an in-vitro nucleic acid amplification test (Amplicor reagents and protocol, Roche-Diagnostics, Branchburg, NJ). The lipid panel was measured using Roche reagent kits (Branchburg, NJ) on a COBAS Integra 400 plus auto-analyzer using enzymatic methods according to standard operating procedures.

\section{Nutritional Data}

Twenty-four hour recalls were conducted at baseline and every 3 months by trained clinical staff. Macronutrient and fiber intakes were calculated using the NutriBase Professional, V.9 (Cybersoft, Phoenix, AZ) program modified by the South Africa database, including native foods for which information was available. An average of at least 3 dietary recalls were used to obtain their estimated energy, carbohydrate, protein, fat and fiber intakes.

\section{Statistical Analysis}

BMI was stratified into two groups: 1. normal weight $\left(B M I=18.0-24.9 \mathrm{~kg} / \mathrm{m}^{2}\right)$ and 2. overweight/obese $\left(\mathrm{BMI} \geq 25 \mathrm{~kg} / \mathrm{m}^{2}\right)$. The overweight and obese BMl categories were combined to increase the sample size for the analyses. Laboratory markers of HIV infection and disease progression included in the analyses were CD4 cell count, CD4\%, 
CD8 cell count, CD8\%, CD4/CD8 ratio and HIV viral load. Descriptive statistics such as frequencies, percentages, medians and interquartile ranges were used to characterize the total population, the two groups stratified by BMI and the study variables (primary and secondary outcomes) at baseline. Mann Whitney $U$ and Chi-square tests were used to determine differences in HIV disease progression markers and markers of nutritional status between the BMI groups and by gender. Linear and logistic regressions at baseline and 18 months were conducted to observe the relationship between BMI and HIV disease progression and body composition measures from BIA using BMI as a continuous variable and dichotomous variable. The multiple regression analysis also included a measure to check for multicollinearity known as variance inflation factor (VIF). All models had a VIF $<5$, therefore multicollinearity was not a problem. Proportional survival hazard models were used to compare hazard ratios on time to events of HIV disease progression outcomes with BMI groups, BMl as a continuous variable and body composition over 18 months. The primary outcome was time to the first occurrence of a $25 \%$ or greater decrease in CD4 cell count during the course of the study and secondary outcomes were time to CD4 cell count $<250$ cells/ $\mu \mathrm{L}$, and AIDS defining conditions. These events were documented from the time of inclusion into the study to the date of the visit in which the event was recorded. All models were adjusted for covariates. For all analyses, a two sided test was used and $P<0.05$ was considered statistically significant. Statistical analyses were completed using SPSS version 21.

\section{Results}

\section{Demographics and Clinical Characteristics}

A total of 219 participants were assigned randomly into a placebo group by the parent study. ${ }^{21}$ Two participants had missing data and were excluded from the final analysis. Seventy-eight participants at baseline had BMI $\geq 25 \mathrm{~kg} / \mathrm{m}^{2}$ and 139 had 
$\mathrm{BMI}=18.0-24.9 \mathrm{~kg} / \mathrm{m}^{2}$. BMls were stable throughout the 18 months of follow-up and did not statistically change within the normal and overweight/obese groups (Table 1). Most of the participants were female $(75.1 \%)$ with a median age of 33 years, reflecting the characteristics of the epidemic in Botswana. ${ }^{22}$ Almost half $(45.2 \%)$ of the participants had at least a secondary education level and most had children (85.7\%).

There were differences in demographic factors among the BMI groups. Those with $\mathrm{BMI} \geq 25 \mathrm{~kg} / \mathrm{m}^{2}$ were older and more likely female, married and have children (Table 1). There were no differences in laboratory markers of HIV infection at baseline between the BMI groups. As shown on Table 2 , those with $\mathrm{BMI} \geq 25 \mathrm{~kg} / \mathrm{m}^{2}$ had a larger waist circumference and higher levels of total cholesterol, triglycerides, LDL cholesterol, glucose, and blood pressure. Albumin levels were higher in those with BMI 18-24.9 $\mathrm{kg} / \mathrm{m}^{2}$. Dietary intake was statistically different between the BMI groups. The overweight/obese group had higher basal metabolic rate and fat mass, but lower lean body mass, body cell mass and extracellular mass. Physical activity was not statistically different between the BMI groups (data not shown).

\section{Correlations between Laboratory Markers of HIV Infection and Body Composition}

BMI was significantly correlated with measures of body composition but not with the markers of HIV infection (Table 4). Waist circumference was associated with CD4\% $(\mathrm{r}=-.17, P<.05)$ and CD4/CD8 ratio $(\mathrm{r}=-.19, P=.05)$. Waist-to-hip ratio showed a correlation with CD4\% (-.33, $p<0.01)$, CD8 cell count $(r=.22, P<.01)$, and CD4/CD8 ratio $(r=-.26, P<.01)$. Both fat mass and lean mass were associated with CD4 cell count $(r=-$ $.14, r=.14, P<.05$, respectively).

\section{Effect of BMI on Laboratory Markers of HIV Infection and Disease Progression}

Table 5 displays the results from logistic regression analysis that compared the BMI groups at baseline, 18 months and the change over 18 months in the laboratory 
markers of HIV infection and disease progression. No significant associations were found with viral load, CD4 cell count, CD4\%, CD8 cell count, CD8\%, and CD4/CD8 ratio. However, there was a trend where CD4\% showed those with BMI $\geq 25 \mathrm{~kg} / \mathrm{m}^{2}$ to be more likely to have a higher change in CD4\% over 18 months $(\mathrm{OR}=1.076,95 \% \mathrm{Cl}=.988,1.166$, $P=.077$ ). All models were controlled for age, gender, marital status, and children (whether they had children, yes or no).

Linear regressions using $\mathrm{BMI}$ as a continuous variable were also conducted to compare with measures of HIV disease progression at baseline, 18 months, and the change over 18 months (Table 6). There was a trend in the association between CD8 cell count and BMI at 18 months $(\beta=.002,95 \% \mathrm{Cl}=.000, .004, P=.082)$. The change in CD4\% between baseline and 18 months was significantly associated with BMI, showing that for every unit increase in BMI there was .214 increase in the difference in CD4\% $(\beta=.214,95 \% \mathrm{Cl}=.051, .376, P=0.011)$. All models were adjusted for age, gender, marriage and children. No significant differences were found with CD4 cell count, CD8\%, and CD4/CD8 ratio.

Table 7 shows that after controlling for age, gender, marital status, children, baseline CD4 cell count and viral load, there were no significant differences between BMI groups in the main outcome of $25 \%$ decline in CD4 cell count over 18 months (HR= $.744 ; 95 \% \mathrm{Cl}=.489,1.131 ; P=.166)$. No significant differences were also observed in the secondary outcomes of CD4 cell count $\leq 250 / \mu \mathrm{L}$, AIDS defining conditions, or the combined outcome of CD4 cell count $\leq 250 / \mu \mathrm{L}$, AIDS defining conditions, whichever occurred first. As shown in Table 8, using continuous baseline BMI, higher BMI was associated with a protective effect on the risk of having an AIDS defining condition (HR= $.218 ; 95 \% \mathrm{Cl}=.068, .781 ; P=.011)$ after adjusting for age, gender, marriage, children and baseline CD4 cell count and viral load. Significant associations were not found 
between continuous BMI and CD4 cell count $\leq 250 / \mu \mathrm{L}$, AIDS defining conditions and the combined outcome of CD4 cell count $\leq 250 / \mu \mathrm{L}$, AIDS defining conditions, whichever occurred first.

\section{Effect of Body Composition on Laboratory Markers of HIV Infection and Disease Progression}

There were no significant associations using linear regression between measures of HIV disease progression and fat mass, lean body mass, and body cell mass at baseline, 18 months and the difference between these visits (Table 5).

A trend towards significance was seen with the outcome of $25 \%$ decline in CD4 cell count and fat mass $(\mathrm{HR}=.974 ; 95 \% \mathrm{Cl}=.945,1.003, P=.083)($ Table 9$)$. Higher fat mass was protective of having an AIDS defining condition $(\mathrm{HR}=.855 ; 95 \% \mathrm{Cl}=.741$, $.987 ; P=.033)$. Higher fat mass was protective against the combined outcome of CD4 cell count $\leq 250 / \mu \mathrm{L}$ and AIDS defining conditions, whichever occurred first $(H R=.918$; $95 \% \mathrm{Cl}=.847, .994 ; P=.036)$. The effect of lean body mass on disease progression was similar to fat mass, as shown on Table 10. As lean body mass increased there was a higher risk of having $\geq 25 \%$ decline in CD4 cell count during the 18 months of follow-up but was trending towards significance $(\mathrm{HR}=1.027 ; 95 \% \mathrm{Cl}=.997,1.059, P=.082)$. Higher lean body mass was associated with higher risk of having an AIDS defining condition $(\mathrm{HR}=1.169,95 \% \mathrm{Cl}=1.013,1.349 ; P=.033)$, and higher risk of CD4 cell count $\leq 250 / \mu \mathrm{L}$ and $\mathrm{AIDS}$ defining condition albeit not significant $(\mathrm{HR}=1.075 ; 95 \% \mathrm{Cl}=.995$, $1.161 ; P=.068)$. These models were also adjusted for age, gender, marital status, having children and baseline CD4 count and viral load.

\section{Discussion}

This study showed that BMI and fat mass were protective by delaying the time to the first AIDS defining condition in HIV+ ART naïve adults in Botswana during 18 months 
of follow-up. The fat stores would have provided the extra energy needed to maintain the innate immune system responding to protect against opportunistic infections and delaying wasting. There were no significant findings over 18 months when comparing the main outcome of a clinically significant decline of CD4 cell count (25\%) and BMI stratified into two groups, $\mathrm{BMI}=18.0-24.9 \mathrm{~kg} / \mathrm{m}^{2}$ and $\mathrm{BMI} \geq 25 \mathrm{~kg} / \mathrm{m}^{2}$. This finding suggests that the protective effect of fat stores are not enough to counteract the focused viral attack to the specific immune response, a suggestion supported by the results that show no association between BMI and HIV viral load. Shor-Posner et al. ${ }^{17}$ found a significant difference between obese and nonobese when comparing clinically significant $25 \%$ decline in CD4 cell count over 18 months. However, these participants were drug users and may have been in worse nutritional status and have had HIV for longer duration and were in more advanced stage. BMI at baseline as a continuous variable was associated with $78 \%$ lower risk of having an AIDS defining condition for every one unit increase in BMI. Past incidence of $>1$ AIDS defining condition was associated with 1.3 fold higher risk of having $\mathrm{BMI}<20 \mathrm{~kg} / \mathrm{m}^{2}$ and AIDS defining conditions were also associated with a higher risk of wasting. ${ }^{23}$

Higher BMI was also associated with a higher CD4\% after 18 months of followup. CD4\% is considered to be more steady than absolute CD4 cell counts and provide a better prognostic information before ART is initiated. ${ }^{24,25}$ Recently, it was shown to be a good predictor of disease progression for those starting ART with a CD4 cell count of $>350$ cells $/ \mu \mathrm{L} .{ }^{26}$ Other investigators have also found that immune counts are affected by weight and/or BMI in HIV. ${ }^{14,27}$ In a cross-sectional study ${ }^{14}$ with patients on ART, an absolute increase of 16 units of CD8 cell count was seen for every $1 \mathrm{~kg} / \mathrm{m}^{2}$ increase of in BMI. Crum-Cianflone and colleagues ${ }^{27}$ compared normal weight to obese HIV+ adults at diagnosis and through HAART or ART initiation and concluded that those who were 
obese had smaller reductions in CD4\% through time, regardless of whether diagnosis took place in the pre-HAART era or after. They also found similar results with CD4/CD8 counts and only significant differences between normal weight and overweight in the HAART era with CD8 counts. Our findings in ART-naïve population, early in HIV disease showed that there were no significant effects of BMI with CD4/CD8 or CD8 cell count. Interestingly, Crum-Cianflone and colleagues ${ }^{27}$ also showed that weight did not have an effect on immune cells at HIV diagnosis, but instead the effect of weight on immune cells was seen as the disease progressed. This study also did not have any significant differences at baseline between the normal weight and overweight/obese groups, because the great majority started their participation early in the disease at diagnosis.

This is the first study that demonstrated a longitudinal association between reduced AIDS defining conditions with higher fat mass. Higher fat mass was also associated with the combined outcome of CD4 cell count $\leq 250 / \mu \mathrm{L}$ and AIDS defining conditions. On the outcome of a decline in the CD4 cell count of $25 \%$ or greater, the survival analysis showed a positive trend association with fat mass and negative association with lean body mass, a finding supported by cross-sectional significant findings in our larger $(\mathrm{N}=878)$ cohort in Botswana. ${ }^{28}$ Supporting this relationship over time, Visnegarwala and colleagues ${ }^{29}$ demonstrated in a cross-sectional study that women with a prior AIDS defining condition had lower total body fat in kilograms. Maintaining a large lean mass has higher energy costs. Stored protein is less available than dietary protein and provides less energy than the same weight in fat, ${ }^{30}$ this might be one of the reasons why lean mass was not protective, but might be even counterproductive to maintain adequate immune response before ART. 
Findings from this study indicate that higher fat mass may provide protection from advanced HIV disease. This protective effect has been hypothesized to be related to extra available energy for use in times of emergency during the HIV disease that would reduce protein's use ${ }^{8}$ and also help to preserve the immune system, especially the innate immunity that is not directly affected by the infection. ${ }^{16,31}$ HIV and its secondary infections are known to generate a hypermetabolic state that is sustained throughout the disease. ${ }^{32}$ The HIV patient is susceptible to infections, in which the body will require energy to battle continuous infections and immune activation. Those who are obese may have a genetic advantage in maintaining fat stores and utilizing that energy more efficiently to fuel the immune system.

Although there seems to be an obesity paradox in HIV, being obese is a risk factor for mortality and chronic conditions or diseases such as cardiovascular diseases, diabetes, hypertension, and cancer. ${ }^{33-36}$ The participants of this study in the overweight/obese group had higher levels of total cholesterol, triglycerides, glucose, although not clinically significant, and higher LDL and blood pressure. These differences could over a period of time potentially increase their risks for chronic conditions.

Evidence from the literature supports that once a patient receives ART, their cardiovascular and liver risks increases, and obesity becomes an adverse factor for health and survival. ${ }^{5}$ Stevens and colleagues ${ }^{37}$ have stated concerns over providing confusing messages when discussing the obesity paradox and the possible harm it will have on public health efforts related to reducing obesity rates to lower the risk of chronic diseases. Conversely, other researchers ${ }^{38}$ theorize that our view of normal or optimal weight or BMI categories are too strict and may be biologically unsuitable. They also argue that those with an established disease diagnosis may benefit from an emphasis 
on lifestyle recommendations regarding physical activity and nutrition rather than intentional weight loss or gain.

The limitations of this study include the sample size, not having sufficient numbers of participants to be able to examine differences between overweight and obese groups separately, and the predominance of women among the participants. The exact time since HIV diagnosis was not available, however, it was known that the participants were asymptomatic, never had a diagnosis of AIDS and did not qualify for ART. The majority were referred from the clinics where they were diagnosed. Participants with BMI in the range of underweight category were not included in the parent study as those ranges are strong prognostic indicators of AIDS. ${ }^{21}$ This HIV population was in the early stage of the disease in order to study ART naïve individuals and the finding cannot be generalized to all HIV seropositive patients. The early stage of disease may be one of the reasons why we did not see a significant decline of CD4 as a main outcome. In HIV, bioimpedance (BIA) has been shown to be an effective method for detecting fat mass, ${ }^{39}$ however, BIA have limitations, since its values can be influenced by body arrangement, hydration, ingestion of food and drinks, air and body temperature and exercise. ${ }^{40}$ Our BIA measurement protocol provided for these limitations by giving detailed instructions to the participants on their preparation for their visit, and standardizing the measurement parameters. The strengths of this study consists of capturing and analyzing longitudinal data from HIV+ participants in Botswana, that we collected from early asymptomatic stage through defined health outcomes, and that this type of information is lacking in African populations.

In summary, the results of this study demonstrate that higher BMI and fat mass were protective in delaying HIV disease progression in this group of HIV+, ART naïve adults in Botswana. BMI separated into two groups, normal weight and 
overweight/obese groups, did not show a significant effect on decline of CD4 cell count over 18 months and may have been due to limited sample size and to the participants' early stage of the disease. Mechanistic studies on the relationship between BMI and body composition on disease progression are needed to clarify the obesity paradox in HIV.

\section{Acknowledgements}

This study was funded by the National Institute on Drug Abuse (R01-DA-016551). We thank all of the participants in the study without whom advancement in the nutritional management of the HIV disease would not have been possible. 
Table 1: Change in $\mathrm{BMI}^{*}$ from Baseline to 18 Months by BMI Groups

\begin{tabular}{llll}
\hline Groups & Baseline BMI & 18 Months BMI & $P$-value \\
\hline Overall & $22.8(20.7-27.2)$ & $24.1(20.4-27.2)$ & .511 \\
Normal BMI & $21.2(19.9-22.6)$ & $20.9(19.3-22.5)$ & .338 \\
Overweight/Obese & $28.5(26.6-30.1)$ & $28.1(26.1-30.4)$ & .466 \\
\hline
\end{tabular}

${ }^{*}$ Reported as median (interquartile range); BMI expressed as $\mathrm{kg} / \mathrm{m}^{2}$ 
Table 2: Demographic Characteristics by BMI Group at Baseline

\begin{tabular}{|c|c|c|c|c|}
\hline Variable & $\begin{array}{c}\text { Total } \\
(\mathrm{N}=217)\end{array}$ & $\begin{array}{l}\text { Normal BMI } \\
(\mathrm{N}=139)\end{array}$ & $\begin{array}{c}\text { Overweight/ } \\
\text { Obese BMI } \\
(\mathrm{N}=78)\end{array}$ & $\begin{array}{c}P- \\
\text { value }\end{array}$ \\
\hline Age (years) ${ }^{a}$ & $33(28-39)$ & $31(28-38)$ & $35(30-43)$ & $.005^{b}$ \\
\hline \multicolumn{5}{|l|}{ Gender } \\
\hline Male & $54(24.9)$ & $44(31.7)$ & $10(12.8)$ & \multirow[t]{2}{*}{$.002^{b}$} \\
\hline Female & $163(75.1)$ & $95(68.3)$ & 68 (87.2) & \\
\hline \multicolumn{5}{|l|}{ Marital Status } \\
\hline Single & $124(59.0)$ & $86(65.2)$ & $38(48.7)$ & \multirow[t]{3}{*}{$.010^{\mathrm{b}}$} \\
\hline Married & $24(11.4)$ & $9(6.8)$ & 15 (19.2) & \\
\hline Other & 62 (29.5) & $37(28.0)$ & $25(32.1)$ & \\
\hline \multicolumn{5}{|l|}{ Education } \\
\hline None & $13(6.2)$ & $9(6.8)$ & $4(5.1)$ & \multirow[t]{4}{*}{.984} \\
\hline Primary & $83(39.5)$ & $52(39.4)$ & $31(39.7)$ & \\
\hline Secondary & $95(45.2)$ & $59(44.7)$ & $36(46.2)$ & \\
\hline Tertiary & $19(9.0)$ & $12(9.1)$ & $7(9.0)$ & \\
\hline \multicolumn{5}{|l|}{ Income (pula) } \\
\hline None & $48(22.9)$ & $31(23.5)$ & $17(21.8)$ & \multirow[t]{7}{*}{.849} \\
\hline$<300$ & $20(9.5)$ & $12(9.1)$ & $8(10.3)$ & \\
\hline $300-600$ & $41(19.5)$ & $26(19.7)$ & $15(19.2)$ & \\
\hline $601-1000$ & $51(24.3)$ & $33(25.0)$ & $18(23.1)$ & \\
\hline $1001-6000$ & 43 (20.3) & 27 (20.5) & $16(20.5)$ & \\
\hline$>6000$ & $6(2.9)$ & $2(1.5)$ & $4(5.1)$ & \\
\hline Unsure & $1(0.5)$ & $1(0.8)$ & $0(0.0)$ & \\
\hline \multicolumn{5}{|l|}{ Electricity } \\
\hline Yes & $83(39.5)$ & $49(37.1)$ & $34(43.6)$ & \multirow[t]{2}{*}{.354} \\
\hline No & $127(60.5)$ & $83(62.9)$ & $44(56.4)$ & \\
\hline \multicolumn{5}{|l|}{ Children } \\
\hline Yes & $180(85.7)$ & $107(81.1)$ & 73 (93.6) & \multirow[t]{2}{*}{$<.001^{b}$} \\
\hline No & $30(14.3)$ & $25(18.9)$ & $5(6.4)$ & \\
\hline BMI $\left(\mathrm{kg} / \mathrm{m}^{2}\right)^{\mathrm{a}}$ & $22.8(20.7-27.2)$ & $21.2(19.9-22.6)$ & $28.5(26.6-30.1)$ & $.012^{b}$ \\
\hline $\begin{array}{l}\text { CD4 Cell Count } \\
(\text { cells } / \mu \mathrm{L})^{\mathrm{a}}\end{array}$ & $\begin{array}{c}411.3(326.3- \\
546.7)\end{array}$ & $\begin{array}{c}415.9(324.7- \\
548.9)\end{array}$ & $\begin{array}{c}401.2(331.2- \\
545.2)\end{array}$ & .908 \\
\hline $\begin{array}{l}\text { CD8 Cell Count } \\
(\text { cells } / \mu \mathrm{L})^{\mathrm{a}}\end{array}$ & $\begin{array}{c}838.6(617.5- \\
1194.9)\end{array}$ & $\begin{array}{c}804.1(588.8- \\
1229.0)\end{array}$ & $\begin{array}{c}891.3(669.0- \\
1177.8)\end{array}$ & .251 \\
\hline CD4/CD8 Ratio ${ }^{a}$ & $0.5(0.3-0.7)$ & $0.5(0.4-0.7)$ & $0.5(0.3-0.7)$ & .375 \\
\hline $\begin{array}{l}\text { HIV Viral Load } \\
\left(\log _{10} \text { copies } / \mathrm{mL}\right)^{a}\end{array}$ & $4.3(3.5-4.8)$ & $4.3(3.6-4.8)$ & $4.2(3.3-4.8)$ & .525 \\
\hline
\end{tabular}


Table 3: Nutrition Related Characteristics by BMI Group at Baseline

\begin{tabular}{|c|c|c|c|c|}
\hline Variable $^{a}$ & $\begin{array}{c}\text { Total } \\
(\mathrm{N}=217)\end{array}$ & $\begin{array}{c}\text { Normal BMI } \\
(\mathrm{N}=139)\end{array}$ & $\begin{array}{c}\text { Overweight/Obes } \\
\text { e BMI }(\mathrm{N}=78)\end{array}$ & $\begin{array}{c}P- \\
\text { value }\end{array}$ \\
\hline Waist (inches) & $32.3(29.9-35.7)$ & $30.7(29.1-32.3)$ & $37.6(34.8-39.3)$ & $<.001^{b}$ \\
\hline Waist-to-hip Ratio & $0.8(0.8-0.9)$ & $0.8(0.8-0.9)$ & $0.8(0.8-0.9)$ & $.017^{\mathrm{b}}$ \\
\hline $\begin{array}{l}\text { Total Cholesterol } \\
(\mathrm{mmol} / \mathrm{L})\end{array}$ & $3.7(3.0-4.3)$ & $3.5(2.9-4.0)$ & $4.0(3.5-4.7)$ & $<.001^{b}$ \\
\hline $\begin{array}{l}\text { Triglycerides } \\
(\mathrm{mmol} / \mathrm{L})\end{array}$ & $0.8(0.6-1.0)$ & $0.7(0.5-0.9)$ & $0.8(0.6-1.2)$ & $<.001^{\mathrm{b}}$ \\
\hline $\mathrm{HDL}(\mathrm{mmol} / \mathrm{L})$ & $1.1(0.9-1.3)$ & $1.1(0.9-1.4)$ & $1.1(0.9-1.2)$ & .301 \\
\hline LDL (mmol/L) & $2.4(2.0-2.9)$ & $2.4(1.8-2.7)$ & $2.6(2.2-3.0)$ & $.043^{b}$ \\
\hline Glucose (mmol/L) & $4.5(4.3-4.8)$ & $4.5(4.2-4.7)$ & $4.6(4.4-5.1)$ & $.002^{b}$ \\
\hline Hemoglobin (g/dL) & $12.9(11.8-14.0)$ & $12.7(11.4-14.1)$ & $13.0(12.2-14.0)$ & .251 \\
\hline Hematocrit $(\%)$ & $39.4(36.3-42.3)$ & $39.0(35.4-42.6)$ & $40.0(37.3-4.9)$ & .359 \\
\hline Albumin (g/L) & $41.0(39.3-43.4)$ & $41.6(39.0-44.5)$ & $39.8(37.7-42.6)$ & $.010^{b}$ \\
\hline Iron ( $\mu \mathrm{mol} / \mathrm{L})$ & $9.3(6.3-13.0)$ & $9.5(6.0-13.2)$ & $8.8(6.6-12.7)$ & .959 \\
\hline $\begin{array}{l}\text { Systolic Blood } \\
\text { Pressure }(\mathrm{mm} \mathrm{Hg})\end{array}$ & $119(110-130)$ & $114(108-128)$ & $122(111-139)$ & $<.001^{\mathrm{b}}$ \\
\hline $\begin{array}{l}\text { Diastolic Blood } \\
\text { Pressure }(\mathrm{mm} \mathrm{Hg})\end{array}$ & $76(69-82)$ & $72(65-80)$ & $80(70-88)$ & $<.001^{b}$ \\
\hline $\begin{array}{l}\text { Total Energy Intake } \\
\text { (kcal) }\end{array}$ & $\begin{array}{c}1507.1(1177.5- \\
1902)\end{array}$ & $\begin{array}{c}1496.4(1178.6- \\
1933.2)\end{array}$ & $\begin{array}{c}1568.0(1175.6- \\
1890.7)\end{array}$ & .749 \\
\hline Protein Intake (\%) & $16.3(14.0-19.6)$ & $16.9(14.1-20.7)$ & $15.9(14.0-18.6)$ & .959 \\
\hline $\begin{array}{l}\text { Carbohydrate } \\
\text { Intake (\%) }\end{array}$ & $65.6(57.1-71.8)$ & $65.6(57.3-71.4)$ & $65.9(56.6-72.7)$ & .202 \\
\hline Fat Intake (\%) & $17.4(12.4-22.9)$ & $17.4(12.1-22.8)$ & $17.4(12.7-23.2)$ & .524 \\
\hline $\begin{array}{l}\text { Fiber Intake } \\
\text { (grams) }\end{array}$ & $16.0(12.0-21.6)$ & $16.1(12.1-21.4)$ & $15.6(11.8-22.2)$ & .871 \\
\hline $\begin{array}{l}\text { Basal Metabolic } \\
\text { Rate (kcal) }\end{array}$ & $\begin{array}{c}1401(1268- \\
1564)\end{array}$ & $\begin{array}{c}1338(1209- \\
1498)\end{array}$ & $1532(1382-1696)$ & $<.001^{b}$ \\
\hline Fat Mass (\%) & $29.0(23.9-33.9)$ & 25.1 (19.9-29.3 & $34.9(32.5-37.9)$ & $<.001^{\mathrm{b}}$ \\
\hline Lean Mass (\%) & $71.0(66.1-76.1)$ & $74.9(70.6-80.1)$ & $65.1(62.1-67.5)$ & $<.001^{\mathrm{b}}$ \\
\hline Body Cell Mass (\%) & 34.1 (31.6-37.3) & $35.9(33.4-39.5)$ & $31.2(30 .-33.2)$ & $<.001^{\mathrm{b}}$ \\
\hline $\begin{array}{l}\text { Extracellular Mass } \\
(\%)\end{array}$ & $36.8(33.7-40.0)$ & $38.9(36.2-41.0)$ & $33.3(31.8-35.4)$ & $<.001^{\mathrm{b}}$ \\
\hline
\end{tabular}


Table 4: Spearman Correlation Coefficients at Baseline

\begin{tabular}{|c|c|c|c|c|c|c|c|c|c|c|c|}
\hline & BMI & Waist & $\begin{array}{l}\text { Waist } \\
\text {-to- } \\
\text { hip }\end{array}$ & $\begin{array}{c}\text { Fat } \\
\text { mass }\end{array}$ & $\begin{array}{l}\text { Lean } \\
\text { mass }\end{array}$ & $\begin{array}{c}\text { CD4 } \\
\text { cell } \\
\text { count }\end{array}$ & CD4\% & $\begin{array}{c}\text { CD8 } \\
\text { cell } \\
\text { count }\end{array}$ & $\begin{array}{c}\text { CD8 } \\
\%\end{array}$ & $\begin{array}{l}\text { CD4/ } \\
\text { CD8 } \\
\text { ratio }\end{array}$ & $\begin{array}{l}\text { Viral } \\
\text { Load }\end{array}$ \\
\hline $\mathrm{BMI}$ & 1.00 & & & & & & & & & & \\
\hline Waist & $.82^{* *}$ & 1.00 & & & & & & & & & \\
\hline Waist-to-hip & $.16^{*}$ & $.53^{* *}$ & 1.00 & & & & & & & & \\
\hline Fat mass & $.72^{* *}$ & $.58^{* *}$ & .03 & 1.00 & & & & & & & \\
\hline Lean mass & $-.72^{* *}$ & $-.58^{* *}$ & .03 & $-1.00^{* *}$ & 1.00 & & & & & & \\
\hline $\begin{array}{l}\text { CD4 cell } \\
\text { count }\end{array}$ & -.03 & -.08 & -.04 & $-.14^{*}$ & $.14^{*}$ & 1.00 & & & & & \\
\hline CD4\% & -.09 & $-.24^{* *}$ & $-.32^{* *}$ & -.08 & .08 & $.50^{* *}$ & 1.00 & & & & \\
\hline $\begin{array}{l}\text { CD8 cell } \\
\text { count }\end{array}$ & .06 & .14 & $.22^{* *}$ & -.03 & .03 & $.26^{* *}$ & $-.61^{* *}$ & 1.00 & & & \\
\hline CD8\% & -.05 & .04 & .11 & -.01 & .01 & $.29^{* *}$ & $.72^{* *}$ & $.73^{* *}$ & 1.00 & & \\
\hline $\begin{array}{c}\text { CD4/ } \\
\text { CD8 ratio }\end{array}$ & -.05 & $-.19^{*}$ & $-.26^{* *}$ & -.06 & .06 & $.44^{* *}$ & $.94^{* *}$ & $-.71^{* *}$ & $-.89^{* *}$ & 1.00 & \\
\hline Viral load & -.08 & -.06 & .10 & -.02 & .02 & $-.23^{* *}$ & $-.40^{* *}$ & $.29^{* *}$ & $.42^{* *}$ & $-.43^{* *}$ & 1.00 \\
\hline
\end{tabular}


Table 5: Logistic Regression at Baseline, 18 Months and the Change Over 18 Months by BMI Groups*

\begin{tabular}{|c|c|c|c|c|c|c|c|c|c|}
\hline \multicolumn{3}{|c|}{ Baseline } & \multicolumn{4}{|c|}{18 Months } & \multicolumn{3}{|c|}{ Change Over 18 Months } \\
\hline Variable & OR & $95 \% \mathrm{Cl}$ & $\mathrm{P}$-value & OR & $95 \% \mathrm{Cl}$ & $\mathrm{P}$-value & OR & $95 \% \mathrm{Cl}$ & P-value \\
\hline CD4 cell count & 1.000 & $.999,1.002$ & .603 & 1.000 & $.999,1.002$ & .640 & 1.001 & $.998,1.004$ & .399 \\
\hline CD4\% & .984 & $.946,1.024$ & .424 & .994 & 1.038 & .783 & 1.076 & 1.166 & .077 \\
\hline CD8 cell count & 1.000 & $.999,1001$ & .966 & 1.000 & $1.000,1.001$ & .433 & 1.000 & $1.000,1.001$ & .381 \\
\hline CD8\% & .991 & $.964,1.019$ & .536 & .993 & $.962,1.026$ & .691 & .976 & $.910, \quad 1.046$ & .486 \\
\hline CD4/CD8 ratio & .767 & $.286,2.056$ & .598 & .554 & 2.215 & .554 & .781 & 1.983 & .603 \\
\hline HIV viral load & 1.054 & $.748,1.485$ & .764 & .886 & 1.330 & .558 & .900 & 1.561 & .707 \\
\hline
\end{tabular}

${ }^{*}$ Dependent variable = BMI groups; reference category $=\mathrm{BMI} \geq 25 \mathrm{~kg} / \mathrm{m}^{2}$; Individual models analyzed for each independent variable and adjusted for age, gender, marriage, and children.

Table 6: Linear Regression at Baseline, 18 Months and the Change Over 18 Months by Continuous BMI ${ }^{* a}$

\begin{tabular}{|c|c|c|c|c|c|c|c|c|c|}
\hline \multicolumn{3}{|c|}{ Baseline } & \multicolumn{4}{|c|}{18 Months } & \multicolumn{3}{|c|}{ Change Over 18 Months } \\
\hline Variable & Slope & $95 \% \mathrm{Cl}$ & P-value & Slope & $95 \% \mathrm{Cl}$ & P-value & Slope & $95 \% \mathrm{Cl}$ & P-value \\
\hline CD4 cell count & .001 & -.002 & .469 & .003 & $-.002, \quad .008$ & .240 & -.004 & $-.010, \quad .002$ & .165 \\
\hline CD4\% & -.036 & -.116 & .371 & .052 & $-.063, .168$ & .374 & .214 & $.051, \quad .376$ & $.011^{\mathrm{b}}$ \\
\hline CD8 cell count & $<.001$ & -.001 & .938 & .002 & $.000, \quad .004$ & .082 & .001 & $-.001, \quad .002$ & .399 \\
\hline CD8\% & -.031 & -.087 & .270 & -.069 & $-.155, \quad .017$ & .116 & -.076 & $-.225, .073$ & .371 \\
\hline CD4/CD8 ratio & -.818 & $-2.878,1.243$ & .435 & -3.258 & $-7.323, .807$ & .115 & -.673 & $-2.613,1.266$ & .494 \\
\hline HIV viral load & .007 & $-.715, \quad .728$ & .986 & .204 & $-.789,1.196$ & .686 & .625 & $-.609,1.859$ & .318 \\
\hline
\end{tabular}

*Individual models analyzed for each independent variable and adjusted for age, gender, marriage, and children

${ }^{a}$ Dependent variable for baseline analysis included continuous BMI at baseline, dependent variable for 18 months analysis included continuous BMI at 18 months, and dependent variable for difference between visits analysis included continuous BMI at baseline.

${ }^{\mathrm{b}}$ Statistically significant, $P<.05$ 
Table 7: Adjusted Hazard Ratios on the Effect of BMI Groups on HIV Disease Progression Outcomes in HIV+ Adults in Botswana During a Follow-up Period of 18 Months*

\begin{tabular}{llll}
\hline Outcome & $\mathrm{HR}^{\mathrm{b}}$ & $95 \% \mathrm{Cl}^{\mathrm{c}}$ & $P$-value \\
\hline$\geq 25 \%$ decline in CD4 cell count & .744 & $.489,1.131$ & .166 \\
CD4 cell count $\leq 250 / \mu \mathrm{L}$ & 1.021 & $.381,2.740$ & .966 \\
AIDS Defining Conditions & .500 & $.047,4.465$ & .500 \\
CD4 cell count $\leq 250 / \mu \mathrm{L} \&$ AIDS & 1.089 & $.453,2.619$ & .849 \\
Defining Conditions & & &
\end{tabular}

${ }^{*}$ Cox proportional hazards model were used to examine the effect of BMI groups $(0=\mathrm{BM}$ $18.0-24.9 \mathrm{~kg} / \mathrm{m}^{2}$ and $1=\mathrm{BMI} \geq 25 \mathrm{~kg} / \mathrm{m}^{2}$ ) on individual HIV disease progression outcomes. All individual HIV disease progression outcomes were analyzed as separate models and adjusted for age, gender, marriage, children and baseline CD4 count and viral load.

a Statistically significant, $P<.05$

bHR= Hazard Ratio

${ }^{\mathrm{C}} \mathrm{Cl}=$ Confidence Interval

Table 8: Adjusted Hazard Ratios on the Effect of Baseline BMI on HIV Disease Progression Outcomes in HIV+ Adults in Botswana During a Follow-up Period of 18 Months*

\begin{tabular}{llll}
\hline Outcome & $\mathrm{HR}^{\mathrm{b}}$ & $95 \% \mathrm{Cl}^{\mathrm{c}}$ & $P$-value \\
\hline$\geq 25 \%$ decline in CD4 cell count & .963 & $.919,1.009$ & .113 \\
CD4 cell count $\leq 250 / \mu \mathrm{L}$ & 1.043 & $.932,1.167$ & .462 \\
AIDS Defining Conditions & .218 & $.068, .701$ & $.011^{\mathrm{a}}$ \\
CD4 cell count $\leq 250 / \mu \mathrm{L}$ \& AIDS & .904 & $.796,1.028$ & .124 \\
Defining Conditions & & &
\end{tabular}

${ }^{*}$ Cox proportional hazards model were used to examine the effect of baseline continuous $\mathrm{BMI}$ on individual HIV disease progression outcomes. All individual HIV disease progression outcomes were analyzed as separate models and adjusted for age, gender, marriage, children and baseline CD4 count and viral load.

** Model adjusted for age, gender, children and baseline CD4 cell count and viral load

astatistically significant, $P<.05$

${ }^{\mathrm{b}} \mathrm{HR}=$ Hazard Ratio

${ }^{\mathrm{C}} \mathrm{Cl}=$ Confidence Interval 
Table 9: Adjusted Hazard Ratios on the Effect of Baseline Fat Mass on HIV Disease Progression Outcomes in HIV+ Adults in Botswana During a Follow-up Period of 18 Months*

\begin{tabular}{llll}
\hline Outcome & $\mathrm{HR}^{\mathrm{b}}$ & $95 \% \mathrm{Cl}^{\mathrm{c}}$ & $P$-value \\
\hline$\geq 25 \%$ decline in CD4 cell count & .974 & $.945,1.003$ & .083 \\
CD4 cell count $\leq 250 / \mu \mathrm{L}$ & .984 & $.909,1.065$ & .793 \\
AIDS Defining Conditions & .855 & $.741, .987$ & $.033^{\mathrm{a}}$ \\
CD4 cell count $\leq 250 / \mu \mathrm{L} \&$ AIDS & .918 & $.847, .994$ & $.036^{\mathrm{a}}$ \\
Defining Conditions & & &
\end{tabular}

${ }^{*}$ Cox proportional hazards model were used to examine the effect of baseline continuous fat mass \% on individual HIV disease progression outcomes. All individual HIV disease progression outcomes were analyzed as separate models and adjusted for age, gender, marriage, children and baseline CD4 count and viral load.

a Statistically significant, $P<.05$

${ }^{\mathrm{b}} \mathrm{HR}=$ Hazard Ratio

${ }^{\mathrm{C}} \mathrm{Cl}=$ Confidence Interval

Table 10: Adjusted Hazard Ratios on the Effect of Baseline Lean Mass on HIV Disease Progression Outcomes in HIV+ Adults in Botswana During a Follow-up Period of 18 Months*

\begin{tabular}{llll}
\hline Outcome & $\mathrm{HR}^{\mathrm{b}}$ & $95 \% \mathrm{Cl}^{\mathrm{c}}$ & $P$-value \\
\hline$\geq 25 \%$ decline in CD4 cell count & 1.027 & $.997,1.059$ & .082 \\
CD4 cell count $\leq 250 / \mu \mathrm{L}$ & 1.008 & $.939,1.100$ & .692 \\
AIDS Defining Conditions & 1.169 & $1.013,1.349$ & $.033^{\mathrm{a}}$ \\
CD4 cell count $\leq 250 / \mu \mathrm{L}$ \& AIDS & 1.075 & $.995,1.161$ & .068 \\
Defining Conditions & & & \\
\hline
\end{tabular}

${ }^{*}$ Cox proportional hazards model were used to examine the effect of baseline continuous lean mass \% on individual HIV disease progression outcomes. All individual HIV disease progression outcomes were analyzed as separate models and adjusted for age, gender, marriage, children and baseline CD4 count and viral load.

${ }^{a}$ Statistically significant, $P<.05$

${ }^{\mathrm{b}} \mathrm{HR}=$ Hazard Ratio

${ }^{\mathrm{C}} \mathrm{Cl}=$ Confidence Interval 


\section{References}

1. Fields-Gardner C, Campa A; American Dietetics Association. Position of the American Dietetic Association: Nutrition Intervention and Human Immunodeficiency Virus Infection. J Am Diet Assoc 2010;110:1105-1119.

2. Polsky B, Kotler D, Steinhart C. HIV-associated wasting in the HAART era. Guidelines for assessment, diagnosis, and treatment. AIDS Patient Care 2001;15:411-423.

3. Amorosa V, Synnestvedt M, Gross R, Friedman H, MacGregor RR, et al. A tale of epidemics. The intersection between obesity and HIV infection in Philadelphia. J Acquir Immune Defic Syndr 2005;9:557-561.

4. Hodgson LM, Ghattas $\mathrm{H}$, Pritchitt $\mathrm{H}$, et al. Wasting and obesity in HIV outpatients. AIDS 2001;15:2341-2342.

5. Mankal PK, Kotler DP. From Wasting to Obesity, Changes in Nutritional Concerns in HIVIAIDS. Endocrinol Metab Clin North Am 2014;43:647-663. doi: 10.1016/j.ecl.2014.05.004.

6. Crum-Cianflone N, Roediger MP, Eberly L, Headd M, et al. Increasing Rates of Obesity among HIV-Infected Persons during the HIV Epidemic. PLoS ONE 2010;5: e10106.

7. McAuley PA, Blair SN. Obesity paradoxes. J Sports Sci. 2011;29:773-782.

8. Carlson MG, Snead WL, Campbell PJ. Fuel and energy metabolism in fasting humans. Am J Clin Nutr 1994;60:29-36.

9. Gersh BJ, Sliwa K, Mayosi BM, Yusuf S. Novel therapeutic concepts: the epidemic of cardiovascular disease in the developing world: global implications. Eur Heart J 2010;31:642-648. doi: 10.1093/eurheartj/ehq030.

10. Uthman OA. Prevalence and pattern of HIV-related malnutrition among women in sub Saharan Africa: a meta-analysis of demographic health surveys. BMC Public Health 2008;8:226-233.

11. Popkin BM, Adair LS, Ng SW. Global nutrition transition and the pandemic of obesity In developing countries. Nutr Rev 2012;70:3-21.

12. Letamo G. The Prevalence of, and Factors Associated with, Overweight and Obesity in Botswana. J Biosoc Sc 2011;43:75-84.

13. Walker AR, Adam F, Walker BF. World pandemic of obesity: the situation in Southern African populations. Public Health 2001;115:368-372.

14. Adeyemi OM, Vibhakar S, Evans AT. Obesity and lymphocyte subsets in virologically suppressed HIV-infected patients. Metabolism 2009;58:1285-1287. 
15. Jones CY, Hogan JW, Snyder B, et al. Overweight and human immunodeficiency virus (HIV) progression in women: associations HIV disease progression and changes in body mass index in women in the HIV epidemiology research study cohort. Clin Infect Dis 2003;37:S69-80.

16. Shuter J, Chang CJ, Klein RS. Prevalence and predictive value of overweight in an urban HIV care clinic. J Acquir Immune Defic Syndr 2001;26:291-297.

17. Shor-Posner G, Campa A, Zhang G, et al. When obesity is desirable: a longitudinal study of the Miami HIV-1-infected drug abusers (MIDAS) cohort. J Acquir Immune Defic Syndr 2000;23:81-88.

18. Prevalence of HIV, total (\% of population ages 15-49). World Bank. Available at: http://data.worldbank.org/inidicator/SH.DYN>AIDS.ZS. Accessed November 22, 2013.

19. Bussmann H, Wester CW, Thomas A, et al. Response to zidovudine/didanosinecontaining combination antiretroviral therapy among HIV-1 subtype C-infected adults in Botswana: two-year outcomes from a randomized clinical trial. J Acquir Immune Defic Syndr 2009;51:37-46.

20. De Cock KM, El-Sadr WM. When to start ART in Africa: an urgent research priority. N Engl J Med 2013;368:886-889. doi:10.1056 /NEJMp1300458.

21. Baum MK, Campa A, Lai S, et al. Effect of micronutrient supplementation on disease progression in asymptomatic, antiretroviral-naive, HIV-infected adults in Botswana: a randomized clinical trial. JAMA 2013;310:2154-2163.

22. UNAIDS. (2010). NACA Botswana-2010 country progress report. Retrieved September 10, 2014 from http://www.unaids.ort/en/countryresponses/countries/bostwana.asp

23. Wanke CA, Silva M, Ganda A, et al. Role of acquired immune deficiency syndrome-defining conditions in human immunodeficiency virus-associated wasting. Clin Infect Dis 2003;37:S81-S84.

24. Taylor JM, Fahey JL, Detels R, Giorgi JV. CD4 percentage, CD4 number, and CD4:CD8 ratio in HIV infection: which to choose and how to use. J Acquir Immune Defic Syndr 1989;2:114-124.

25. Burcham J, Marmor M, Dubin N, et al. CD4\% is the best predictor of development of AIDS in a cohort of HIV-infected homosexual men. AIDS 1991; 5:365-372.

26. Hulgan T, Raffanti S, Kheshti A, et al. CD4 lymphocyte percentage predicts disease progression in HIV-infected patients initiating highly active antiretroviral therapy with CD4 lymphocyte counts $>350$ lymphocytes $/ \mathrm{mm}^{3}$. J Infect Dis. 2005; 192:950957. 
27. Crum-Cianflone NF, Roediger M, Eberly LE, et al. Impact of weight on immune cell counts among HIV-infected persons. Clin Vaccine Immunol 2011;18:940-6. doi: 10.1128/CVI.00020-11.

28. Riedel P, Ramamoorthy V, Baum MK, et al. Protein intake is associated with HIV disease progression in HIV-infected patients. Experimental Biology 2014 Conference, San Diego, CA, April 26-30, 2014.

29. Visnegarwala F, Raghavan SS, Mullin CM et al. Sex differences in the associations of HIV disease characteristics and body composition in antiretroviral-naive persons. Amer J Clin Nutr. 2005;82:850-856.

30. Berdanier, Carolyn D. CRC Desk Reference for Nutrition. Boca Raton, FL: CRC Press;1998.

31. Chandra RK. Nutrition and the immune system: an introduction. Am J Clin Nutr 1997;66:460S-463S.

32. Melchior JC. Metabolic aspects of HIV associated wasting. Biomed Pharm 1997;51:455-460.

33. McGee DL; Diverse Populations Collaboration. Body mass index and mortality: a meta-analysis based on person-level data from twenty-six observational studies. Ann Epidemiol 2005;15:87-97.

34. Bogers RP, Bemelmans WJ, Hoogenveen RT, et al. Association of overweight with increased risk of coronary heart disease partly independent of blood pressure and cholesterol levels: a meta-analysis of 21 cohort studies including more than 300000 persons. Arch Intern Med 2007;167:1720-1728.

35. Sullivan PW, Morrato EH, Ghushchyan V, Wyatt HR, Hill JO. Obesity, inactivity, and the prevalence of diabetes and diabetes-related cardiovascular comorbidities in the U.S., 2000-2002. Diabetes Care 2005;28:1599-1603.

36. Calle EE, Rodriguez C, Walker-Thurmond K, Thun MJ. Overweight, obesity, and mortality from cancer in a prospectively studied cohort of U.S. adults. N Engl J Med 2003;348:1625-1638.

37. Stevens J, Bradshaw PT, Truesdale KP, Jensen MD. Obesity Paradox should not interfere with public health efforts. Int J Obes (Lond) 2014. doi: 10.1038/ijo.2014.60.

38. Dixon JB, Egger GJ, Finkelstein EA, Kral JG, Lambert GW. 'Obesity paradox' misunderstands the biology of optimal weight throughout the life cycle. Int J Obes (Lond) 2014. doi: 10.1038/ijo.2014.59.

39. Pérez-Matute P, Pérez-Martínez L, Blanco JR, et al. Multiple frequency bioimpedance is an adequate tool to assess total and regional fat mass in HIV- 
positive patients but not to diagnose HIV-associated lipoatrophy: a pilot study. J Int AIDS Soc 2013;16:18609. doi: 10.7448/IAS.16.1.18609.

40. Bioelectrical impedance analysis in body composition measurement: National Institutes of Health Technology Assessment Conference Statement. Am J Clin Nutr 1996;64:524S-532S. 


\title{
CHAPTER IV: PRELIMINARY ASSOCIATION STUDY OF THE FAT MASS AND OBESITY ASSOCIATED GENE POLYMORPHISMS WITH HIV DISEASE PROGRESSION
}

\begin{abstract}
Objective: Being overweight or obese in HIV has been shown to be protective in delaying disease progression. The objective of this study was to assess whether polymorphisms of the fat mass and obesity associated gene (FTO) are associated with body composition and HIV disease progression in HIV+, ART naïve adults in Botswana. Methods: A retrospective study was completed with 215 participants from the placebo group of a randomized controlled trial previously conducted and published. Five SNPs of the FTO gene were examined for their association with body composition and measures of HIV disease progression.

Results: A total of 137 normal weight and 78 overweight/obese participants were studied. Only rs17817449 was associated with BMI in the dominant genetic risk model. FTO SNPs were not associated with laboratory markers of HIV infection at baseline. Fat mass and lean mass both were associated with rs1121980, rs8050136, and rs17817449 with the risk alleles having a higher percentage of fat mass and lower lean body mass compared to the non-risk homozygous allele. Over 18 months, FTO SNPs were not associated with outcomes of HIV disease progression.

Conclusions: FTO SNPs may contribute to the variation in body fat mass and lean mass in adults in Botswana. FTO SNPs were not associated with a protective effect on HIV disease progression. Further studies including GWAS are needed in African populations to clarify whether genetic variation mediates the obesity paradox.
\end{abstract}

Keywords: HIV infection, ART naïve, BMI, disease progression, FTO gene 


\section{Introduction}

Studies have shown that obesity may be protective of further HIV disease progression before initiation of antiretroviral therapy (ART) ${ }^{1-4}$ Obesity was even found to be protective after initiation of ART. ${ }^{5}$ Higher CD4 cell counts and delayed diagnosis of AIDS have been found in those who were overweight or obese. ${ }^{1-3,6,7}$ Those who are obese may have a genetic advantage in maintaining fat stores and utilizing energy to fuel the immune system. Conversely, obesity may also increase one's risk for developing chronic conditions such as cardiovascular diseases, diabetes and cancer. ${ }^{8-10}$ It is also a concern for the HIV patient that is now living longer due to increasing use of antiretrovirals. Information on mechanisms for the potential benefits of obesity in delaying HIV disease progression are lacking.

Obesity has a strong genetic background ${ }^{11}$ which has been estimated to account for $40-70 \%$ of the variation in human adiposity. ${ }^{12}$ The Fat Mass and Obesity Associated (FTO) gene was first identified in $2007^{13}$ and has been associated with obesity and obesity related traits. ${ }^{14,15}$ The hypothalamus is the site where the FTO gene is mainly expressed ${ }^{16}$ and may be involved in energy homeostasis, ${ }^{17}$ and fat cell lipolysis which may regulate body fat. ${ }^{18}$ Specifically, the single nucleotide polymorphism (SNP) of the FTO gene rs9939609 (A allele) is most commonly associated with obesity; ${ }^{13,15,19}$ however this relationship has not been replicated in an African population. Currently, there are no published studies on the FTO gene and its association with obesity in HIV+ patients or in a population in Botswana.

Botswana is experiencing one of the worst epidemics of HIV, with a prevalence rate of $23.4 \%$ among those who are 15 and 49 years of age.$^{20}$ Botswana has the first successfully implemented ART program in Africa and provides universal access to ART 
when CD4 cell counts reach $<350$ cells $/ \mu \mathrm{L} .{ }^{21}$ Botswana, like other African countries, is also experiencing a lifestyle transition that includes increasing rates of obesity. ${ }^{22-24}$

The aim of this preliminary study was to determine the interrelationships among being overweight/obese, markers of genetic propensity for obesity (SNPs in FTO) and HIV disease progression in HIV+ asymptomatic adults in Botswana not on ART over 18 months.

\section{Methods}

\section{Study Design and Participants}

We completed a retrospective study analyzing frozen laboratory specimens from 215 HIV-positive men and women from the placebo group of a multifactorial, randomized, double-blinded, and placebo-controlled clinical trial in Botswana. ${ }^{25}$ This parent study originally included 219 participants in the placebo group, however only 215 participants had sufficient samples for laboratory analysis. The parent study investigated whether supplementation with multivitamins and selenium can improve immune function and prolong time to AIDS in ART naïve HIV infected adults. ${ }^{25}$ The study was performed between December 2004 and July 2009. Confounding effects from the micronutrient supplementation on the outcome measures were avoided by using the participants from the placebo group for the current study. Participants were eligible for the parent study with documentation of HIV seropositive test results, CD4 cell count > 350 cells $/ \mu \mathrm{L}, \mathrm{BMI}>18 \mathrm{~kg} / \mathrm{m}^{2}$ for women and $>18.5 \mathrm{~kg} / \mathrm{m}^{2}$ for men, age $\geq 18$ years, lack of a past history of AIDS-defining conditions, lack of current participation in another blinded clinical trial and still ineligible for receiving ART in Botswana during the study period. Women were excluded if pregnant or had intention to become pregnant. All participants provided informed consent and approval to use their stored blood for future studies. Participants were recruited from the Botswana-Harvard AIDS Initiative 
Partnership (BHP) in Gaborone, Botswana. We obtained approval to use their stored blood for genotyping SNPs from the FTO gene from the Florida International University Institutional Review Board (IRB), the Harvard School of Public Health IRB, and the Botswana Health Research Unit of the National Ministry of Health.

\section{Clinical Data}

At baseline and every three months, physical examination and medical history were performed by a trained nurse or a physician. Anthropometrics were also obtained and body mass index (BMI) was calculated by dividing the participants' weight in $\mathrm{kg}$ by their height in meters ${ }^{2}$.

Waist and hip circumference was measured using a non-stretchable tape measure. Waist circumference was measured at the narrowest part of the waist between the lowest rib and the iliac crest and the hip circumference at the widest portion of the buttocks. Bioelectrical impedance analysis (BIA) was performed using the Biodynamics body composition analyzer (model BIA-310; Biodynamics Corp., Seattle, WA), which provides a print-out of measured impedance and calculated body fat and lean mass. Subjects were measured fasting, without shoes and socks, and electrodes were placed on the participant's right hand and wrist and right foot and ankle. Medical history included intercurrent health events and currently prescribed medications; a review of records was used to verify prescriptions and determine changes in health status. Morbidity information was collected by questionnaires at screening, and at every monthly visit, and confirmed by documentation in the medical chart. Participants were followed medically by the research physicians at the same facilities where the research was conducted to improve compliance with study visits.

Twenty-four hour recalls were conducted at baseline and every 3 months by trained clinical staff. Macronutrient and fiber intakes were calculated using the NutriBase 
Professional, V.9 (Cybersoft, Phoenix, AZ) program modified by the South Africa database, including native foods for which information was available. An average of at least 3 dietary recalls were used to obtain their estimated energy, carbohydrate, protein, fat and fiber intakes. A questionnaire on activity patterns to obtain data on physical activity was completed. Time spent walking was used a measure of physical activity.

\section{Laboratory Data}

At baseline and every six months, blood was also drawn to evaluate HIV viral load, lipid panel, and blood chemistry. Every three months blood was drawn for CD4 and CD8 cell counts. Lymphocyte phenotype was determined with a four-color immunophenotyping panel of monoclonal antibodies. Differential counts were determined using a Coulter MaxM hematology instrument and corroborated with cytocentrifuge smears. HIV-viral load was determined using an in-vitro nucleic acid amplification test (Amplicor reagents and protocol, Roche-Diagnostics, Branchburg, NJ).

\section{Single Nucleotide Polymorphisms for the FTO gene}

The Qiagen QIAamp DNA Blood kit was used to isolate total DNA from plasma samples stored at $-80^{\circ} \mathrm{C}$. The DNA purification procedure was done using a standard microcentrifuge and QIAamp Mini spin columns. A minimum of $200 \mu \mathrm{L}$ of plasma was used to isolate sufficient DNA for analysis.

Polymorphism for the SNPs rs9939609, rs1421085, rs8050136, rs17817449, and rs1121980 of the FTO gene that have previously been associated with BMI were genotyped by TaqMan allelic discrimination assays from Life Technologies Inc. (Carlsbad, CA). Fluorescence was visualized through a real-time PCR system, Bio-Rad CFX96 real-time PCR machine (Hercules, CA). Bio-Rad SsoFast Supermix was used with the TaqMan assay. PCR amplification was completed using $10 \mu \mathrm{L}$ volume. PCR thermal cycling included enzyme activation at $95^{\circ} \mathrm{C}$ for 2 minutes, 49 cycles of 
denaturation at $95^{\circ} \mathrm{C}$ for 5 seconds and annealing and extension at $61^{\circ} \mathrm{C}$ for 5 seconds. A random $10 \%$ of samples were re-genotyped to assess genotyping reproducibility.

\section{Statistical Analysis}

BMI was stratified into two groups: 1. normal weight $\left(B M I=18.0-24.9 \mathrm{~kg} / \mathrm{m}^{2}\right)$ and 2. overweight/obese $\left(\mathrm{BMI}=\geq 25 \mathrm{~kg} / \mathrm{m}^{2}\right)$. Laboratory markers of HIV infection and disease progression included in the analyses were CD4 cell count, CD4\%, CD8 cell count, CD8\%, CD4/CD8 ratio and HIV viral load. Descriptive statistics such as frequencies, percentages, medians and interquartile ranges were used to characterize the two stratified BMI groups at baseline and its relation to the FTO SNPs. KruskalWallis test was used to determine differences in body composition and HIV disease progression markers between the FTO SNP alleles. Chi-square tests were used to determine differences in gender, AIDS defining conditions, BMI groups and FTO SNPS. Logistic regression was used to assess the associations between the BMI groups and the presence of the FTO SNPs. Logistic regression was also used for the dominant genetic risk model in which the subjects homozygous and heterozygous for the variant allele were compared to the wild-type homozygous group for measures of body composition and HIV disease progression. Proportional survival models were used to compare hazard ratios on time to HIV disease progression outcomes between FTO alleles, using the dominant model over 18 months. HIV disease progression outcomes included time to $\geq 25 \%$ decline in CD4 cell count, CD4 cell count $\leq 250$ and/or AIDS defining conditions over 18 months. Models were adjusted for covariates that included age, gender, tribes, baseline CD4, baseline HIV viral load, total dietary kcal intake, and activity. For all analyses, a two sided test was used and $P<0.05$ was considered statistically significant. Statistical analyses were completed using SPSS version 21. 


\section{Results}

\section{Genotype Frequencies and Demographics}

The genotype and allele frequencies of all SNPs are shown in Table 1. Overall, $99 \%$ of the samples were successfully genotyped. Ten percent of the samples were regenotyped with $96 \%$ concordance. All of the SNPs, except for rs 1421085 , were in Hardy-Weinberg equilibrium, $(P>.01)$. Further analysis with SNP rs1421085 was not performed since the minor allele frequency was less than $5 \%$ in this sample and it was not in Hardy-Weinberg equilibrium.

Baseline description of the study participants separated by BMI groups is provided in Table 2. A total of 215 participants, 137 in the normal BMI group and 78 in the overweight/obese BMI were included in the analysis, as four participants were excluded for having missing data. The overweight/obese group was older (median (IQR)) $(35.00(30.00-43.00))$ than the normal BMI group (31.00 (28.00-38.00), $P<.004)$ and had a greater proportion of women $(87.20 \%$ vs. $69.30, P<.001)$. There were no statistically significant differences between these groups in laboratory markers of HIV infection at baseline.

\section{Association of FTO SNPs, Body Composition and Laboratory Markers of HIV Infection}

SNPs rs1121980, rs8050136, and rs9939609 genotypes were not associated with measures of body composition and laboratory markers of HIV infection at baseline (Tables 3-6). As shown in Table 6, the SNP rs17817449 had a marginal additive model association with BMI $(P=.088)$, fat mass $(P=.088)$, and lean mass $(P=.085)$ reflecting a possible gene-dosage effect. Subjects with the GG genotype had higher BMI and fat mass and lower lean mass compared to the other genotypes, albeit not statistically significant. 
Regression analysis was completed using the dominant model for all SNPs for examination of their relationships with measures of body composition and laboratory markers of HIV infection (Tables 7-10). A significant relationship with rs8050136 was seen with fat mass $(\mathrm{OR}=1.078 ; 95 \% \mathrm{Cl}=1.021,1.140 ; P=.007)$ and lean mass $(\mathrm{OR}=.928 ; 95 \% \mathrm{Cl}=.878, .981 ; P=.008) . \mathrm{SNP}$ rs17817449 was the only SNP associated with $\mathrm{BMI}(\mathrm{OR}=1.082 ; 95 \% \mathrm{Cl}=1.001,1.169 ; P=.047)$. SNP rs17817449 was also associated with fat mass $(\mathrm{OR}=1.086 ; 95 \% \mathrm{C}=, 1.031,1.145 ; P=.002)$ and lean mass $(\mathrm{OR}=.921 ; 95 \% \mathrm{Cl}=.874, .971 ; P=.002)$. Similarly, $\mathrm{rs} 1121980$ had significant relationships with fat mass $(\mathrm{OR}=1.065 ; 95 \% \mathrm{Cl}=1.009,1.125, P=.021)$ and lean mass $(\mathrm{OR}=.939 ; 95 \% \mathrm{Cl}=.889, .991 ; P=.022)$.

Separate analyses were conducted by gender using logistic regression models to examine relationships between FTO SNPs, body composition and laboratory markers of HIV infection. In females, rs8050136 in the dominant model showed a statistically significant association with fat mass $(\mathrm{OR}=1.102 ; 95 \% \mathrm{Cl}=1.029,1.179 ; P=.005)$ and lean mass $(\mathrm{OR}=.909 ; 95 \% \mathrm{Cl}=.849, .973 ; P=.006)$. The SNP $\mathrm{rs} 17817449$ was also significantly associated with fat mass $(\mathrm{OR}=1.099 ; 95 \% \mathrm{Cl}=1.031,1.171 ; P=.008)$ and lean mass $(\mathrm{OR}=.911 ; 95 \% \mathrm{Cl}=.855, .971 ; P=.004)$. No other SNPs had significant results for gender-specific associations.

Although none of the SNPs had significant findings using the dominant model with laboratory markers of HIV infection, rs8050136 did have a trend relationship with HIV viral load $(\mathrm{OR}=.705 ; 95 \% \mathrm{Cl}=.481,1.035 ; P=.074)$, showing a protective effect. As shown in Tables 12-15, the FTO SNPs were not associated with HIV disease progression outcomes of $25 \%$ decline in CD4, CD4 $\leq 250$ cells/ $\mu \mathrm{L}$ and/or AIDS defining conditions over 18 months using Cox proportional hazard models. 


\section{Discussion}

This study provides preliminary data on the influence of FTO variants on the risk of being overweight/obese in HIV+ adults in Botswana. No significant associations were found with the SNP variants and waist or waist-to-hip ratio. The variant rs17817449 showed a trend towards higher BMI with the risk allele (GG) compared with the non-risk allele (TT). This variant also had a significant association with BMI, showing a greater odds of having higher BMI when the risk allele is present, after controlling for age, gender, tribe, total kcal intake and activity. In a study conducted in South African adolescents, rs17817449 was also associated with BMI after adjusting for age, gender and pubertal stage. ${ }^{26}$ They showed a $1.9 \%$ effect size increase in BMI for each risk allele. The relationship between measures of obesity and FTO variants has been contradictory among indigenous African populations. In West Africans, ${ }^{27}$ several SNPs were associated with BMI, waist circumference and percent fat mass; however, no association was found with rs9939609, which is the most replicated SNP in the literature. A replication study completed with lean Gambian adults did not show any associations between 16 FTO SNPs and measures of body mass, but phenotypic comparisons of obesity could not be evaluated since participants that were obese were not part of the study. $^{28}$

Fat mass and lean mass were associated with rs1121980, rs8050136, and rs17817449 with the risk alleles having a higher percentage of fat mass and lower lean body mass compared to homozygosity for the non-risk allele. Adeyemo et al. ${ }^{27}$ also investigated percent body fat in West Africans and showed significant relationships with FTO SNPs; however, the investigators did not report significant findings with any of the SNPs included in our study. Although the exact mechanism for the effect of FTO on weight is unknown, it is hypothesized that it may affect food intake and energy 
expenditure. ${ }^{29}$ FTO is highly expressed in the hypothalamus region of the brain, where food intake is controlled. ${ }^{16}$ In several studies, rs9939609 was shown to be associated with higher food intake in children and adults. ${ }^{30-33}$ Greater levels of FTO mRNA have also been found in the adipose tissue of obese persons. ${ }^{34-35}$ Although, FTO may regulate adiposity, factors that influence mobilization of adipose tissue such as leptin, have not been consistently demonstrated.

This is the first study that examined FTO SNPs in HIV+ adults in Africa.

Botswana is known to be a heterogeneous population with many ethnic groups. ${ }^{36}$ All of the SNPs were in Hardy Weinberg equilibrium, except for rs1421085, which also had a minor allele frequency of less than $5 \%$ in this sample. The SNP rs 1421085 was excluded from the analyses; however, similar genotype frequencies for this SNP were also seen in the reference population of the Yoruba tribe from Africa. ${ }^{37}$ The heterogeneity present in this population may also be a limitation for this study.

Studies have shown that obesity may be protective of further HIV disease progression. ${ }^{4,38}$ We showed in this same cohort that higher fat mass was associated with a decreased risk of AIDS defining conditions and CD4 cell count $<250$ cells $/ \mu \mathrm{L}$ (unpublished data). This protection provided by fat may be explained partially through its association with leptin, an adipokine secreted by adipose tissue. Higher fat mass is associated with higher levels of leptin, which has been shown to be associated with proliferation and reduced apoptosis of immune cells such as CD4+ T-cells. ${ }^{41,42}$ In the current analysis, we did not find any significant effects of FTO variants on laboratory markers of HIV infection and disease progression over time. However, our findings suggest that FTO SNPs may indirectly influence HIV disease progression through their effect on fat mass before ART initiation. 
Based on our analyses, further studies should include a larger sample size to be able to examine the associations with the SNPs of the FTO gene, BMI and HIV disease progression with greater statistical power. A larger sample size would have allowed for the examination of the relationship of the FTO variants and body mass in further stratified subgroups of overweight and obese separately. Including other candidate SNPs of the FTO gene would also provide a better understanding of the role of the variants in the FTO gene on BMI or obesity in this population. Controlling for other variable that might affect BMI such as medications, time of HIV diagnosis, and comorbidities may also provide a better grasp on the effect of the gene on the phenotypic outcomes.

The FTO still remains the gene most consistently associated with obesity in various populations, ${ }^{43}$ but its associations have not been replicated in many African populations. GWAS studies in African populations are lacking, and identifying SNPs that are relevant to this population is of importance since the SNPs showing associations in European and Asian populations may be different from SNPs that will show associations in African populations. In this study, the SNPs chosen were based on those most associated with BMI in the literature; however, only rs17817449 had a significant relationships with BMI. Significant associations were seen with percent body fat mass and lean mass which have been essential factors in HIV disease progression. ${ }^{44,45}$ A recent publication by Monda et al. ${ }^{46}$ identified new loci within the FTO gene that was associated with BMI in individuals of African ancestry; however, the authors concluded that SNPs were not likely to contribute to population differences in obesity, highlighting the importance of further studies.

This preliminary study did have limitations which may affect the interpretation of our findings. Our study only included 215 participants and may not have had sufficient 
statistical power, as genetic association studies usually require a large number of participants. This study was retrospective in design. No underweight participants were included in the parent study and only a few cases of morbid obesity were present, which did not allow for the full spectrum of BMI to be examined and lowered the statistical power. The findings of this study are pertinent to this specific population and not generalizable to all African populations.

In summary, our data indicate that FTO SNPs may contribute to the variation in body fat mass and lean mass in adults in Botswana. FTO SNPs were not directly associated with a protective effect on HIV disease progression. Additional loci within the FTO gene should be examined in African populations to enhance our comprehension of their influence on obesity and its benefits and risk factors.

\section{Acknowledgements}

The parent study was funded by the National Institute on Drug Abuse (R01-DA-016551). The genotyping was supported by Minority Biomedical Research Support (MBRS) RISE Biomedical Research Initiative (BRI) Research Award. We thank all of the participants in the study without whom advancement in the nutritional management of the HIV disease would not have been possible. 
Table 1: FTO SNP Allele and Genotype Frequencies in HIV+ Adults in Botswana

\begin{tabular}{|l|c|c|c|c|c|c|c|}
\hline & $\begin{array}{c}\text { Major } \\
\text { allele }\end{array}$ & $\begin{array}{c}\text { Minor } \\
\text { allele }\end{array}$ & \multicolumn{3}{|c|}{$\begin{array}{c}\text { Genotype } \\
\text { frequencies }\end{array}$} & \multicolumn{2}{c|}{ Allele frequencies } \\
\hline dbSNP ID & (A) & (B) & (AA) & $(A B)$ & $(B B)$ & Major & Minor \\
\hline rs1121980 & T & C & 0.241 & 0.474 & 0.274 & 0.516 & 0.484 \\
\hline rs1421085 & T & C & 0.917 & 0.056 & 0.019 & 0.953 & 0.047 \\
\hline rs8050136 & A & C & 0.239 & 0.452 & 0.300 & 0.530 & 0.470 \\
\hline rs9939609 & A & T & 0.247 & 0.493 & 0.252 & 0.502 & 0.498 \\
\hline rs17817449 & T & G & 0.366 & 0.412 & 0.213 & 0.577 & 0.423 \\
\hline
\end{tabular}


Table 2: Demographic Characteristics by BMI Group ( $\mathrm{N}=215)$

\begin{tabular}{|c|c|c|c|}
\hline Variable & $\begin{array}{l}\text { Normal BMI } \\
(\mathrm{N}=137)\end{array}$ & $\begin{array}{c}\text { Overweight/ } \\
\text { Obese BMI }(\mathrm{N}=78)\end{array}$ & $\begin{array}{c}P_{-} \\
\text {value }\end{array}$ \\
\hline Age (years) & $31.00(28.00-38.00)$ & $35.00(30.00-43.00)$ & $.004^{b}$ \\
\hline \multicolumn{4}{|l|}{ Gender $^{a}$} \\
\hline Male & $42(30.70)$ & $10(12.80)$ & $.003^{b}$ \\
\hline Female & 95 (69.30) & $68(87.20)$ & \\
\hline Waist (inches) & $30.71(29.13-32.28)$ & 37.64 (34.84-39.27) & $<.001^{b}$ \\
\hline Waist-to-hip ratio & $.80(.78-.85)$ & $.85(.79-.88)$ & $<.013^{b}$ \\
\hline Lean mass (\%) & $74.90(70.40-80.00)$ & $65.10(62.10-67.50)$ & $<.001^{\mathrm{b}}$ \\
\hline Fat mass $(\%)$ & $25.10(20.00-25.10)$ & $34.90(32.50-37.90)$ & $<.001^{b}$ \\
\hline CD4 cell count (cells/ $\mu \mathrm{L})$ & $\begin{array}{c}415.87(324.02- \\
546.99)\end{array}$ & $\begin{array}{c}401.10(331.24- \\
545.24)\end{array}$ & .935 \\
\hline CD4 \% & $27.02(20.19-31.19)$ & 23.66 (18.88-30.07) & .151 \\
\hline CD8 cell count (cells/ $\mu \mathrm{L})$ & $\begin{array}{c}797.05(588.47- \\
1225.48)\end{array}$ & $\begin{array}{c}891.36(669.20- \\
1177.81)\end{array}$ & \\
\hline CD8 \% & $52.24(44.18-58.29)$ & $49.92(43.40-59.28)$ & .228 \\
\hline CD4/CD8 Ratio & $.54(.37-.67)$ & $.49(.32-.71)$ & .624 \\
\hline $\begin{array}{l}\text { HIV viral load }\left(\log _{10}\right. \\
\text { copies/mL) }\end{array}$ & $4.33(3.60-4.82)$ & $4.22(3.30-4.82)$ & .586 \\
\hline
\end{tabular}


Table 3: FTO rs1121980: Association with Body Composition and Measures of HIV Disease Progression

\begin{tabular}{|c|c|c|c|c|}
\hline Variable & TT & $\mathrm{TC}$ & $\mathrm{CC}$ & $\begin{array}{c}\mathrm{P}- \\
\text { value }\end{array}$ \\
\hline Age (years) & $33(29-39)$ & $33(28-39)$ & $32(28-42)$ & .829 \\
\hline BMI $\left(\mathrm{kg} / \mathrm{m}^{2}\right)$ & $21.60(28.83-25.95)$ & $23.60(20.48-27.70)$ & $22.60(20.70-26.60)$ & .614 \\
\hline Waist (inches) & $31.10(29.53-34.65)$ & $33.27(29.92-37.30)$ & $32.28(29.92-35.04)$ & .425 \\
\hline Waist-to-hip ratio & $.84(.78-.88)$ & $.80(.79-.85)$ & $.82(.78-.88)$ & .146 \\
\hline Lean mass (\%) & 72.25 (65.65-77.28) & $70.25(64.28-75.90)$ & $71.10(65.48-76.03)$ & .273 \\
\hline Fat mass $(\%)$ & $27.75(22.73-34.35)$ & $29.45(24.10-35.73)$ & $28.90(23.98-33.53)$ & .278 \\
\hline CD4 cell count (cells $/ \mu \mathrm{L})$ & 409.03 (329.59-566.49) & $413.58(324.17-544.17)$ & $417.66(325.80-560.00)$ & .901 \\
\hline CD4\% & $25.19(19.32-31.58)$ & $25.68(16.69-30.56)$ & $26.45(19.58-30.61)$ & .967 \\
\hline CD8 cell count (cells/ $\mu \mathrm{L})$ & $905.58(650.25-1297.91)$ & $839.66(619.65-1159.03)$ & 789.35 (604.56-1110.60) & .627 \\
\hline CD8\% & $52.45(44.11-60.19)$ & $51.14(42.80-58.55)$ & $50.88(43.50-58.54)$ & .769 \\
\hline CD4/CD8 ratio & $.51(.33-.65)$ & $.53(.34-.72)$ & $.51(.36-.64)$ & .886 \\
\hline $\begin{array}{l}\text { HIV viral load }\left(\log _{10}\right. \\
\text { copies } / \mathrm{mL})\end{array}$ & $4.11(3.28-4.92)$ & $4.34(3.42-4.81)$ & $4.37(3.71-4.82)$ & .507 \\
\hline
\end{tabular}


Table 4: FTO rs8050136: Association with Body Composition and Measures of HIV Disease Progression

\begin{tabular}{|c|c|c|c|c|}
\hline Variable & AA & $\mathrm{AC}$ & $\mathrm{CC}$ & $\begin{array}{c}\mathrm{P}- \\
\text { value }\end{array}$ \\
\hline Age (years) & $34(29-39)$ & $32(28-39)$ & $32(28-43)$ & .343 \\
\hline BMI $\left(\mathrm{kg} / \mathrm{m}^{2}\right)$ & $23.10(21.30-27.10)$ & $23.65(20.35-27.33)$ & $22.4(20.45-25.95)$ & .641 \\
\hline Waist (inches) & $32.09(29.92-36.81)$ & $33.46(30.12-36.32)$ & $32.28(29.52-34.45)$ & .272 \\
\hline Waist-to-hip ratio & $.84(.79-.84)$ & $.81(.79-.85)$ & $.82(.78-.88)$ & .396 \\
\hline Lean mass (\%) & $71.40(66.88-75.55)$ & 70.05 (64.95-75.88) & $71.70(67.50-79.85)$ & .162 \\
\hline Fat mass $(\%)$ & $28.60(24.45-33.13)$ & $29.95(24.13-35.05)$ & $28.30(20.15-32.50)$ & .159 \\
\hline CD4 cell count (cells $/ \mu \mathrm{L})$ & $407.53(325.55-580.64)$ & $403.33(318.04-532.34)$ & $415.87(343.72-545.17)$ & .533 \\
\hline CD4\% & $26.35(19.60-31.95)$ & $27.36(19.58-30.56)$ & $24.80(19.74-30.24)$ & .794 \\
\hline CD8 cell count (cells/ $\mu \mathrm{L})$ & $845.60(586.65-1249.86)$ & 773.38 (597.30-1120.43) & $960.91(667.27-1249.21)$ & .280 \\
\hline CD8\% & $52.28(42.66-57.92)$ & $48.59(42.96-58.55)$ & $53.54(46.33-59.40)$ & .217 \\
\hline CD4/CD8 ratio & $.54(.36-.71)$ & $.56(.34-.69)$ & $.44(.35-.63)$ & .474 \\
\hline $\begin{array}{l}\text { HIV viral load }\left(\log _{10}\right. \\
\text { copies } / \mathrm{mL})\end{array}$ & $4.13(3.63-4.71)$ & $4.34(3.23-4.90)$ & $4.35(3.67-4.78)$ & .577 \\
\hline
\end{tabular}


Table 5: FTO rs9939609: Association with BMI, Body Composition and Measures of HIV Disease Progression

\begin{tabular}{|c|c|c|c|c|}
\hline Variable & AA & AT & TT & $\begin{array}{c}P_{-} \\
\text {value }\end{array}$ \\
\hline Age (years) & $31(28-43)$ & $33(28-39)$ & $34(29-40)$ & .656 \\
\hline $\mathrm{BMI}\left(\mathrm{kg} / \mathrm{m}^{2}\right)$ & $22.25(20.05-25.08)$ & $24.20(20.83-27.80)$ & $22.80(21.25-26.60)$ & .105 \\
\hline Waist (inches) & 32.28 (29.53-34.25) & 33.27 (29.92-37.30) & 31.99 (29.92-35.91) & .266 \\
\hline Waist-to-hip ratio & $.82(.79-.88)$ & $.81(.78-.87)$ & $.83(.78-.88)$ & .478 \\
\hline Lean mass $(\%)$ & $71.70(67.50-79.70)$ & $70.55(65.65-75.90)$ & $70.40(65.25-76.00)$ & .507 \\
\hline Fat mass (\%) & $28.30(20.30-32.50)$ & $29.45(24.10-34.35)$ & $29.60(24.00-34.75)$ & .500 \\
\hline CD4 cell count (cells $/ \mu \mathrm{L})$ & 414.54 (342.38-537.99) & $421.13(319.79-550.40)$ & 397.88 (324.59-537.28) & .908 \\
\hline CD4\% & $25.21(19.20-28.68)$ & $27.19(19.52-31.78)$ & $26.42(19.65-31.50)$ & .516 \\
\hline CD8 cell count (cells/ $\mu \mathrm{L})$ & 933.94 (613.96-1296.52) & 838.63 (629.54-1171.28) & 813.47 (586.34-1117.45) & .532 \\
\hline CD8\% & $54.01(47.92-60.58)$ & $48.76(43.91-59.09)$ & $52.57(42.49-56.23)$ & .187 \\
\hline CD4/CD8 ratio & $.48(.34-.60)$ & $.56(.33-.71)$ & $.50(.36-.71)$ & .349 \\
\hline $\begin{array}{l}\text { HIV viral load }\left(\log _{10}\right. \\
\text { copies } / \mathrm{mL})\end{array}$ & $4.39(3.68-4.80)$ & $4.34(3.41-4.92)$ & $4.19(3.35-4.74)$ & .605 \\
\hline
\end{tabular}


Table 6: FTO rs17817449: Association with Body Composition and Measures of HIV Disease Progression

\begin{tabular}{|c|c|c|c|c|}
\hline Variable & TT & GT & GG & $\begin{array}{c}\mathrm{P}- \\
\text { value }\end{array}$ \\
\hline Age (years) & $31(28-40)$ & $33(28-39)$ & $35(29-39)$ & .343 \\
\hline BMI $\left(\mathrm{kg} / \mathrm{m}^{2}\right)$ & $22.20(20.43-25.83)$ & $23.60(20.25-27.38)$ & $23.95(21.58-27.85)$ & .088 \\
\hline Waist (inches) & 31.69 (29.53-34.65) & $33.27(29.92-36.37)$ & $32.29(30.09-34.93)$ & .222 \\
\hline Waist-to-hip ratio & $.82(.78-.88)$ & $.80(.79-.87)$ & $.82(.77-.88)$ & .808 \\
\hline Lean mass (\%) & $73.60(66.38-80.00)$ & $70.30(65.40-76.40)$ & $68.75(65.08-73.70)$ & .085 \\
\hline Fat mass $(\%)$ & $26.40(20.00-33.63)$ & $29.70(23.60-34.60)$ & $31.25(26.30-34.93)$ & .088 \\
\hline CD4 cell count (cells $/ \mu \mathrm{L})$ & $407.04(323.34-532.84)$ & $442.65(334.44-558.80)$ & $397.94(330.16-513.81)$ & .517 \\
\hline CD4\% & $25.29(18.92-30.09)$ & $26.59(19.73-30.88)$ & $25.93(19.60-31.88)$ & .640 \\
\hline CD8 cell count (cells/ $\mu \mathrm{L})$ & 866.85 (616.07-1115.62) & 839.66 (623.67-1263.82) & $783.42(584.47-1150.51)$ & .628 \\
\hline CD8\% & $52.33(46.42-58.45)$ & $51.28(42.57-59.50)$ & $51.18(43.37-56.76)$ & .447 \\
\hline CD4/CD8 ratio & $.49(.34-.62)$ & $.55(.34-.68)$ & $.55(.36-.72)$ & .432 \\
\hline $\begin{array}{l}\text { HIV viral load }\left(\log _{10}\right. \\
\text { copies } / \mathrm{mL})\end{array}$ & $4.38(3.66-4.81)$ & $4.35(3.41-4.950$ & $4.10(3.46-4.65)$ & .360 \\
\hline
\end{tabular}


Table 7: Association of FTO rs1121980 with Body Composition and HIV disease Progression in a Dominant Model ${ }^{*}$

\begin{tabular}{|c|c|c|c|}
\hline Variable & $\mathrm{OR}^{\mathrm{a}}$ & $95 \% \mathrm{Cl}^{\mathrm{b}}$ & $P$-value \\
\hline BMl groups ${ }^{* *}$ & 1.549 & $.754,3.182$ & .234 \\
\hline BMI $\left(\mathrm{kg} / \mathrm{m}^{2}\right)$ & 1.057 & $.974,1.147$ & .183 \\
\hline Waist (inches) & 1.049 & $.951,1.157$ & .338 \\
\hline Waist-to-hip ratio & .144 & $.001,134.902$ & .574 \\
\hline Lean mass (\%) & .939 & $.889, .991$ & $.022^{\mathrm{C}}$ \\
\hline Fat mass $(\%)$ & 1.065 & $1.009,1.125$ & $.021^{\mathrm{c}}$ \\
\hline CD4 cell count (cells/ $\mu \mathrm{L})$ & 1.001 & $.999,1.003$ & .492 \\
\hline CD4\% & 1.006 & $.963,1.050$ & .804 \\
\hline CD8 cell count (cells/ $\mu \mathrm{L})$ & 1.001 & $.999,1.001$ & .397 \\
\hline CD8\% & .993 & $.963,1.023$ & .625 \\
\hline CD4/CD8 ratio & 1.443 & $.463,4.495$ & .527 \\
\hline HIV viral load ( $\log _{10}$ copies $/ \mathrm{mL}$ ) & .736 & $.498,1.087$ & .124 \\
\hline
\end{tabular}

${ }^{* *}$ Dominant model: homozygous and heterozygous for the variant were compared to the wild-type homozygous. Models adjusted for age, gender, tribes, total kcal dietary intake and activity

${ }^{* *} \mathrm{BMl}$ groups: $0=\mathrm{BMI} 18.0-24.9 \mathrm{~kg} / \mathrm{m}^{2}$ and $1=\mathrm{BMI} \geq 25 \mathrm{~kg} / \mathrm{m}^{2}$

${ }^{\mathrm{a} O R}=$ Odds Ratio

${ }^{\mathrm{b}} \mathrm{Cl}=$ Confidence Intervals

'Statistically significant, $P<.05$ 
Table 8: Association of FTO rs8050136 with Body Composition and HIV disease Progression in a Dominant Model ${ }^{*}$

\begin{tabular}{|c|c|c|c|}
\hline Variable & $\mathrm{OR}^{\mathrm{a}}$ & $95 \% \mathrm{Cl}^{\mathrm{b}}$ & $P$-value \\
\hline BMl groups ${ }^{* *}$ & 1.584 & $.776,3.231$ & .207 \\
\hline BMI $\left(\mathrm{kg} / \mathrm{m}^{2}\right)^{\mathrm{a}}$ & 1.071 & $.988,1.162$ & .097 \\
\hline Waist (inches) ${ }^{a}$ & 1.084 & $.980,1.199$ & .117 \\
\hline Waist-to-hip ratio & 1.641 & $.002,1142.635$ & .882 \\
\hline Lean mass (\%) & .928 & $.878, .981$ & $.008^{\mathrm{c}}$ \\
\hline Fat mass $(\%)$ & 1.078 & $1.021,1.140$ & $.007^{\mathrm{c}}$ \\
\hline CD4 cell count (cells/ $\mu \mathrm{L})$ & 1.001 & $.998,1.002$ & .825 \\
\hline CD4\% & 1.013 & $.972,1.057$ & .534 \\
\hline CD8 cell count (cells/ $\mu \mathrm{L})$ & 1.001 & $.999,1.001$ & .390 \\
\hline CD8\% & .981 & $.952,1.010$ & 190 \\
\hline CD4/CD8 ratio & 1.347 & $.473,3.835$ & .577 \\
\hline HIV viral load ( $\log _{10}$ copies $/ \mathrm{mL}$ ) & .705 & $.481,1.035$ & .074 \\
\hline
\end{tabular}

${ }^{* *}$ Dominant model: homozygous and heterozygous for the variant were compared to the wild-type homozygous. Models adjusted for age, gender, tribes, total dietary kcal, and activity

${ }^{* *}$ BMl groups: $0=\mathrm{BMI} 18.0-24.9 \mathrm{~kg} / \mathrm{m}^{2}$ and $1=\mathrm{BMI} \geq 25 \mathrm{~kg} / \mathrm{m}^{2}$

${ }^{\mathrm{a} O R} \mathrm{O}=$ Odds Ratio

${ }^{\mathrm{b}} \mathrm{Cl}=$ Confidence Intervals

'Statistically significant, $P<.05$ 
Table 9: Association of FTO rs9939609 with Body Composition and HIV disease Progression in a Dominant Model ${ }^{*}$

\begin{tabular}{|c|c|c|c|}
\hline Variable & $\mathrm{OR}^{\mathrm{a}}$ & $95 \% \mathrm{Cl}^{\mathrm{b}}$ & $P$-value \\
\hline BMl groups ${ }^{\star *}$ & .956 & $.455,2.007$ & .904 \\
\hline BMI $\left(\mathrm{kg} / \mathrm{m}^{2}\right)$ & .991 & $.918,1.070$ & .818 \\
\hline Waist (inches) & 1.501 & $.056,39.884$ & .808 \\
\hline Waist-to-hip ratio & 1.018 & $.926,1.118$ & .716 \\
\hline Lean mass (\%) & 1.029 & $.975,1.087$ & .294 \\
\hline Fat mass $(\%)$ & .971 & $.920,1.025$ & .290 \\
\hline CD4 cell count (cells/ $\mu \mathrm{L})$ & 1.001 & $.998,1.002$ & .868 \\
\hline CD4\% & .982 & $.940,1.026$ & .424 \\
\hline CD8 cell count (cells/ $\mu \mathrm{L})$ & 1.001 & $1.000,1.001$ & .159 \\
\hline CD8\% & 1.013 & $.983,1.043$ & .405 \\
\hline CD4/CD8 ratio & .861 & $.310,2.394$ & .774 \\
\hline HIV viral load ( $\log _{10}$ copies $/ \mathrm{mL}$ ) & 1.204 & $.811,1.788$ & .357 \\
\hline
\end{tabular}

${ }^{* *}$ Dominant model: homozygous and heterozygous for the variant were compared to the wild-type homozygous. Models adjusted for age, gender, tribes, total dietary kcal and activity

${ }^{* *}$ BMl groups: $0=\mathrm{BMI} 18.0-24.9 \mathrm{~kg} / \mathrm{m}^{2}$ and $1=\mathrm{BMI} \geq 25 \mathrm{~kg} / \mathrm{m}^{2}$

${ }^{\mathrm{a} O \mathrm{O}}=$ Odds Ratio

${ }^{\mathrm{b}} \mathrm{Cl}=$ Confidence Intervals 
Table 10: Association of FTO rs17817449 with Body Composition and HIV disease Progression in a Dominant Model ${ }^{*}$

\begin{tabular}{|c|c|c|c|}
\hline Variable & $\mathrm{OR}^{\mathrm{a}}$ & $95 \% \mathrm{Cl}^{\mathrm{b}}$ & $P$-value \\
\hline BMl groups ${ }^{\star *}$ & 1.732 & $.885,3.388$ & .109 \\
\hline BMI $\left(\mathrm{kg} / \mathrm{m}^{2}\right)$ & 1.082 & $1.001,1.169$ & $.047^{\mathrm{c}}$ \\
\hline Waist (inches) & 1.093 & $.954,1.203$ & .067 \\
\hline Waist-to-hip ratio & .132 & $.000,59.237$ & .516 \\
\hline Lean mass (\%) & .921 & $.874, .971$ & $.002^{\mathrm{C}}$ \\
\hline Fat mass $(\%)$ & 1.086 & $1.031,1.145$ & $.002^{\mathrm{c}}$ \\
\hline CD4 cell count (cells/ $\mu \mathrm{L})$ & 1.002 & $1.001,1.004$ & .136 \\
\hline CD4\% & 1.013 & $.979,1.060$ & .360 \\
\hline CD8 cell count (cells $/ \mu \mathrm{L})$ & 1.001 & $.999,1.001$ & .862 \\
\hline CD8\% & .986 & $.959,1.013$ & .290 \\
\hline CD4/CD8 ratio & 1.500 & $.552,4.076$ & .426 \\
\hline HIV viral load ( $\log _{10}$ copies $/ \mathrm{mL}$ ) & .781 & $.550,1.111$ & .169 \\
\hline
\end{tabular}

*Dominant model: homozygous and heterozygous for the variant were compared to the wild-type homozygous. Models adjusted for age, gender, tribes, total dietary kcal and activity

${ }^{* *}$ BMl groups: $0=\mathrm{BMI} 18.0-24.9 \mathrm{~kg} / \mathrm{m}^{2}$ and $1=\mathrm{BMI} \geq 25 \mathrm{~kg} / \mathrm{m}^{2}$

${ }^{\mathrm{a} O R} \mathrm{O}=$ Odds Ratio

${ }^{\mathrm{b}} \mathrm{Cl}=$ Confidence Intervals

'Statistically significant, $P<.05$ 
Table 11: Adjusted Hazard Ratios on the Effect of rs1121980 Using the Dominant Model on HIV Disease Progression Outcomes in HIV+ Adults in Botswana During a Follow-up Period of 18 Months*

\begin{tabular}{lccc}
\hline Outcome & $\mathrm{HR}^{\mathrm{b}}$ & $95 \% \mathrm{Cl}^{\mathrm{c}}$ & $P$-value \\
\hline$\geq 25 \%$ decline in CD4 cell count & 1.326 & $.837,2.100$ & .230 \\
CD4 cell count $\leq 250 / \mu \mathrm{L}$ & 1.875 & $.544,6.469$ & .320 \\
AIDS Defining Conditions** & 1.536 & $.165,14.264$ & .706 \\
CD4 cell count $\leq 250 / \mu \mathrm{L} \&$ AIDS & 1.203 & $.416,3.475$ & .733 \\
Defining Conditions & & & \\
\hline
\end{tabular}

${ }^{*}$ Cox proportional hazards model were used to examine the effect of rs1121980 on individual HIV disease progression outcomes. Dominant model used for rs1121980:

homozygous and heterozygous for the variant were compared to the wild-type homozygous. All individual HIV disease progression outcomes were analyzed as separate models and adjusted for age, gender, tribe, baseline CD4 count, baseline viral load, total dietary kcal, and activity.

${ }^{* *}$ Models adjusted for age, gender and baseline CD4 cell count, baseline viral load, total dietary kcal and activity

a Statistically significant, $P<.05$

${ }^{b} \mathrm{HR}=$ Hazard Ratio

${ }^{\mathrm{C}} \mathrm{Cl}=$ Confidence Interval 
Table 12: Adjusted Hazard Ratios on the Effect of rs8050136 Using the Dominant Model on HIV Disease Progression Outcomes in HIV+ Adults in Botswana During a Follow-up Period of 18 Months*

\begin{tabular}{lccc}
\hline Outcome & $\mathrm{HR}^{\mathrm{b}}$ & $95 \% \mathrm{Cl}^{\mathrm{c}}$ & $P$-value \\
\hline$\geq 25 \%$ decline in CD4 cell count & .946 & $.610,1.468$ & .805 \\
CD4 cell count $\leq 250 / \mu \mathrm{L}$ & 1.269 & $.394,4.082$ & .690 \\
AIDS Defining Conditions** & .279 & $.042,1.854$ & .187 \\
CD4 cell count $\leq 250 / \mu \mathrm{L} \&$ AIDS & .842 & $.303,2.339$ & .742 \\
Defining Conditions & & & \\
\hline
\end{tabular}

${ }^{*}$ Cox proportional hazards model were used to examine the effect of rs8050136 on individual HIV disease progression outcomes. Dominant model used for rs8050136:

homozygous and heterozygous for the variant were compared to the wild-type homozygous. All individual HIV disease progression outcomes were analyzed as separate models and adjusted for age, gender, tribe, baseline CD4 count, baseline viral load, total dietary kcal, and activity.

${ }^{* *}$ Models adjusted for age, gender and baseline CD4 cell count, baseline viral load, total dietary kcal, and activity

a Statistically significant, $P<.05$

${ }^{b} \mathrm{HR}=$ Hazard Ratio

${ }^{\mathrm{C}} \mathrm{Cl}=$ Confidence Interval 
Table 13: Adjusted Hazard Ratios on the Effect of rs9939609 Using the Dominant Model on HIV Disease Progression Outcomes in HIV+ Adults in Botswana During a Follow-up Period of 18 Months*

\begin{tabular}{lccc}
\hline Outcome & $\mathrm{HR}^{\mathrm{b}}$ & $95 \% \mathrm{Cl}^{\mathrm{c}}$ & $P$-value \\
\hline$\geq 25 \%$ decline in CD4 cell count & 1.039 & $.631,1.709$ & .881 \\
CD4 cell count $\leq 250 / \mu \mathrm{L}$ & 1.141 & $.350,3.712$ & .827 \\
AIDS Defining Conditions** & - & - & - \\
CD4 cell count $\leq 250 / \mu \mathrm{L} \&$ AIDS & 1.399 & $.443,4.412$ & .567 \\
Defining Conditions & & & \\
\hline
\end{tabular}

${ }^{*}$ Cox proportional hazards model were used to examine the effect of rs9939609 on individual HIV disease progression outcomes. Dominant model used for rs9939609:

homozygous and heterozygous for the variant were compared to the wild-type homozygous. All individual HIV disease progression outcomes were analyzed as separate models and adjusted for age, gender, tribe, baseline CD4 count, baseline viral load, total dietary kcal, and activity.

${ }^{* *}$ Model did not converge all AIDS defining conditions occurring in group with risk alleles astatistically significant, $P<.05$

${ }^{b} \mathrm{HR}=$ Hazard Ratio

${ }^{\mathrm{C}} \mathrm{Cl}=$ Confidence Interval 
Table 14: Adjusted Hazard Ratios on the Effect of rs17817449 Using the Dominant Model on HIV Disease Progression Outcomes in HIV+ Adults in Botswana During a Follow-up Period of 18 Months*

\begin{tabular}{lccc}
\hline Outcome & $\mathrm{HR}^{\mathrm{b}}$ & $95 \% \mathrm{Cl}^{\mathrm{c}}$ & $P$-value \\
\hline$\geq 25 \%$ decline in CD4 cell count & .977 & $.641,1.489$ & .913 \\
CD4 cell count $\leq 250 / \mu \mathrm{L}$ & 1.517 & $.520,4.421$ & .445 \\
AIDS Defining Conditions** & .387 & $.060,2.490$ & .317 \\
CD4 cell count $\leq 250 / \mu \mathrm{L} \&$ AIDS & 1.205 & $.468,3.101$ & .700 \\
Defining Conditions & & & \\
\hline${ }^{*}$ Cox proportional hazards model were used to examine the effect of rs17817449 on \\
individual HIV disease progression outcomes. Dominant model used for rs17817449: \\
homozygous and heterozygous for the variant were compared to the wild-type \\
homozygous. All individual HIV disease progression outcomes were analyzed as \\
separate models and adjusted for age, gender, tribe, baseline CD4 count, baseline viral \\
load, total dietary kcal, and activity. \\
${ }^{* *}$ Models adjusted for age, gender and baseline CD4 cell count, baseline viral load, total \\
dietary kcal, and activity \\
a Statistically significant, $P<.05$ \\
b $\mathrm{HR=Hazard} \mathrm{Ratio}$ \\
${ }^{\circ} \mathrm{Cl}=$ Confidence Interval
\end{tabular}




\section{References}

1. Shor-Posner G, Campa A, Zhang G, et al. When obesity is desirable: a longitudinal study of the Miami HIV-1-infected drug abusers (MIDAS) cohort. J Acquir Immune Defic Syndr 2000;23:81-88.

2. Shuter J, Chang CJ, Klein RS. Prevalence and predictive value of overweight in an urban HIV care clinic. J Acquir Immune Defic Syndr 2001;26:291-297.

3. Jones CY, Hogan JW, Snyder B, et al. Overweight and human immunodeficiency virus (HIV) progression in women: associations HIV disease progression and changes in body mass index in women in the HIV epidemiology research study cohort. Clin Infect Dis 2003;37:S69-S80.

4. Adeyemi OM, Vibhakar S, Evans AT. Obesity and lymphocyte subsets in virologically suppressed HIV-infected patients. Metabolism 2009;58:1285-1287.

5. Johnson KD, Cai B, Duffus W, et al. Longitudinal Association Between BMI at Diagnosis and HIV Disease Progression. AIDS Behav 2014;18:2249-2257. doi: 10.1007/s10461-014-0805-0.

6. Womack J, Tien PC, Feldman J, et al. Obesity and immune cell counts in women. Metabolism 2007;56:998-1004.

7. Crum-Cianflone NF, Roediger M, Eberly LE, et al. Impact of weight on immune cell counts among HIV-infected persons. Clin Vaccine Immunol 2011;18:940946. doi: 10.1128/CVI.00020-11.

8. Bogers RP, Bemelmans WJ, Hoogenveen RT, et al. Association of overweight with increased risk of coronary heart disease partly independent of blood pressure and cholesterol levels: a meta-analysis of 21 cohort studies including more than 300000 persons. Arch Intern Med 2007;167:1720-1728.

9. Sullivan PW, Morrato EH, Ghushchyan V, Wyatt HR, Hill JO. Obesity, inactivity, and the prevalence of diabetes and diabetes-related cardiovascular comorbidities in the U.S., 2000-2002. Diabetes Care 2005;28:1599-1603.

10. Calle EE, Rodriguez C, Walker-Thurmond K, Thun MJ. Overweight, obesity, and mortality from cancer in a prospectively studied cohort of U.S. adults. N Engl J Med 2003;348:1625-1638.

11. Razquin C, Marti A, Martinez JA. Evidences on three relevant obesogenes: MC4R, FTO and PPARy. Approaches for personalized nutrition. Mol Nutr Food Res 2011;55:136-149.

12. Chung WK, Leibi RL. Considerations regarding the genetics of obesity. Obesity (Silver Spring, MD) 2008;16:S33-S39. 
13. Frayling TM, Timpson NJ, Weedon MN, et al. A common variant in the FTO gene is associated with body mass index and predisposes to childhood and adult obesity. Science 2007;316:889-894.

14. Scuteri A, Sanna S, Chen WM, et al. Genome-wide association scan shows genetic variants in the FTO gene are associated with obesity-related traits. PLoS Genet 2007;3:e115.

15. Dina C, Meyre D, Gallina S, et al. Variation in FTO contributes to childhood obesity and severe adult obesity. Nat Genet 2007;39:724-726.

16. Gerken T, Girard CA, Tung YC, et al. The obesity-associated FTO gene encodes a 2-oxoglutarate-dependent nucleic acid demethylase. Science 2007 30;318:1469-1472.

17. Fredriksson R, Hägglund M, Olszewski PK, et al. The obesity gene, FTO, is of ancient origin, up-regulated during food deprivation and expressed in neurons of feeding-related nuclei of the brain. Endocrinology 2008;149:2062-2071.

18. Wåhlén K, Sjölin E, Hoffstedt J. The common rs9939609 gene variant of the fat mass- and obesity-associated gene FTO is related to fat cell lipolysis. 2008;49:607-611.

19. Kring SI, Holst C, Zimmermann E, et al. FTO gene associated fatness in relation to body fat distribution and metabolic traits throughout a broad range of fatness. PLoS ONE 2008;3:e2958.

20. Prevalence of HIV, total (\% of population ages 15-49). World Bank. Available at: http://data.worldbank.org/indicator/SH.DYN.AIDS.ZS. Accessed June 9, 2014.

21. Farahani $\mathrm{M}$, Vable $\mathrm{A}$, Lebelonyane $\mathrm{R}$, et al. Outcomes of the Botswana national HIVIAIDS treatment programme from 2002 to 2010: a longitudinal analysis. Lancet Glob Health 2014;2:e44-50. doi: 10.1016/S2214-109X(13)70149-9.

22. Walker AR, Adam F, Walker BF. World pandemic of obesity: the situation in Southern African populations. Public Health. 2001;115(6):368-372.

23. Letamo $\mathrm{G}$. The prevalence of, and factors associated with, overweight and obesity in Botswana. J Biosoc Sci 2011;43:75-84. doi: 10.1017/S0021932010000519.

24. Wrotniak BH, Malete L, Maruapula SD, et al. Association between socioeconomic status indicators and obesity in adolescent students in Botswana, an African country in rapid nutrition transition. Pediatr Obes 2012;7:e9-e13. doi: 10.1111/j.2047-6310.2011.00023.x.

25. Baum MK, Campa A, Lai S, et al. Effect of micronutrient supplementation on disease progression in asymptomatic, antiretroviral-naive, HIV-infected adults in Botswana: a randomized clinical trial. JAMA 2013;310:2154-2163. 
26. Lombard Z, Crowther NJ, van der Merwe L, Pitamber P, Norris SA, Ramsay M. Appetite regulation genes are associated with body mass index in black South African adolescents: a genetic association study. BMJ Open 2012;2. pii: e000873. doi: 10.1136/bmjopen-2012-000873.

27. Adeyemo A, Chen G, Zhou J, Shriner D, Doumatey A, Huang H, Rotimi C. FTO genetic variation and association with obesity in West Africans and African Americans. Diabetes 2010;59:1549-1554. doi: 10.2337/db09-1252.

28. Hennig BJ, Fulford AJ, Sirugo G, et al. FTO gene variation and measures of body mass in an African population. BMC Med Genet 2009;10:21. doi: 10.1186/14712350-10-21.

29. Zhao X, Yang Y, Sun BF, Zhao YL, Yang YG. FTO and obesity: mechanisms of association. Curr Diab Rep 2014;14:486. doi: 10.1007/s11892-014-0486-0.

30. Speakman JR, Rance KA, Johnstone AM. Polymorphisms of the FTO gene are associated with variation in energy intake, but not energy expenditure. Obesity 2008;16:1961-1965.

31. Cecil JE, Tavendale R, Watt P, et al. An obesity-associated FTO gene variant and increased energy intake in children. N Engl JMed 2008;359:2558-2566.

32. Wardle J, Llewellyn C, Sanderson S, et al. The FTO gene and measured food intake in children. Int J Obes 2009;33:42-45.

33. Speakman JR. FTO effect on energy demand vs food intake. Nature. 2010;464:E1; discussion E2.

34. Lappalainen T, KolehmainenM, Schwab U, et al. Gene expression of FTO in human subcutaneous adipose tissue, peripheral bloodmononuclear cells and adipocyte cell line. J Nutrigenet Nutrigenomics 2010;3:37-45.

35. Grunnet LG, Nilsson E, Ling C, et al. Regulation and function of FTO mRNA expression in human skeletal muscle and subcutaneous adipose tissue. Diabetes 2009;58:2402-2408.

36. Hjort J. Pre-colonial culture, post-colonial economic success? The Tswana and the African economic miracle. Econ Hist Rev 2010;63:688-709.

37. National Center for Biotechnology Center. dbSNP Short Genetic Variations: Reference SNP Cluster Report rs1421085. Available at: http://www.ncbi.nIm.nih.gov/projects/SNP/snp ref.cgi?rs=1421085. Assessed August 19, 2014.

38. Shor-Posner G, Campa A, Zhang G, et al. When obesity is desirable: a longitudinal study of the Miami HIV-1-infected drug abusers (MIDAS) cohort. J Acquir Immune Defic Syndr 2000;23:81-88. 
39. Shuter J, Chang CJ, Klein RS. Prevalence and predictive value of overweight in an urban HIV care clinic. J Acquir Immune Defic Syndr 2001;26:291-297.

40. Jones CY, Hogan JW, Snyder B, et al. Overweight and human immunodeficiency virus (HIV) progression in women: associations HIV disease progression and changes in body mass index in women in the HIV epidemiology research study cohort. Clin Infect Dis 2003;37:S69-S80.

41. Considine RV, Sinha MK, Heiman ML, et al: Serum imunorective-leptin concentrations in normal-weight and obese humans. N Engl J Med 1999;334:292-295.

42. Fantuzzi G, Faggioni R. Leptin in the regulation of immunity, inflammation and hematopoiesis. J. Leukoc. Biol 2000;68:437-446.

43. Loos RJ, Bouchard C. FTO: the first gene contributing to common forms of human obesity. Obes Rev 2008;9:246-250.

44. Kotler DP, Tierney AR, Wang J, Pierson RN. Magnitude of body cell mass depletion and the timing of death from wasting in AIDS. Am J Clin Nutr 1989;50:444-447.

45. Visnegarwala F, Raghavan SS, Mullin CM et al. Sex differences in the associations of HIV disease characteristics and body composition in antiretroviral-naive persons. Amer J Clin Nutr 2005;82:850-856.

46. Monda KL, Chen GK, Taylor KC et al. A Meta-Analysis Identifies New Loci Associated with Body Mass index in Individuals of African Ancestry. Nat Genet 2013;45:690-696. doi:10.1038/ng.2608. 


\title{
CHAPTER V: ASSOCIATION OF INFLAMMATORY MARKERS WITH HIV DISEASE PROGRESSION IN ART NAÏVE HIV+ ADULTS IN BOTSWANA
}

\begin{abstract}
Objective: This study evaluated the relationship between inflammatory markers including C-reactive protein, leptin, and bacterial endotoxin lipopolysaccharide (LPS) and body composition and HIV disease progression in HIV+ asymptomatic adults not on ART in Botswana over 18 months.

Methods: This is a retrospective analysis of data and specimens from a nutritional study, henceforth called parent study. Current study was conducted in 144 HIV+ ART naïve adults who were in the early stages of HIV disease in Botswana. CRP was measured by the parent study and plasma leptin and LPS were determined in a subset of 60 participants at baseline and 18 months. Linear and logistic multivariable regression analyses were conducted and adjusted for age, gender, smoking and body fat $\operatorname{mass} \%$.
\end{abstract}

Results: CRP was positively associated with BMI and waist circumference and inversely with CD4\%. Leptin had significant relationships with BMI, fat mass $\%$, and waist circumference. Higher HIV viral load was significantly associated with lower levels of leptin. LPS was inversely associated with BMI and fat mass \%. Higher levels of LPS were also associated with higher viral load.

Conclusions: HIV disease progression was predictive of inflammation and found to be independent of body fat. These findings suggest that at least one explanation for the obesity paradox may be accounted for by increased LPS and lower leptin among those with lower BMI which was associated with higher HIV viral load. The mechanisms 
affecting HIV disease progression through inflammation are complex and still not entirely understood, which warrants further prospective investigation.

Keywords: HIV infection, ART naïve, disease progression, CRP, leptin, LPS, inflammation 


\section{Introduction}

Chronic inflammation and immune activation are related to HIV disease progression as documented in the literature..$^{1-3}$ Inflammation is also associated with other HIV co-morbidities and non-HIV related complications such as cardiovascular and metabolically-related diseases/conditions. ${ }^{4-6}$ Inflammation is involved in the depletion of T-cells, and chronic immune activation drives the general and HIV-specific losses of immune function. ${ }^{7}$ Continuous inflammation induces pro-inflammatory cytokines which has been shown to produce thymic and T cell progenitor dysfunction. ${ }^{8}$ It has also been shown that triggered or activated CD4 cells are favored targets for viral infection and replication. Inflammation can also set up non-infected CD4 cells and other immune cells for death by programmed cell death or apoptosis. ${ }^{9}$ The biomarkers of inflammation examined in this study were C-reactive protein, leptin, and lipopolysaccharide (LPS).

Obesity is known to be associated with a chronic state of low grade inflammation. Inflammation in obesity is due to many mechanisms which include disordered secretion of adipokines within adipose tissue, resulting in insulin resistance and metabolic disorders. ${ }^{10}$ There seems to be controversy in the literature regarding obesity and inflammation and its relationship to HIV disease, which requires further research. A nutrition transition in sub-Saharan Africa is occurring with an increase in obesity, ${ }^{11}$ along with being the most affected region by the HIV epidemic. ${ }^{12}$ The interplay of body composition, inflammation and its effect on HIV disease progression warrant investigation to provide relevant clinical treatment for patients.

C-reactive protein or CRP is considered a sensitive systemic marker of inflammation and an acute phase reactant. ${ }^{13}$ Higher levels of CRP have also been associated with obesity and specifically abdominal obesity. ${ }^{14} \mathrm{CRP}>3 \mathrm{mg} / \mathrm{dL}$ has been associated with a higher risk for inflammation and mortality. ${ }^{15}$ In HIV, CRP has been 
shown to be a sensitive marker beyond cardiovascular disease ${ }^{16}$ it has been demonstrated to be an important predictor of higher risk of AIDS and mortality after ART initiation in ART naïve patients. ${ }^{17}$

Leptin is considered to be a pleiotropic molecule, with not only metabolic roles but also endocrine and immune regulation. ${ }^{18}$ In some studies, higher levels of leptin were found to be present during infection and inflammation; however, the results in human studies have been inconsistent in various diseases, including HIV. ${ }^{18}$ Leptin is involved in the proliferation of T- cells, including CD4 and CD8 cells. ${ }^{19}$ Higher levels of leptin have been found in obese individuals ${ }^{20}$ which may enhance the immunity through its role in proliferation and anti-apoptotic effects on lymphocytes. Leptin has been inversely associated with HIV viral load, independent of adipose tissue. ${ }^{21}$

Microbial translocation or bacterial products that crossed the gastrointestinal mucosa into circulation, is thought to have a role in persistent immune activation in HIV infection and can provoke pro-inflammatory reactions. ${ }^{22}$ Lipopolysacchride (LPS), an endotoxin, is a constituent of Gram-negative bacterial cell walls and known to produce proinflammatory responses. ${ }^{23}$ During HIV, microbial translocations may occur due to epithelial damage to the intestine, loss of T-helper-17 cells and a reduced removal of microbial products by phagocytes. ${ }^{22}$ Increased secretion of pro-inflammatory cytokines can also contribute to increased T cell activation and specifically can increase CD8 T cell activation and depletion of CD4 T cells. ${ }^{22}$ LPS has also been implicated in obesity and insulin resistance and high levels may affect inflammation and promote weight gain. ${ }^{25}$ Although microbial translocation is associated with immune activation and disease progression in developed countries, ${ }^{26-28}$ whether it contributes to HIV disease progression in African HIV+ individuals is not well understood. Sequestration of LPS by 
higher circulating lipoproteins in obesity has been suggested as mechanism for the obesity paradox ${ }^{29}$ and warrants further investigation in HIV.

Most of the studies looking at the relationship between inflammation and HIV have been conducted in settings where patients are taking ART, and mostly in developed nations. Both of these conditions may confound findings. Few longitudinal studies are available in African populations. The objective of this study was to evaluate over 18 months the relationship of inflammatory markers (C-reactive protein, leptin, and LPS) with body composition and laboratory markers of HIV disease infection and progression in HIV+ asymptomatic adults who are not receiving ART in Botswana.

\section{Methods}

\section{Study Design and Participants}

A retrospective study was conducted to examine data and specimens from 144 HIV-positive men $(n=34)$ and women $(n=110)$ from the placebo group of a multifactorial, randomized, double-blinded, placebo-controlled clinical trial in Botswana, which investigated whether supplementation with multivitamins and selenium could enhance immune function and delay the time to AIDS in ART naïve HIV+ adults. ${ }^{30}$ The study was conducted between December 2004 and July 2009. This parent study originally included 219 participants in the placebo group, however our retrospective study only included 144 participants with available data on high sensitivity C-reactive protein (hsCRP). The placebo group was used to avoid any confounding effects from the micronutrient supplementation on the outcome measures. Participants were eligible for the study with confirmation of HIV status, CD4 cell count $>350$ cells $/ \mu \mathrm{L}, \mathrm{BMI}>18 \mathrm{~kg} / \mathrm{m}^{2}$ for women and $18.5 \mathrm{~kg} / \mathrm{m}^{2}$ for men, age $\geq 18$ years, lack of a past history of AIDSdefining conditions, and were not participating in another blinded clinical trial or taking ART. Women were excluded if pregnant or had intention to become pregnant. All 
participants provided informed consent and approval to use their stored blood for future studies. Participants were recruited from the Botswana-Harvard AIDS Initiative Partnership (BHP) in Gaborone, Botswana. We obtained approval to use their stored blood for leptin and LPS from the Florida International University Institutional Review Board (IRB), the Harvard School of Public Health IRB and the Botswana Health Research Unit of the National Ministry of Health.

\section{Clinical Data}

At baseline and every three months, physical examination and medical history were performed by a trained nurse or a physician. Anthropometrics were also obtained and body mass index (BMI) was calculated by dividing the participants' weight in kg by their height in meters ${ }^{2}$. Waist and hip circumference was measured using a nonstretchable tape measure and following standardized procedures. Waist circumference was measured at the narrowest part of the waist between the lowest rib and the iliac crest and the hip circumference at the widest portion of the buttocks. Bioelectrical impedance analysis (BIA) was measured using the Biodynamics body composition analyzer (model BIA-310; Biodynamics Corp., Seattle, WA), which provides a print-out of measured impedance and calculated body fat and lean mass. Subjects were measured without shoes and socks, and electrodes were placed on the participant's right hand and wrist and right foot and ankle. Morbidity information was collected by questionnaires at screening, and at every monthly visit, and confirmed by documentation in the medical chart. Participants received their medical care in the same facilities to improve retention.

\section{Laboratory Data}

At baseline and every six months, blood was also drawn to evaluate HIV viral load, lipid panel, and blood chemistry. Every three months blood was drawn for CD4 and CD8 cell counts. The remaining plasma was centrifuged, aliquoted into cryovials and 
stored at $-80^{\circ} \mathrm{C}$ for future studies. Lymphocyte phenotype was determined with a fourcolor immunophenotyping panel of monoclonal antibodies. Differential counts were determined using a Coulter MaxM hematology instrument and corroborated with cytocentrifuge smears. HIV-viral load was determined using an in-vitro nucleic acid amplification test (Amplicor reagents and protocol, Roche-Diagnostics, Branchburg, NJ).

\section{Inflammatory Markers}

A total of 144 participants had high sensitivity-C reactive protein (hs-CRP) levels from the parent study that was analyzed using protein-latex assay (Roche, Basel, Switzerland) in the Botswana-Harvard HIV Reference Laboratory in Gaborone,

Botswana. A subset of 60 participants were randomly selected with available samples to measure plasma leptin and LPS levels at baseline and 18 months. Plasma leptin levels were measured using the Quantikine Human Leptin Immunoassay kit by R\&D systems (Minneapolis, MN, USA), a sandwich ELISA designed to measure soluble human leptin in plasma, according to manufacturer's instructions. Plasma LPS or endotoxin levels were measured using the Limulus Amebocyte Lysate ( $L A L)$ by Lonza (Walksersville, MD, USA), a chromogenic quantitation of bacterial endotoxin, according to manufacturer's instructions with the following modifications: Samples were diluted 1:20 with endotoxin-free water to avoid interference with background color and preheated to $70^{\circ} \mathrm{C}$ for 10 minutes prior to analyses to inactivate plasma proteins. Duplicates were assessed for each sample, for both leptin and LPS. The coefficient of variation or CV\% was calculated and CVs greater than $10 \%$ were reanalyzed.

\section{Statistical Analysis}

Laboratory markers of HIV infection and disease progression included in the analyses were CD4 cell count, CD4\%, CD8 cell count, CD8\%, CD4/CD8 ratio and HIV viral load. Descriptive statistics such as frequencies, percentages, medians and 
interquartile ranges were used to characterize the participants at baseline and its relation between laboratory markers of HIV infection and inflammatory markers. Mann Whitney $\mathrm{U}$ was used to determine differences in laboratory markers of HIV infection and body composition between the BMI groups and by inflammatory marker groups. BMI was stratified into two groups: Group 1: normal weight $\left(\mathrm{BMI}=18.0-24.9 \mathrm{~kg} / \mathrm{m}^{2}\right)$ and Group 2: overweight/obese $\left(\mathrm{BMI}=\geq 25 \mathrm{~kg} / \mathrm{m}^{2}\right)$ for the statistical analyses. Viral load was also stratified into $<4 \log _{10}$ copies $/ \mathrm{mL}$ or 10,000 copies $/ \mathrm{mL}$ and $\geq 4 \log _{10}$ copies $/ \mathrm{mL}$ as a measure of further disease progression and infectivity. ${ }^{31,32}$ Linear and logistic regressions were used to assess the relationship between body composition, laboratory markers of HIV infection, and inflammatory markers. The linear multivariable regression analysis also included a measure to check for multicollinearity known as variance inflation factor (VIF). All models had a VIF $<5$, therefore multicollinearity was ruled out. Multicollinearity was also checked for the logistic regression models and variables with correlations $r>.75$ were not included. Models were adjusted for covariates that included age, gender, smoking and fat mass\%. Logistic regression models included dependent inflammatory markers at the following cut-offs: hs-CRP $<$ or $\geq 3 \mathrm{mg} / \mathrm{L}$; leptin $<$ or $\geq$ median and LPS $<$ or $\geq$ median. Smoking tobacco was used a covariate since it has immunomodulatory effects and may affect T-cell activation. ${ }^{33,34}$ Variables that were not normally distributed were natural log transformed, except for CD4 and CD8 cell counts that were square-root transformed. For all analyses, a two sided test was used and $\mathrm{P}<0.05$ was considered statistically significant. Statistical analyses was completed using SPSS version 21. 


\section{Results}

\section{Demographics}

Table 1 displays the demographics of the population included for the analyses conducted below. In summary, the median age was 33 years with an IQR of 29-39 years and $76.40 \%$ were women. The median CD4 cell count and HIV viral load were 409.03 (IQR: 329.79-552.58) and 4.33 (IQR:3.58-4.83), respectively. The inter-assay CV for Leptin was 7.45 and for LPS $4.38 \%$. The intra-assay CV for leptin ranged between $6.76-8.69 \%$ and for LPS between $2.41-5.87 \%$.

\section{Spearman Correlations}

A positive correlation was seen between hs-CRP and leptin $(r=.404, P=.010)$ (Table 2). Leptin was also correlated with LPS ( $r=.357, P=.005)$. There was no significant correlation between hs-CRP and LPS. Hs-CRP was not correlated with measures of body composition and HIV disease progression. However, trends were seen between hs-CRP and BMI, waist circumference, lean body mass and fat mass. Strong positive correlations were observed between leptin and BMI $(r=.734, P<.001)$, waist circumference $(r=.603, p<.001)$ and fat mass $\%(r=.838, P<.001)$. LPS was inversely correlated with $\mathrm{BMI}(r=.288, P=.025)$, waist circumference $(r=.493, P=.003)$ and fat mass $\%(r=.362, P=.004)$. Lean mass $\%$ was inversely correlated with leptin $(r=-$ $.836, P<.001)$ and LPS ( $r=-.361, P=.005)$. No correlations were observed between inflammatory markers and laboratory markers of HIV infection. The correlations between LPS and CD8\% and viral load were approaching significance at $r=.253, P=.052$ and $r=.246, P=.060$, respectively.

\section{Relationship between BMI and Inflammatory Markers}

BMI was categorized into two groups: normal BMI $\left(18.0-24.9 \mathrm{~kg} / \mathrm{m}^{2}\right)$ and overweight/obese BMI ( $\left.\geq 25 \mathrm{~kg} / \mathrm{m}^{2}\right)$ and its association with inflammatory markers were 
examined. Those who were overweight/obese had higher median (IQR) levels of hsCRP $(P=.028)$ and leptin $(P<.001)$ compared to the normal BMl group, (Table 3).

Conversely, lower levels of LPS were seen in the overweight/obese group compared to the normal BMI group $(P=.001)$.

\section{Inflammatory Markers, Body Composition and Laboratory Markers of HIV Infection}

Table 4 demonstrates that having a CRP at or above $3 \mathrm{mg} / \mathrm{L}$ is associated with higher median (IQR) of waist circumference $(P=.036)$, and CD8 cell count $(P=.030)$ and lower levels of CD4\% $(P=.013)$, and CD4/CD8 ratio $(P=.015)$. A trend was observed in the relationship of having a hs-CRP $\geq 3 \mathrm{mg} / \mathrm{L}$ and higher CD8\% ( $P=.078)$. As shown on Table 5 , those who had higher median levels of leptin $(\geq 13,304 \mathrm{pg} / \mathrm{mL})$ had higher median $(\mathrm{IQR}) \mathrm{BMI}(P<.001)$, waist circumference $(P=.003)$, and fat mass $(P<.001)$. Levels below the median of leptin, were associated with higher lean body mass $(P<.001)$. None of the parameters for HIV disease progression were significantly associated with median levels of leptin. Having LPS levels below the median $(<.0582$ $\mathrm{EU} / \mathrm{mL})$ were significantly related to higher BMI $(P=.001)$, waist circumference $(P=.005)$, and fat mass $\%(P=.002)$ (Table 6$)$. Levels above the median were associated with higher viral load $(P=.023)$ and lean body mass \% $(P=.002)$.

\section{Regression Analyses of Inflammatory Markers and Laboratory Markers of HIV Infection and Disease Progression}

Linear regression models were conducted to examine the relationship of body composition and HIV disease progression markers with hs-CRP, leptin, and LPS at baseline, 18 months and the change over 18 months. All models were adjusted for age, gender, smoking and fat mass\%. Log transformed BMI at baseline was the only

measure of body composition associated with continuous hs-CRP at baseline $(\beta=1.905$; $95 \% \mathrm{Cl}=.281,3.530 ; P=.022$ ) (Table 7 ). No markers of HIV infection were associated 
with continuous hs-CRP at baseline or 18 months. Log transformed leptin was associated with continuous $\mathrm{BMI}$ at baseline $(\beta=1.764 ; 95 \% \mathrm{Cl}=.788,2.739 ; P=.022)$ and 18 months $(\beta=2.739 ; 95 \% \mathrm{Cl}=1.133,3.075, P<.001)$ (Table 8). Higher leptin was also associated with higher fat mass $\%$ at baseline $(\beta=.112 ; 95 \% \mathrm{Cl}=.090, .135 ; P<.001)$ and 18 months $(\beta=.403 ; 95 \% \mathrm{Cl}=.017, .069 ; P=.002)$. For every unit increase in transformed leptin there was a significant 2.103 unit increase in waist circumference at 18 months $(\beta=2.103 ; 95 \% \mathrm{Cl}=.806,3.400 ; P=.002)$. Having a viral load of $<4 \log _{10}$ copies $/ \mathrm{mL}$ was associated with higher leptin levels $(\beta=-.305 ; 95 \% \mathrm{Cl}=-.579,-.031$; $P=.030$ ) at baseline. Only waist circumference at baseline had a significant relationship with log transformed LPS $(\beta=-1.940 ; 95 \% \mathrm{Cl}=-3.397, .483 ; P=.011)$ (Table 9).

A separate linear regression analysis stratified by BMI groups was conducted. In those who had a BMI $\geq 25 \mathrm{~kg} / \mathrm{m}^{2}$, higher log transformed leptin was associated with lower viral load $(\beta=-.205 ; 95 \% \mathrm{Cl}=-3.94,-.016 ; P=.035)$ at baseline.

$\mathrm{Hs}-\mathrm{CRP} \geq 3 \mathrm{mg} / \mathrm{L}$ was significantly related to higher BMI at baseline $(\mathrm{OR}=60.960 ; 95 \% \mathrm{Cl}=2.784,1334.723 ; P=.009)$, waist circumference at 18 months $(\mathrm{OR}=98.811 ; 95 \% \mathrm{Cl}=1.697,5755.086 ; P=.027), \mathrm{CD} 4 \%$ at baseline $(\mathrm{OR}=.949 ; 95 \% \mathrm{Cl}=$ .902, .998; $P=.042$ ) (Table 10) and waist circumference over 18 months (OR=65.078; 95\% Cl: 1.490, 2842.157; $P=.030)$. Lower CD8 count change over 18 months was associated with $\mathrm{CRP} \geq 3 \mathrm{mg} / \mathrm{L}(\mathrm{OR}=.906 ; 95 \% \mathrm{Cl}=.831, .988 ; P=.025)$. A trend association was seen in the relationship between $\mathrm{hs}-\mathrm{CRP} \geq 3 \mathrm{mg} / \mathrm{L}$ and $\mathrm{BMI} \geq 25 \mathrm{~kg} / \mathrm{m}^{2}$ $(\mathrm{OR}=2.407 ; 95 \% \mathrm{Cl}=.941,6.156 ; P=.067)$. Leptin above the median $(13,304 \mathrm{pg} / \mathrm{mL})$ was related to several body composition measures at baseline and 18 month; however, there were no association with measures of HIV disease progression (Table 11). Leptin above the median was associated with a higher odds of having higher BMI at baseline $(\mathrm{OR}=2.073 ; 95 \% \mathrm{Cl}=1.194,3.601 ; P=.010)$ and 18 months $(\mathrm{OR}=1.554 ; 95 \% \mathrm{Cl}=1.125$, 
2.146; $P=.008$ ). Overweight/obese BMI category was also associated with leptin above the median at baseline $(\mathrm{OR}=58.572,95 \% \mathrm{Cl}=2.187,1568.688 ; P=.015)$ and 18 months $(\mathrm{OR}=79.634 ; 95 \% \mathrm{Cl}=4.607,1376.659 ; P=.003)$. Additionally, a higher odds of having more fat mass $\%$ was seen in the group that had leptin levels at or above the median at baseline $(\mathrm{OR}=1.580,95 \% \mathrm{Cl}=1.214,2.055 ; P=.001)$ and 18 months $(\mathrm{OR}=1.231 ; 95 \%$ $\mathrm{Cl}=1.070,1.416 ; P=.004)$. The likelihood of higher leptin increased with higher waist circumference $(\mathrm{OR}=1.267 ; 95 \mathrm{Cl}=1.016,1.580 ; P=.036)$. Leptin above the median was also associated with having an increase in CD4\% over 18 months (OR1.456; 95\% $\mathrm{Cl}=1.456,1.025,2.069 ; P=.036)$. Lastly, Table 12 displays the relationships between body composition and laboratory markers of HIV infection and disease progression for those at or above the median of LPS (.0582 EU/mL). BMI and having BMI $\geq 25 \mathrm{~kg} / \mathrm{m}^{2}$ was protective of having LPS above the median at baseline $(\mathrm{OR}=.790,95 \% \mathrm{Cl}=.630$, $.990 ; P=.041$; and $\mathrm{OR}=.035,95 \% \mathrm{Cl}=.004, .283 ; P=.002$, respectively) and $\mathrm{BMI}$ at 18 months $(\mathrm{OR}=.799,95 \% \mathrm{Cl}=.655, .976 ; P=.028)$. Fat mass $\%$ was also shown to be protective of having higher LPS at baseline $(\mathrm{OR}=.852,95 \% \mathrm{Cl}=.757, .958 ; P=.007)$. At baseline LPS at or above the median was associated with higher viral load $(O R=2.608$, $95 \% \mathrm{Cl}=1.111,6.124 ; P=.028)$ and having a viral load $\geq 4 \log _{10} \operatorname{copies} / \mathrm{mL}(\mathrm{OR}=8.005$, $95 \% \mathrm{Cl}=1.762,36.357 ; P=.007)$. The relationships between LPS as a continuous variable and viral load $\geq 4 \log _{10}$ copies/mL was approaching significance $(O R=3.776$, $95 \% \mathrm{Cl}=.959,14.869 ; P=.057)$.

\section{Discussion}

The results presented here suggest a strong association between inflammatory markers and body composition and HIV disease progression in ART naïve adult participants in Botswana. To our knowledge, no study has assessed leptin or LPS in a population from Botswana with or without HIV infection. 
CRP has previously been shown to be associated with CD4 cell count and HIV viral load in ART naïve HIV+ adults. ${ }^{35-37}$ Our study did not confirm these associations with measures of HIV disease progression, except for CD4\%. CRP levels $\geq 3 \mathrm{mg} / \mathrm{L}$ were associated with lower CD4\%. CD4\% is considered to be a more stable measure than absolute CD4 cell counts and is thought to provide a better prognostic information before ART is initiated in HIV infection. ${ }^{38,39}$ Thus, this study showed that CD4\%, as a measure of HIV disease progression, was an independent predictor of higher CRP levels after adjusting for age, gender, smoking and fat mass $\%$.

CRP and its association with mortality were investigated in HIV+ populations in Botswana; ${ }^{40,41}$ however, these previous reports did not asses its relationship with parameters of disease progression such as CD4 cell count or viral load. CRP levels were found to be higher 4 weeks after initiation of ART in patients who died compared to those who survived, in another HIV+ adult cohort in Botswana. ${ }^{40}$ Baseline levels of CRP were also higher in those who died after ART initiation compared to matched controls in Botswana. $^{41}$

Azzoni et al. ${ }^{21}$ was the first to show that leptin levels were inversely associated with viral replication independent of the amount of adipose tissue. Their cohort of exclusively ART naïve women from South Africa also demonstrated an association between viral load and immune activation. We confirmed an inverse relationship between leptin levels and viral load at baseline, independent of body fat. These associations were found in HIV+ male and female participants. These results are in agreement with those of Azzoni and colleagues ${ }^{21}$ who hypothesized that high viral replication and immune activation could result in chronic inflammation that would cause lipoatrophy, therefore, lowering leptin levels. 
Leptin is involved in the proliferation of CD4 and CD8 cells, ${ }^{42}$ however, we did not find any significant relationships between leptin and CD4 or CD8 cell counts, even while adjusting for fat mass $\%$. However, leptin above the median was associated with a greater increase in CD4\% over 18 months. Other researchers ${ }^{21,43,44}$ examining leptin in HIV+ ART naïve individuals did not find significant relationship with CD4 cell counts.

The lack of an association of CD4 cell count and leptin may be due to the early stage of the disease and healthier status in these participants. The parent study's enrollment criteria included having CD4 $\geq 350$ cells $/ \mu \mathrm{L}$ and $\mathrm{BMI}>18 \mathrm{~kg} / \mathrm{m}^{2}$, which may have precluded the chance of examining the associations with lower levels of CD4 counts and $\mathrm{BMI}$ in the range of undernutrition at baseline. Additionally, ART-naïve participants usually present uncontrolled viral loads.

Previous studies evaluating LPS and HIV disease progression in ART naïve HIV+ adults have shown conflicting findings. In a cohort of HIV-positive, ART-naïve adults, Marchetti el al. ${ }^{28}$ reported a significant relationship between LPS and disease progression as a composite outcome that included, AIDS defining conditions, death, CD4 cell counts $<200$ cells $/ \mu \mathrm{L}$, or start of ART in HIV+ ART naïve adults, who were followed for approximately 3 years. This relationship was independent of CD4 cell counts and HIV viral load. Conversely, a study examining LPS and HIV disease progression in ART naïve Ugandans and Americans was not able to detect sufficient LPS levels in their samples for analyses. ${ }^{45}$ A recent study conducted in Kenyan women demonstrated that LPS levels were associated with chronic HIV infection, whether treated or not with ART; however, no direct associations with CD4 cell count or viral load was found. ${ }^{46}$ This present study did not find a significant association between LPS and CD4 cell count, but LPS was significantly and inversely associated with viral load. LPS levels above the median were associated with higher viral load and those with LPS levels $\geq$ the median 
were 8 times more likely to have viral load $>4 \log _{10}$ copies $/ \mathrm{mL}$ or 10,000 copies $/ \mathrm{mL}$. Interestingly, LPS was also inversely associated with measures of body composition, therefore being overweight or obese was protective of having higher levels of LPS. Timmons et al. ${ }^{47}$ did not show significant association between LPS and body composition; however, they did report relationship with sCD14. Soluble CD14 is a measure of microbial translocation, which is freed from monocytes by LPS stimulation. ${ }^{48}$ There was an inverse association between SCD14 and limb and trunk fat in 178 HIV+ adults that included ART treated and non-treated patients. The authors suggest that microbial translocation may be involved in muscle and fat loss during HIV disease. Unfortunately, the result could not be separated from the effect of ART treatment since the analyses included both ART treated and non-treated. In animals, it has been demonstrated that the quality of diet, rather than weight, was a better predictor of the composition of intestinal bacteria. ${ }^{49} \mathrm{~A}$ high fat diet has been shown to be associated with higher LPS levels. ${ }^{50}$ Diet composition of those with a higher BMI may have affected inflammation and should be researched further.

A possible explanation for the lower levels of LPS observed in those with higher BMI might be the endotoxin lipoprotein hypothesis. Rauchhaus et al. ${ }^{29}$ were the first to describe the endotoxin-lipoprotein hypothesis as a way to explain the paradox of higher cholesterol levels being beneficial in congestive heart failure. Higher circulating lipoproteins may modulate inflammation by binding to lipopolyssachrides and reduce their effect on release of proinflammatory cytokines. LPS is sequestered during micelle creation under the direction of lipoproteins. Since higher BMI is associated with higher risk of elevated cholesterol, triglycerides and LDL, ${ }^{51,52}$ more circulating lipoproteins may be available to capture LPS. 
The limitations of our study include the study design, which was retrospective and observational. A larger sample size may have also showed significant relationships between inflammatory markers and disease progression. A selection bias may also have been present since we chose to complete leptin and LPS in a random subset that had samples available at baseline and 18 months. In HIV, bioimpedance (BIA) has been shown to be an effective method for detecting fat mass; ${ }^{53}$ however, BIA has limitations, since its values can be influenced by body arrangement, hydration, ingestion of food and drinks, air and body temperature and exercise. ${ }^{54}$ Our BIA measurement protocol countered these limitations by giving detailed instructions to the participants on their preparation for their visit, and standardizing the measurement parameters.

\section{Conclusions}

Body composition and HIV disease progression affected inflammation in this HIV+ adult population in Botswana, early in their disease. Laboratory markers of HIV infection and disease progression was predictive of inflammation, independent of body fat. Higher LPS was associated with lower BMI and higher viral load, while higher leptin was associated with higher fat mass and lower viral load. These are new and thoughtprovoking findings that might help explain the obesity paradox often observed in HIV+ ART adults. The mechanisms affecting HIV disease progression through inflammation are complex and still not entirely understood, which warrants further prospective investigation before and after initiation of ART.

\section{Acknowledgements}

The parent study was funded by the National Institute on Drug Abuse (R01-DA-16551). The laboratory analyses was supported by the CDR Diversity Scholarship provided by the Academy of Nutrition and Dietetics and Adolfo Henriquez Scholarship. We thank all 
of the participants in the study without whom advancement in the nutritional management of the HIV disease are not possible. 
Table 1: General Characteristics of the Sample Population

\begin{tabular}{|c|c|}
\hline Variable & $\begin{array}{c}\text { Total } \\
(\mathrm{N}=144)\end{array}$ \\
\hline Age (years) & $33.00(29.00-39.00)$ \\
\hline \multicolumn{2}{|l|}{ Gender ${ }^{a}$} \\
\hline Male (\%) & $34(23.60)$ \\
\hline Female (\%) & $110(76.40)$ \\
\hline BMI $\left(\mathrm{kg} / \mathrm{m}^{2}\right)$ & $22.70(20.70-26.93)$ \\
\hline Waist (inches) & $32.28(29.92-35.81)$ \\
\hline Waist to hip ratio & $.82(.79-.88)$ \\
\hline Lean mass (\%) & $71.30(66.30-76.00)$ \\
\hline Fat mass $(\%)$ & $28.70(24.00-33.70)$ \\
\hline CD4 cell count (cells/ $\mu \mathrm{L})$ & 409.03 (329.79-552.58) \\
\hline CD4 \% & $26.35(19.64-31.04)$ \\
\hline CD8 cell count (cells/ $\mu \mathrm{L})$ & 844.35 (621.96-1189.17) \\
\hline CD8 \% & $51.70(43.58-58.30)$ \\
\hline CD4/CD8 Ratio & $.53(.36-.68)$ \\
\hline HIV viral load ( $\log _{10}$ copies $/ \mathrm{mL}$ ) & $4.33(3.58-4.83)$ \\
\hline $\mathrm{CRP}(\mathrm{mg} / \mathrm{L})$ & $1.69(.80-4.74)$ \\
\hline Leptin $(\mathrm{pg} / \mathrm{mL})^{\mathrm{b}}$ & $13,304.75(5649.13-24,430.50)$ \\
\hline LPS $(E U / m L)^{b}$ & $.058(.053, .068)$ \\
\hline
\end{tabular}


Table 2: Baseline Spearman Correlation Coefficients and $P$-values

\begin{tabular}{|c|c|c|c|}
\hline Variables & CRP & Leptin $^{a}$ & $\mathrm{LPS}^{\mathrm{a}}$ \\
\hline $\mathrm{CRP}(\mathrm{mg} / \mathrm{L})$ & - & $\begin{array}{c}r=.404 \\
p=.010^{* *}\end{array}$ & $\begin{array}{l}r=-.042 \\
p=.796\end{array}$ \\
\hline Leptin $(\mathrm{pg} / \mathrm{mL})$ & $\begin{array}{c}r=.404 \\
p=.010^{\star *}\end{array}$ & - & $\begin{array}{l}r=-.357 \\
p=.005^{* *}\end{array}$ \\
\hline LPS (EU/mL) & $\begin{array}{l}r=-.042 \\
p=.796\end{array}$ & $\begin{array}{c}r=-.357 \\
p=.005^{\star *}\end{array}$ & - \\
\hline BMI $\left(\mathrm{kg} / \mathrm{m}^{2}\right)$ & $\begin{array}{l}r=.150 \\
p=.073\end{array}$ & $\begin{array}{c}r=.734 \\
p<.001^{* *}\end{array}$ & $\begin{array}{l}r=-.288 \\
p=.025^{*}\end{array}$ \\
\hline Waist (inches) & $\begin{array}{l}r=.179 \\
p=.072\end{array}$ & $\begin{array}{c}r=.603 \\
p<.001^{* *}\end{array}$ & $\begin{array}{c}r=-.493 \\
p=.003^{* *}\end{array}$ \\
\hline Waist-to-hip ratio & $\begin{array}{l}r=.151 \\
p=.129\end{array}$ & $\begin{array}{l}r=-.023 \\
p=.895\end{array}$ & $\begin{array}{l}r=.082 \\
p=.638\end{array}$ \\
\hline Lean body mass (\%) & $\begin{array}{l}r=-.154 \\
p=.066\end{array}$ & $\begin{array}{l}r=-.836 \\
p<.001^{* *}\end{array}$ & $\begin{array}{c}r=.361 \\
p=.005^{* *}\end{array}$ \\
\hline Fat mass (\%) & $\begin{array}{l}r=.155 \\
p=.065\end{array}$ & $\begin{array}{c}r=.838 \\
p<.001^{* *}\end{array}$ & $\begin{array}{l}r=-.362 \\
p=.004^{* *}\end{array}$ \\
\hline CD4 cell count (cells/ $\mu \mathrm{L})$ & $\begin{array}{l}r=-.083 \\
p=.647\end{array}$ & $\begin{array}{l}r=.005 \\
p=.969\end{array}$ & $\begin{array}{l}r=.015 \\
p=.912\end{array}$ \\
\hline CD4\% & $\begin{array}{l}r=-.144 \\
p=.175\end{array}$ & $\begin{array}{l}r=-.044 \\
p=.740\end{array}$ & $\begin{array}{l}r=-.134 \\
p=.308\end{array}$ \\
\hline CD8 cell count (cells/ $\mu \mathrm{L})$ & $\begin{array}{l}r=.088 \\
p=.294\end{array}$ & $\begin{array}{l}r=-.090 \\
p=.496\end{array}$ & $\begin{array}{l}r=.157 \\
p=.232\end{array}$ \\
\hline CD8\% & $\begin{array}{l}r=.076 \\
p=.365\end{array}$ & $\begin{array}{l}r=-.240 \\
p=.065\end{array}$ & $\begin{array}{l}r=.253 \\
p=.052\end{array}$ \\
\hline CD4/CD8 Ratio & $\begin{array}{l}r=-.104 \\
p=.216\end{array}$ & $\begin{array}{l}r=.096 \\
p=.464\end{array}$ & $\begin{array}{l}r=-.134 \\
p=.308\end{array}$ \\
\hline HIV viral load ( $\log _{10}$ copies $\left./ \mathrm{mL}\right)$ & $\begin{array}{l}r=.092 \\
p=.271\end{array}$ & $\begin{array}{l}r=-.145 \\
p=.273\end{array}$ & $\begin{array}{l}r=.246 \\
p=.060\end{array}$ \\
\hline
\end{tabular}

${ }^{\mathrm{a}}$ Completed in a subset of 60 participants

${ }^{*} \mathrm{P}<0.05,{ }^{* *} \mathrm{P}<0.01$ 
Table 3: Relationship Between BMI Groups and Measures of Inflammatory Markers at Baseline* $^{*}$

\begin{tabular}{lccc}
\hline $\begin{array}{l}\text { Inflammatory } \\
\text { Markers }\end{array}$ & BMI $\left(18-24.9 \mathrm{~kg} / \mathrm{m}^{2}\right)$ & BMl $>25 \mathrm{~kg} / \mathrm{m}^{2}$ & $P$-value \\
\hline CRP $(\mathrm{mg} / \mathrm{L})^{\mathrm{a}}$ & $1.41(.70-4.15)$ & $2.37(1.20-5.89)$ & $.028^{\mathrm{c}}$ \\
${\text { Leptin }(\mathrm{pg} / \mathrm{mL})^{\mathrm{b}}}$ & $5,687.05(2,799.63-$ & $22,894.90(14,147.43-$ & $<.001^{\mathrm{c}}$ \\
& $11,366.73)$ & $33,943.33)$ & \\
LPS $(\mathrm{EU} / \mathrm{mL})^{\mathrm{b}}$ & $.068(.061-.079)$ & $.055(.053-.058)$ & $.001^{\mathrm{c}}$ \\
\hline
\end{tabular}

${ }^{*}$ Data reported as median (interquartile range)

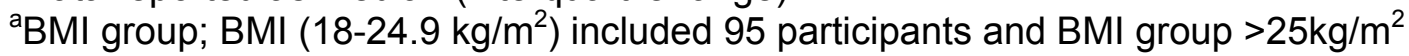
included 49

${ }^{\mathrm{b}} \mathrm{BMI}$ group; BMI $\left(18-24.9 \mathrm{~kg} / \mathrm{m}^{2}\right)$ included 30 participants and BMI group $>25 \mathrm{~kg} / \mathrm{m}^{2}$ included 30

'Statistically significant, $P<.05$ 
Table 4: Relationship Between CRP Groups and Body Composition and Measures of Inflammatory Markers at Baseline*

\begin{tabular}{|c|c|c|c|}
\hline Variables & $\mathrm{CRP}<3 \mathrm{mg} / \mathrm{L}$ & $\mathrm{CRP} \geq 3 \mathrm{mg} / \mathrm{L}$ & $P$-value \\
\hline BMI $\left(\mathrm{kg} / \mathrm{m}^{2}\right)$ & $22.40(20.50-25.90)$ & $24.40(20.70-28.95)$ & .094 \\
\hline Waist (inches) & $31.79(29.92-34.44)$ & $33.86(30.71-38.29)$ & $.036^{a}$ \\
\hline Waist to hip ratio & $.81(.78-.88)$ & $.83(.80-.89)$ & .139 \\
\hline Lean mass (\%) & $71.70(67.20-75.90)$ & 69.25 (64.25-79.53) & .254 \\
\hline Fat mass $(\%)$ & $28.30(24.10-32.80)$ & 30.75 (20.48-35.78) & .248 \\
\hline $\begin{array}{l}\text { CD4 cell count } \\
(\text { cells } / \mu \mathrm{L})\end{array}$ & 419.05 (332.48-553.63) & 401.30 (323.92-555.39) & .591 \\
\hline CD4 \% & $27.56(22.02-31.56)$ & 22.95 (18.42-29.85) & $.013^{a}$ \\
\hline $\begin{array}{l}\text { CD8 cell count } \\
(\text { cells } / \mu \mathrm{L})\end{array}$ & 773.28 (586.65-1163.89) & $\begin{array}{c}925.36(712.48- \\
1213.74)\end{array}$ & $.030^{a}$ \\
\hline CD8 \% & $48.98(42.91-57.64)$ & $54.67(44.68-61.18)$ & .078 \\
\hline CD4/CD8 Ratio & $.56(.39-.71)$ & $.41(.29-.62)$ & $.015^{a}$ \\
\hline $\begin{array}{l}\text { HIV viral load } \\
\left(\log _{10} \text { copies } / m L\right)\end{array}$ & $4.14(3.47-4.82)$ & 4.57 (3.66-5.08) & .141 \\
\hline
\end{tabular}


Table 5: Relationship Between Median Groups of Leptin and Body Composition and Measures of Inflammatory Markers at Baseline*

\begin{tabular}{|c|c|c|c|}
\hline Variables & Leptin<13,304 pg/mL & Leptin $\geq 13,304 \mathrm{pg} / \mathrm{mL}$ & $P$-value \\
\hline BMI $\left(\mathrm{kg} / \mathrm{m}^{2}\right)$ & $21.30(20.00-23.60)$ & $27.10(25.60-31.10)$ & $<.001^{a}$ \\
\hline Waist (inches) & $30.51(29.82-35.04)$ & 36.24 (32.87-38.39) & $.003^{\mathrm{a}}$ \\
\hline Waist to hip ratio & $.83(.79-.90)$ & 35.24 (32.87-38.39) & .804 \\
\hline Lean mass (\%) & $75.50(69.85-80.40)$ & $64.40(62.40-66.00)$ & $<.001^{a}$ \\
\hline Fat mass $(\%)$ & $24.50(19.60-29.75)$ & $35.60(32.00-37.60)$ & $<.001^{a}$ \\
\hline $\begin{array}{l}\text { CD4 cell count } \\
(\text { cells } / \mu \mathrm{L})\end{array}$ & $394.41(318.82-478.95)$ & $393.17(316.36-543.87)$ & .842 \\
\hline CD4 \% & $24.74(19.22-28.60)$ & $23.60(18.92-30.04)$ & .988 \\
\hline $\begin{array}{l}\text { CD8 cell count } \\
(\text { cells } / \mu \mathrm{L})\end{array}$ & $941.90(677.67-1255.15)$ & $889.52(693.89-1271.36)$ & .912 \\
\hline CD8 \% & $54.75(47.93-61.33)$ & $48.37(41.06-61.06)$ & .108 \\
\hline CD4/CD8 Ratio & $.44(.32-.57)$ & $.47(.30-.75)$ & .589 \\
\hline $\begin{array}{l}\text { HIV viral load } \\
\left(\text { Log }_{10} \text { copies } / \mathrm{mL}\right)\end{array}$ & $4.31(3.64-4.87)$ & $4.06(3.50-4.60)$ & .275 \\
\hline
\end{tabular}


Table 6: Relationship Between Median Groups of LPS and Body Composition and Measures of Inflammatory Markers at Baseline*

\begin{tabular}{|c|c|c|c|}
\hline Variables & LPS<.0582 EU/mL & LPS $\geq .0582 \mathrm{EU} / \mathrm{mL}$ & $P$-value \\
\hline BMI $\left(\mathrm{kg} / \mathrm{m}^{2}\right)$ & $26.70(25.05-31.15)$ & $22.40(20.70-25.00)$ & $.001^{\mathrm{a}}$ \\
\hline Waist (inches) & 36.32 (34.35-39.37) & 31.50 (29.92-35.42) & $.005^{\mathrm{a}}$ \\
\hline Waist to hip ratio & $.80(.79-.87)$ & $.82(.78-.90)$ & .748 \\
\hline Lean mass (\%) & 64.70 (62.55-70.08) & $71.90(67.03-80.03)$ & $.002^{a}$ \\
\hline Fat mass $(\%)$ & $35.30(29.93-37.45)$ & $28.10(19.98-32.98)$ & $.002^{a}$ \\
\hline $\begin{array}{l}\text { CD4 cell count } \\
\text { (cells } / \mu \mathrm{L})\end{array}$ & $424.03(336.23-545.24)$ & 392.09 (311.12-459.95) & .301 \\
\hline CD4 \% & $24.14(19.16-30.34)$ & 23.75 (18.49-28.42) & .433 \\
\hline $\begin{array}{l}\text { CD8 cell count } \\
(\text { cells } / \mu \mathrm{L})\end{array}$ & $848.30(688.51-1276.73)$ & $\begin{array}{c}961.51(685.78- \\
1253.53)\end{array}$ & .412 \\
\hline CD8 \% & $48.13(42.73-59.26)$ & $54.81(47.65-62.10)$ & .089 \\
\hline CD4/CD8 Ratio & $.53(.32-.67)$ & $.44(.31-.61)$ & .375 \\
\hline $\begin{array}{l}\text { HIV viral load } \\
\left(\log _{10} \text { copies } / \mathrm{mL}\right)\end{array}$ & $3.93(3.15-4.46)$ & $4.36(3.92-4.82)$ & $.023^{a}$ \\
\hline
\end{tabular}


Table 7: Linear Regression at Baseline, 18 Months and the Change Over 18 Months by CRP*

\begin{tabular}{|c|c|c|c|c|c|c|c|c|c|}
\hline & \multicolumn{3}{|c|}{ Baseline } & \multicolumn{3}{|c|}{18 Months } & \multicolumn{3}{|c|}{ Change Over 18 Months } \\
\hline Variable & $\beta$ & $95 \% \mathrm{Cl}$ & $P$-value & $\beta$ & $95 \% \mathrm{Cl}$ & $P$-value & $\beta$ & $95 \% \mathrm{Cl}$ & $P$-value \\
\hline $\mathrm{BMI}^{\mathrm{b}}$ & 1.905 & $.281,3.530$ & $.022^{d}$ & .646 & $-1.839,3.131$ & .603 & .949 & $-2.579,4.477$ & .983 \\
\hline $\mathrm{BMI}>25 \mathrm{~kg} / \mathrm{m}^{2}$ & .398 & $-.143,939$ & .148 & .665 & $-.353,1.683$ & .195 & - & - & - \\
\hline Fat mass $\%^{\mathrm{a}}$ & .020 & $-.009, .050$ & .177 & .010 & $-.043, .062$ & .709 & .014 & $-.030, .057$ & .536 \\
\hline Waist $^{\mathrm{b}}$ & -.175 & $-2.316,1.965$ & .871 & 2.491 & $-1.108,6.090$ & .170 & 1.736 & $-.145,3.617$ & .070 \\
\hline CD4 cell count ${ }^{\mathrm{c}}$ & -.002 & $-.057, .053$ & .947 & .016 & $-.078, .111$ & .730 & -.027 & $-.114, .060$ & .536 \\
\hline CD4\% & -.013 & $-.041, .015$ & .368 & -.016 & $-.066, .034$ & .520 & .035 & $-.024, .093$ & .243 \\
\hline HIV viral load ${ }^{b}$ & .084 & $-.151, .320$ & .480 & .296 & $-.165, .756$ & .203 & .103 & $-.226, .432$ & .620 \\
\hline $\begin{array}{l}\text { HIV viral load } \\
\geq 4 \log _{10} \text { copies } / \mathrm{mL}\end{array}$ & .091 & $-.342, .523$ & .679 & .709 & $-.111,1.529$ & .089 & - & - & - \\
\hline CD8 cell count ${ }^{\mathrm{C}}$ & .008 & $-.019, .034$ & .565 & .025 & $-.027, .077$ & .335 & -.037 & $-.085, .012$ & .137 \\
\hline CD8\% & .004 & $-.017, .024$ & .709 & .008 & $-.029, .046$ & .650 & -.046 & $-.098, .006$ & .085 \\
\hline CD4/CD8 Ratio & -.169 & $-.952, .613$ & .669 & -.581 & $-2.080, .917$ & .438 & .737 & $-1.214,2.688$ & .455 \\
\hline
\end{tabular}

*Models adjusted for age, gender, smoking, and fat mass percentage

${ }^{a}$ Model adjusted for age, gender, and smoking

${ }^{\mathrm{b}}$ Log transformed

'Square root transformed

${ }^{\mathrm{d}}$ Statistically significant, $P<.05$ 
Table 8: Linear Regression at Baseline, 18 Months, and the Change Over 18 Months by Leptin*

\begin{tabular}{|c|c|c|c|c|c|c|c|c|c|}
\hline & \multicolumn{3}{|c|}{ Baseline } & \multicolumn{3}{|c|}{18 Months } & \multicolumn{3}{|c|}{ Change Over 18 Months } \\
\hline Variable & $\beta$ & $95 \% \mathrm{Cl}$ & $P$-value & $\beta$ & $95 \% \mathrm{Cl}$ & $P$-value & $\beta$ & $95 \% \mathrm{Cl}$ & $P$-value \\
\hline $\mathrm{BMI}^{\mathrm{b}}$ & 1.764 & $.788,2.739$ & $.001^{\mathrm{d}}$ & 2.104 & $1.133,3.075$ & $<.001^{\mathrm{d}}$ & .493 & $-1.463,2.450$ & .615 \\
\hline $\mathrm{BMI}>25 \mathrm{~kg} / \mathrm{m}^{2}$ & .584 & $.260, .908$ & $.001^{d}$ & .864 & $.498,1.230$ & $<.001^{\mathrm{d}}$ & - & 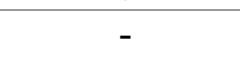 & - \\
\hline Fat mass $\%^{a}$ & .112 & $.090, .135$ & $<.001^{\mathrm{d}}$ & .043 & $.017, .069$ & $.002^{d}$ & -.016 & $-.057, .025$ & .437 \\
\hline Waist $^{\mathrm{b}}$ & .394 & $-1.546,2.333$ & .681 & 2.103 & $.806,3.400$ & $.002^{d}$ & .247 & $-1.073,1.567$ & .704 \\
\hline CD4 cell count ${ }^{\mathrm{C}}$ & .027 & $-.010, .065$ & .151 & -.016 & $-.062, .030$ & .495 & .026 & $-.036, .089$ & .402 \\
\hline CD4\% & .006 & $-.014, .026$ & .551 & -.003 & $-.028, .022$ & .816 & .020 & $-.010, .049$ & .194 \\
\hline HIV viral load ${ }^{b}$ & -.145 & $-.311, .022$ & .087 & -.129 & $-.335, .078$ & .217 & .107 & $-.177, .331$ & .344 \\
\hline $\begin{array}{l}\text { HIV viral load } \\
\geq 4 \log _{10} \text { copies } / \mathrm{mL}\end{array}$ & -.305 & $-.579,-.031$ & $.030^{d}$ & -.173 & $-.541, .194$ & .348 & - & - & - \\
\hline CD8 cell count ${ }^{\mathrm{C}}$ & .005 & $-.014, .024$ & .599 & -.008 & $-.031, .014$ & .459 & -.010 & $-.040, .019$ & .493 \\
\hline CD8\% & -.002 & $-.015, .010$ & .685 & .001 & $-.017, .017$ & .990 & -.019 & $-.044, .006$ & .140 \\
\hline CD4/CD8 Ratio & .156 & $-.429, .740$ & .595 & -.117 & $-.950, .716$ & .780 & .509 & $-.451,1.470$ & .292 \\
\hline
\end{tabular}

*Models adjusted for age, gender, smoking, and fat mass percentage

${ }^{a}$ Model adjusted for age, gender, and smoking

${ }^{\mathrm{b}}$ Log transformed

'Square root transformed

${ }^{\mathrm{d}}$ Statistically significant, $P<.05$ 
Table 9: Linear Regression at Baseline, 18 Months, and the Change Over 18 Months by LPS*

\begin{tabular}{|c|c|c|c|c|c|c|c|c|c|}
\hline & \multicolumn{3}{|c|}{ Baseline } & \multicolumn{3}{|c|}{18 Months } & \multicolumn{3}{|c|}{ Change Over 18 Months } \\
\hline Variable & $\beta$ & $95 \% \mathrm{Cl}$ & $P$-value & $\beta$ & $95 \% \mathrm{Cl}$ & $P$-value & $\beta$ & $95 \% \mathrm{Cl}$ & $P$-value \\
\hline $\mathrm{BMI}^{\mathrm{b}}$ & -.483 & $-1.208, .243$ & .188 & -.023 & $-.399 . .354$ & .904 & -2.979 & $-1.771, .822$ & .466 \\
\hline $\mathrm{BMI}<25 \mathrm{~kg} / \mathrm{m}^{2}$ & -.273 & $-.506,-.040$ & $.022^{d}$ & -.017 & $-.160, .127$ & .818 & - & - & - \\
\hline Fat mass $\%^{a}$ & .001 & $-.014, .016$ & .892 & .001 & $-.008, .009$ & .950 & .004 & $-.013, .020$ & .673 \\
\hline Waist $^{\mathrm{b}}$ & -1.940 & $-3.397,-.483$ & $.011^{\mathrm{d}}$ & -.005 & $-.477, .467$ & .982 & 051 & $-1.088,1.190$ & .927 \\
\hline CD4 cell count ${ }^{\mathrm{C}}$ & .009 & $-.017, .034$ & .509 & -.004 & $-.019, .011$ & .569 & .003 & $-.038, .045$ & .876 \\
\hline CD4\% & .003 & $-.011, .017$ & .648 & -.006 & $-.014, .002$ & .165 & -.010 & $-.030, .010$ & .319 \\
\hline HIV viral load ${ }^{b}$ & .054 & $-.059, .168$ & .337 & .047 & $-.020, .113$ & .168 & .012 & $-.135, .159$ & .869 \\
\hline $\begin{array}{l}\text { HIV viral load } \\
\geq 4 \log _{10} \text { copies } / \mathrm{mL}\end{array}$ & .121 & $-.067, .309$ & .201 & .064 & $-.056, .183$ & .289 & - & - & - \\
\hline CD8 cell count $^{\mathrm{C}}$ & .003 & $-.010, .016$ & .660 & .004 & $-.003, .011$ & .290 & .006 & $-.013, .026$ & .512 \\
\hline CD8\% & .003 & $-.005, .011$ & .432 & .001 & $-.004, .007$ & .643 & -.002 & $-.019, .015$ & .809 \\
\hline CD4/CD8 Ratio & .019 & $-.377, .415$ & .924 & -.193 & $-.458, .072$ & .150 & -.115 & $-.757, .526$ & .719 \\
\hline
\end{tabular}

*Models adjusted for age, gender, smoking, and fat mass percentage

${ }^{a}$ Model adjusted for age, gender, and smoking

${ }^{\mathrm{b}}$ Log transformed

'Square root transformed

${ }^{\mathrm{d}}$ Statitically significant, $P<.05$ 
Table 10: Logistic Regression at Baseline, 18 Months, and Change Over 18 Months by CRP Groups ( $<$ and $\geq 3 \mathrm{mg} / \mathrm{L})^{*}$

\begin{tabular}{|c|c|c|c|c|c|c|c|c|c|}
\hline & \multicolumn{3}{|c|}{ Baseline } & \multicolumn{3}{|c|}{18 Months } & \multicolumn{3}{|c|}{ Change Over 18 Months } \\
\hline Variable & OR & $95 \% \mathrm{Cl}$ & $P$-value & OR & $95 \% \mathrm{Cl}$ & $P$-value & OR & $95 \% \mathrm{Cl}$ & $P$-value \\
\hline $\mathrm{BMI}^{\mathrm{b}}$ & 60.960 & $\begin{array}{c}2.784, \\
1334.723\end{array}$ & $.009^{\mathrm{d}}$ & 8.685 & $.550,137.236$ & .125 & 1.012 & $.002,213.705$ & .599 \\
\hline $\begin{array}{l}\mathrm{BMI} \geq 25 \\
\mathrm{~kg} / \mathrm{m}^{2}\end{array}$ & 2.407 & $.941,6.156$ & .067 & 1.719 & $.623,4.746$ & .296 & - & - & - \\
\hline Fat mass $\%^{a}$ & 1.023 & $.973,1.076$ & .366 & 1.010 & $.960,1.063$ & .697 & 1.006 & $.935,1.083$ & .868 \\
\hline Waist $^{b}$ & .223 & $.006,7.968$ & .411 & 98.811 & $\begin{array}{c}1.697 \\
5755.086\end{array}$ & $.027^{d}$ & 65.078 & $\begin{array}{c}1.490 \\
2842.157\end{array}$ & $.030^{d}$ \\
\hline $\begin{array}{l}\text { CD4 cell } \\
\text { count }^{\mathrm{C}}\end{array}$ & .971 & $.881,1.071$ & .560 & .976 & $.874,1.090$ & .976 & .909 & $.786,1.052$ & .201 \\
\hline CD4\% & .949 & $.902, .998$ & $.042^{d}$ & .990 & $.937,1.047$ & .732 & 1.066 & $.965,1.179$ & .209 \\
\hline $\begin{array}{l}\text { HIV viral } \\
\text { load }^{b}\end{array}$ & 1.289 & $.851,1.951$ & .231 & 1.231 & $.785,1.999$ & .400 & 1.100 & .630 & \\
\hline $\begin{array}{l}\text { HIV viral load } \\
\geq 4 \log 10 \\
\text { copies } / \mathrm{mL}\end{array}$ & 1.568 & $.732,3.359$ & .247 & 1.681 & $.652,4.334$ & .282 & - & - & - \\
\hline $\begin{array}{l}\text { CD8 cell } \\
\text { count }^{\mathrm{C}}\end{array}$ & 1.030 & $.984,1.078$ & .207 & .993 & $.935,1.054$ & .811 & .906 & $.831, .988$ & $.025^{d}$ \\
\hline CD8\% & 1.023 & $.988,1.060$ & .203 & 1.010 & $.970,1.052$ & .633 & .933 & $.852,1.022$ & .137 \\
\hline $\begin{array}{l}\text { CD4/CD8 } \\
\text { Ratio }\end{array}$ & .292 & $.063,1.363$ & .117 & .621 & $.102,3.787$ & .605 & 3.544 & $.142,88.638$ & .441 \\
\hline
\end{tabular}

${ }^{*}$ Models adjusted for age, gender, smoking, and fat mass percentage

${ }^{a}$ Model adjusted for age, gender, and smoking

${ }^{\mathrm{b}}$ Log transformed

'Square root transformed

${ }^{\mathrm{d}}$ Statistically significant, $P<.05$ 
Table 11: Logistic Regression at Baseline, 18 Months, and the Change Over 18 Months by Leptin Groups (< and $\geq$ Median)*

\begin{tabular}{|c|c|c|c|c|c|c|c|c|c|}
\hline & \multicolumn{3}{|c|}{ Baseline } & \multicolumn{3}{|c|}{18 Months } & \multicolumn{3}{|c|}{ Change Over 18 Months } \\
\hline Variable & OR & $95 \% \mathrm{Cl}$ & $P$-value & OR & $95 \% \mathrm{Cl}$ & $P$-value & OR & $95 \% \mathrm{Cl}$ & $P$-value \\
\hline $\mathrm{BMI}$ & 2.073 & $1.194,3.601$ & $.010^{\mathrm{d}}$ & 1.554 & $\begin{array}{l}1.125 \\
2.146\end{array}$ & $.008^{\mathrm{d}}$ & 1.438 & $.819,2.524$ & .206 \\
\hline $\begin{array}{l}\mathrm{BMI} \geq 25 \\
\mathrm{~kg} / \mathrm{m}^{2}\end{array}$ & 58.572 & $\begin{array}{c}2.187 \\
1568.688\end{array}$ & $.015^{\mathrm{d}}$ & 79.634 & $\begin{array}{c}4.607 \\
1376.659\end{array}$ & $.003^{d}$ & - & - & - \\
\hline Fat mass $\%^{a}$ & 1.580 & $1.214,2.055$ & $.001^{d}$ & 1.231 & $\begin{array}{l}1.070 \\
1.416\end{array}$ & $.004^{\mathrm{d}}$ & .985 & $.887,1.093$ & .775 \\
\hline Waist & $<.001$ & $<.001,<.001$ & .998 & 1.267 & $\begin{array}{l}1.016 \\
1.580\end{array}$ & $.036^{\mathrm{d}}$ & .967 & $.000,-$ & 1.000 \\
\hline $\begin{array}{l}\text { CD4 cell } \\
\text { count }^{\text {b }}\end{array}$ & 1.074 & $.833,1.385$ & .581 & 1.168 & $.864,1.581$ & .313 & 1.279 & $.837,1.956$ & .256 \\
\hline CD4\% & 1.022 & $.902,1.157$ & .737 & 1.110 & $.971,1.270$ & .127 & 1.456 & $1.025,2.069$ & $.036^{\mathrm{d}}$ \\
\hline HIV viral load ${ }^{c}$ & .654 & $.231,1.850$ & .424 & .615 & $.209,1.812$ & .378 & .855 & $.186,3.928$ & .840 \\
\hline $\begin{array}{l}\text { HIV viral load } \\
\geq 4 \log 10 \\
\text { copies } / \mathrm{mL}\end{array}$ & .308 & $.039,2.408$ & .261 & .180 & $.018,1.816$ & .146 & - & - & - \\
\hline $\begin{array}{l}\text { CD8 cell } \\
\text { count }^{\mathrm{b}}\end{array}$ & 1.013 & $.878,1.169$ & .861 & .960 & $.848,1.088$ & .522 & .872 & $.698,1.089$ & .228 \\
\hline CD8\% & .982 & $.913,1.057$ & .628 & .961 & $.886,1.042$ & .338 & .867 & $.709,1.061$ & .165 \\
\hline $\begin{array}{l}\text { CD4/CD8 } \\
\text { Ratio }\end{array}$ & 5.405 & $\begin{array}{c}.124 \\
235.292\end{array}$ & .381 & 73.701 & $\begin{array}{c}.393 \\
13808.169\end{array}$ & .107 & 133.567 & $\begin{array}{c}.116 \\
154108.571\end{array}$ & .174 \\
\hline
\end{tabular}

*Models adjusted for age, smoking, and fat mass percentage

a Model adjusted for age and smoking

b Square root transformed

¿'og transformed

${ }^{d}$ Statistically significant, $P<.05$ 
Table 12: Logistic Regression at Baseline, 18 Months, and the Change Over 18 Months by LPS Groups (< and $\geq$ Median)*

\begin{tabular}{|c|c|c|c|c|c|c|c|c|c|}
\hline & \multicolumn{3}{|c|}{ Baseline } & \multicolumn{3}{|c|}{18 Months } & \multicolumn{3}{|c|}{ Change Over 18 Months } \\
\hline Variable & OR & $95 \% \mathrm{Cl}$ & $P$-value & OR & $95 \% \mathrm{Cl}$ & $P$-value & OR & $95 \% \mathrm{Cl}$ & $P$-value \\
\hline BMI & .790 & $.630, .990$ & $.041^{\mathrm{d}}$ & .799 & $.655, .976$ & $.028^{\mathrm{d}}$ & .875 & $.603,1.270$ & .482 \\
\hline $\begin{array}{l}\mathrm{BMI} \geq 25 \\
\mathrm{~kg} / \mathrm{m}^{2}\end{array}$ & .035 & $.004, .283$ & $.002^{d}$ & .321 & $.076,1.351$ & .121 & - & - & - \\
\hline Fat mass $\%^{a}$ & .852 & $.757, .958$ & $.007^{\mathrm{d}}$ & .932 & $.854,1.017$ & .113 & 1.046 & $.944,1.158$ & .391 \\
\hline Waist & .727 & $.446,1.187$ & .203 & .907 & $.778,1.056$ & .209 & .795 & $.555,1.140$ & .212 \\
\hline $\begin{array}{l}\text { CD4 cell } \\
\text { count }^{b}\end{array}$ & .915 & $.763,1.098$ & .339 & .915 & $.763,1.098$ & .339 & 1.092 & $.825,1.444$ & .538 \\
\hline CD4\% & .971 & $.888,1.061$ & .971 & .942 & $.861,1.029$ & .185 & .905 & $.784,1.045$ & .173 \\
\hline HIV viral load $^{\circ}$ & 2.608 & $1.111,6.124$ & $.028^{\mathrm{d}}$ & 1.691 & $.782,3.656$ & .182 & .637 & $.247,1.638$ & .349 \\
\hline $\begin{array}{l}\text { HIV viral load } \\
\geq 4 \log 10 \\
\text { copies } / m L\end{array}$ & 8.005 & $\begin{array}{c}1.762 \\
36.357\end{array}$ & $.007^{d}$ & 3.776 & $.959,14.869$ & .057 & - & - & - \\
\hline $\begin{array}{l}\text { CD8 cell } \\
\text { count }^{\mathrm{b}}\end{array}$ & 1.003 & $.925,1.087$ & .941 & 1.038 & $.956,1.126$ & .376 & 1.124 & $.982,1.266$ & .089 \\
\hline CD8\% & 1.025 & $.972,1.081$ & .362 & 1.038 & $.977,1.103$ & .228 & 1.061 & $.941,1.197$ & .330 \\
\hline $\begin{array}{l}\text { CD4/CD8 } \\
\text { Ratio }\end{array}$ & .630 & $.051,7.857$ & .720 & .120 & $.005,2.860$ & .190 & .032 & $.000,3.912$ & .161 \\
\hline
\end{tabular}

*Models adjusted for age, gender, smoking, and fat mass percentage

${ }^{a}$ Model adjusted for age, gender, and smoking

bquare root transformed

'Log transformed

${ }^{\mathrm{d}}$ Statistically significant, $P<.05$ 


\section{References}

1. Salazar-Gonzalez JF, Martinez-Maza O, Nishanian P, et al. Increased immune activation precedes the inflection point of CD4 T cells and the increased serum virus load in human immunodeficiency virus infection. J Infect Dis 1998;178:423430.

2. Giorgi JV, Hultin LE, McKeating JA, et al. Shorter survival in advanced human immunodeficiency virus type 1 infection is more closely associated with $\mathrm{T}$ lymphocyte activation than with plasma virus burden or virus chemokine coreceptor usage. J Infect Dis 1999;179:859-870.

3. Hunt PW, Brenchley J, Sinclair E, McCune JM, Roland M, Page-Shafer K, Hsue $\mathrm{P}$, Emu B, Krone M, Lampiris $\mathrm{H}$, et al. Relationship between $\mathrm{T}$ cell activation and CD4+ T cell count in HIV-seropositive individuals with undetectable plasma HIV RNA levels in the absence of therapy. J Infect Dis 2008;197:126-133.

4. De Lorenzo F, Collot-Teixeira S, Boffito M, Feher M, Gazzard B, McGregor JL. Metabolic-inflammatory changes, and accelerated atherosclerosis in HIV patients: rationale for preventative measures. Curr Med Chem 2008; 15:29912999.

5. Trøseid M, Manner IW, Pedersen KK, Haissman JM, Kvale D, Nielsen SD. Microbial translocation and cardiometabolic risk factors in HIV infection. AIDS Res Hum Retroviruses 2014; 30:514-522.

6. Ipp $\mathrm{H}$, Zemlin A. The paradox of the immune response in HIV infection: when inflammation becomes harmful. Clin Chim Acta 2013;416:96-99.

7. Theofilopoulos AN,Baccala R, Beutler B,Kono DH.Type I interferons (alpha/beta) in immunity and autoimmunity. Annu Rev Immunol 2005;23:307-336.

8. Douek DC, Picker LJ, Koup RA. T cell dynamics in HIV-1 infection 14. Annu Rev Immunol 2003;21:265-304.

9. Alimonti JB, Ball TB, Fowke KR. Mechanisms of CD4+ T lymphocyte cell death in human immunodeficiency virus and AIDS. J Gen Virol 2003;84:1649-1661.

10. Heilbronn LK, Campbell LV. Adipose tissue macrophages, low grade inflammation and insulin resistance in human obesity. Curr Pharm Des 2008;14:1225-1230.

11. Popkin BM, Adair LS, Ng SW. Global nutrition transition and the pandemic of obesity In developing countries. Nutr Rev 2012;70:3-21.

12. UNAIDS. Regional Fact Sheet 2012: Sub-Saharan Africa. Available at: http://www.unaids.org/sites/default/files/en/media/unaids/contentassets/documen ts/epidemiology/2012/gr2012/2012 FS regional ssa en.pdf. Accessed on January 12, 2015. 
13. Pepys MB. The acute phase response and C-reactive protein. In: Weatherall DJ, Ledingham JGG, Warrell DA, eds. Oxford Textbook of Medicine. 2nd ed. Oxford, UK: Oxford University Press; 1995:1527-1533.

14. Pitsavos C, Panagiotakos DB, Tzima N, et al. Diet, exercise, and C-reactive protein levels in people with abdominal obesity: the ATTICA epidemiological study. Angiology 2007;58:225-233.

15. Myers GL, Rifai N, Tracy RP, et al. CDC/AHA Workshop on Markers of Inflammation and Cardiovascular Disease: application to clinical and public health practice: report from the laboratory science discussion group. Circulation. 2004;110:e545-e549.

16. Ramana KV, Sabitha V, Rao R. A Study of Alternate Biomarkers in HIV Disease in Resource Poor Settings in Highly Active Antiretroviral Therapy (HAART) Era. J Clin Diagn Res 2013;7:1332-1335. doi: 10.7860/JCDR/2013/5306.3138.

17. Boulware DR, Hullsiek KH, Puronen CE, et al. Higher levels of CRP, D-dimer, IL-6, and hyaluronic acid before initiation of antiretroviral therapy (ART) are associated with increased risk of AIDS or death. J Infect Dis 2011;203:1637-46. doi: 10.1093/infdis/jir134.

18. Fantuzzi G, Faggioni R. Leptin in the regulation of immunity, inflammation and hematopoiesis. J Leukoc Biol 2000;68:437-446.

19. Martin-Romero C, Santos-Alvarez J, Goberna R, Sanchez-Margalet V. Human leptin enhances activation and proliferation of human circulating $\mathrm{T}$ lymphocytes. Cell Immunol 2000;199:15-24.

20. Considine RV, Sinha MK, Heiman ML, et al: Serum immunoreactive-leptin concentrations in normal-weight and obese humans. N Engl J Med 1996;334:292-295.

21. Azzoni L, Crowther NJ, Firnhaber C, et al. Association between HIV replication and serum leptin levels: an observational study of a cohort of HIV-1-infected South African women. J Int AIDS Soc 2010;13:33. doi: 10.1186/1758-2652-1333.

22. Sandler NG, Douek DC. Microbial translocation in HIV infection: causes, consequences and treatment opportunities. Nat Rev Microbiol 2012;10:655-666.

23. Opal SM. The host response to endotoxin, antilipopolysacchride strategies, and the management of severe sepsis. Int J Med Microbiol 2007;297:365-377.

24. Hunt PW, Brenchley J, Sinclair E, et al., Relationships between T cell activation and CD4 T cell count in HIV-seropositive individuals with undetectable plasma HIV RNA levels in the absence of therapy. J Infect Dis 2008;197:126-133. 
25. Cani PD, Amar J, Iglesias MA, et al. Metabolic endotoxemia initiates obesity and insulin resistance. Diabetes 2007;56:1761-1772.

26. Jiang W, Lederman MM, Hunt $P$, et al. Plasma levels of bacterial DNA correlate with immune activation and the magnitude of immune restoration in persons with antiretroviral-treated HIV infection. J Infect Dis 2009;199:1177-1185.

27. Brenchley JM, Price DA, Schacker TW, et al. Microbial translocation is a cause of systemic immune activation in chronic HIV infection. Nat Med 2006;12:13651371.

28. Marchetti G, Cozzi-Lepri A, Merlini E, et al. Microbial translocation predicts disease progression of HIV-infected antiretroviral-naive patients with high CD4+ cell count. AIDS 2011;25:1385-1394.

29. Rauchhaus M, Coats AJS, Anker S. The endotoxin-lipoprotein hypothesis. Lancet 2000;356:930-933.

30. Baum MK, Campa A, Lai S, et al. Effect of micronutrient supplementation on disease progression in asymptomatic, antiretroviral-naive, HIV-infected adults in Botswana: a randomized clinical trial. JAMA 2013;310:2154-2163.

31. Murnane PM, Hughes JP, Celum C, et al Using plasma viral load to guide antiretroviral therapy initiation to prevent HIV-1 transmission. PLos One 2012; 7:e51192.

32. Phillips A, Pezzotti P. Short-term risk of AIDS according to current CD4 cell count and viral load in antiretroviral drug-naïve individuals those treated in the monotherapy era. AIDS 2004;15:51-58.

33. Sopori ML, Kozak W. Immunomodulatory effects of cigarette smokers. J Neuroimmunol 1998;83:148-146.

34. De Heens GL, van der Velden U, Loos BG. Cigarette smoking enhances T cell activation and a Th2 immune response; an aspect of the pathophysiology in periodontal disease. Cytokine 2009;47:157-161.

35. Ledwaba L, Tavel JA, Khabo P, et al. Pre-ART levels of inflammation and coagulation markers are strong predictors of death in a South African cohort with advanced HIV disease. PLoS One 2012;7:e24243.

36. Chaudhary M, Kashyap B, Gautam H, Saini S, Bhalla P. Role of C-Reactive Protein in HIV Infection: A Pilot Study. Viral Immun 2008;21:263-266.

37. Lau B, Sharrett AR, Kingsley LA, Post W, Palella FJ, Visscher B, Gange SJ. CReactive Protein Is a Marker for Human Immunodeficiency Virus Disease Progression. Arch Intern Med 2006;166:64-70. 
38. Taylor JM, Fahey JL, Detels R, Giorgi JV. CD4 percentage, CD4 number, and CD4:CD8 ratio in HIV infection: which to choose and how to use. J Acquir Immune Defic Syndr 1989;2:114-124.

39. Burcham J, Marmor M, Dubin N, et al. CD4\% is the best predictor of development of AIDS in a cohort of HIV-infected homosexual men. AIDS 1991; 5:365-372.

40. Ravimohan S, Tamuhla N, Steenhoff AP, et al. Early immunologic failure is associated with early mortality among advanced HIV-infected adults initiating antiretroviral therapy with active tuberculosis. J Infect Dis 2013;208:1784-1793. doi: 10.1093/infdis/jit368.

41. McDonald B, Moyo S, Gabaitiri L, et al. Persistently elevated serum interleukin-6 predicts mortality among adults receiving combination antiretroviral therapy in Botswana: results from a clinical trial. AIDS Res Hum Retroviruses 2013;29:993999. doi: 10.1089/AID.2012.0309.

42. Martin-Romero C, Santos-Alvarez J, Goberna R, Sanchez-Margalet V. Human leptin enhances activation and proliferation of human circulating $T$ lymphocytes. Cell Immunol 2000;199:15-24.

43. Prabha C, Karthic S, Das SD, Swaminathan S, Subramaniam S, Sukumar B. Impact of Tuberculosis on Serum Leptin Levels in Patients with HIV infection. Horm Res 2005;63:228-233.

44. Onyemelukwe GC, Ogoina D, Bakari AG. Serum Leptin Levels in Antitretroviral Therapy Naïve HIV-1 Infected Patients in Zaria, Nigeria. Int J Endocrinol Metab 2009;3:162-169.

45. Redd AD, Eaton KP, Kong X, et al. C-reactive protein levels increase during HIV1 disease progression in Rakai, Uganda, despite the absence of microbial translocation. J Acquir Immune Defic Syndr 2010;54:556-559.

46. Lester RT, Yao XD, Ball TB, McKinnon LR, Omange WR, Kaul R, Wachihi C, Jaoko W, Rosenthal KL, Plummer FA. HIV-1 RNA dysregulates the natural TLR response to subclinical endotoxemia in Kenyan female sex-workers. PLoS One 2009;4:e5644. doi: 10.1371/journal.pone.0005644.

47. Timmons T, Shen C, Aldrovandi G, et al. Microbial translocation and metabolic and body composition measures in treated and untreated HIV infection. AIDS Res Hum Retroviruses 2014;30:272-7. doi: 10.1089/AID.2013.0162.

48. Lien E, Aukrust P, Sundan A, Müller F, Frøland SS, Espevik T. Elevated levels of serum-soluble CD14 in human immunodeficiency virus type 1 (HIV-1) infection: correlation to disease progression and clinical events. Blood 1998;92:2084-2092.

49. Zhang $\mathrm{C}$, Zhang M, Wang S, et al. Interactions between gut microbiota, host genetics and diet relevant to development of metabolic syndromes in mice. ISME J 2010;4:232-241. doi: 10.1038/ismej.2009.112. 
50. Cani PD, Amar J, Iglesias MA et al. Metabolic endotoxemia initiates obesity and insulin resistance. Diabetes 2007;56:1761-1772.

51. Lamaon-Gava S, Wilson PWF, Schaefer EJ. Impact of body mass index on coronary heart disease risk factors in men and women: The Framingham OffSpring Study. Arterioscler Throm Vasc Biol 1996;16:1509-1515.

52. Denke MA, Sempos CT, Grundy SM. Excess body weight. An underrrecgonized contributor to high blood cholesterol levels in white American men. Arch Intern Med 1993;153:1040-1103.

53. Pérez-Matute P, Pérez-Martínez L, Blanco JR, et al. Multiple frequency bioimpedance is an adequate tool to assess total and regional fat mass in HIVpositive patients but not to diagnose HIV-associated lipoatrophy: a pilot study. J Int AIDS Soc 2013;16:18609. doi: 10.7448/IAS.16.1.18609.

54. Bioelectrical impedance analysis in body composition measurement: National Institutes of Health Technology Assessment Conference Statement. Am J Clin Nutr 1996;64:524S-532S. 


\section{CHAPTER VI: SUMMARY AND CONCLUSIONS}

This study investigated the obesity paradox in HIV+ ART naïve adults who were in early stage of HIV disease in Botswana. The impact of obesity on HIV disease progression over time was explored. An obesity paradox has been documented in many conditions including HIV, where those who are obese may have a survival advantage or improved disease outcomes. ${ }^{1}$ The genetic propensity for being overweight or obese was examined using SNPs of the FTO gene, which is reported to be most associated with BMI, and its association to HIV disease progression. In addition, inflammatory markers and their relationship to body composition and HIV disease progression were investigated.

Studies on HIV and obesity are mainly conducted in settings where the patients are treated with ART, which may confound some of the findings and interpretations, as ART has been associated with lipodystrophy and obesity. ${ }^{2}$ Rising rates of obesity have been documented in countries with limited resources; ${ }^{3}$ however, studies conducted in African settings on the relationship between HIV and obesity are lacking. Studies conducted to investigate obesity and its effect on HIV disease progression have so far been inconclusive, with some studies reporting an association and others reporting no association between CD4 cell counts and obesity. ${ }^{1,4}$ Studies on the relationship between BMI and body composition on HIV disease progression are needed to reveal possible mechanisms for the obesity paradox in HIV. The examination of such interrelationships is important for translation of results into clinically relevant recommendations for people living with HIV.

Our results demonstrated a protective effect of BMI and fat mass in delaying the time to the first AIDS defining condition in HIV+ ART naïve adults in Botswana during 18 months of follow-up. Higher BMI was also associated with a higher CD4\%, another 
marker of HIV disease progression over 18 months. In addition, higher fat mass was also associated with the combined outcome of CD4 cell count $\leq 250 / \mu \mathrm{L}$ and AIDS defining conditions. Survival analysis showed a positive trend with the outcome of a decline in the CD4 cell count of $25 \%$ or greater and association with fat mass and negative association with lean body mass. Findings from these analyses indicate that higher fat may provide protection from advanced HIV disease. The fat stores would have provided the extra energy needed to maintain the innate immune system responding to protect against opportunistic infections and delaying wasting. Extra available energy for use in times of emergency during the HIV disease may reduce the use of protein for energy $^{8}$ and also assist to conserve the immune system, especially the innate immunity that is not directly affected by the infection. ${ }^{9,10}$

This study provides preliminary data on the genetic association between FTO SNPs on the genetic risk of being overweight/obese and HIV disease progression in HIV+ adults in Botswana. There were no significant findings between the FTO SNPs and markers of HIV disease progression; however, a trend between the risk allele for rs8050136 was protective of having higher HIV viral load. The variant rs17817449 had a significant association with BMI, showing a greater odds of having higher BMI when the risk allele was present. The risk alleles for rs1121980, rs8050136, and rs17817449 were associated with fat mass and lean mass. A higher percentage of fat mass and lower lean body mass were associated with these risk alleles compared to homozygosity for the non-risk allele. Although the exact mechanism for the effect of FTO on weight is unknown, it is hypothesized that it may affect food intake and energy expenditure. ${ }^{11}$ FTO is highly expressed in the hypothalamus region of the brain, where food intake is controlled. ${ }^{12,13}$ The FTO still remains the gene most consistently associated with obesity in various populations, ${ }^{14}$ but its associations have not been replicated in many African 
populations. GWAS studies in African populations are lacking, and identifying SNPs that are relevant to this population is of importance since the SNPs showing associations in European and Asian populations may be different from SNPs that will show associations in African populations.

The relationship of inflammatory markers such as C-reactive protein, leptin, and bacterial endotoxin lipopolysaccharide (LPS) with body composition and HIV disease progression in HIV+ asymptomatic adults not on ART in Botswana over 18 months was also evaluated. To our knowledge, no study has assessed leptin or LPS in a population from Botswana with or without HIV infection. The results from this study suggest a strong association of inflammation markers with body composition and HIV disease progression in ART naïve adult participants in Botswana. Higher levels of inflammation as measured was associated with a more progressed state of the disease. The relationships were found to be independent of body fat. Our findings support the hypotheses in the literature that high viral replication and immune activation could result in chronic inflammation that would cause lipoatrophy, therefore, lowering leptin levels. ${ }^{15}$ LPS levels above the median were associated with higher viral load and those with LPS levels $\geq$ the median were 8 times more likely to have viral load $>4 \log _{10}$ copies $/ \mathrm{mL}$ or 10,000 copies/mL. In addition, LPS was also inversely associated with measures of body composition, therefore being overweight or obese was protective of having higher levels of LPS. The endotoxin lipoprotein hypothesis or theory may provide a possible explanation for the lower levels of LPS observed in those with higher BMI. Higher circulating lipoproteins may modulate inflammation by binding to lipopolyssachrides and reduce their effect on release of proinflammatory cytokines. ${ }^{16}$

Current study demonstrated that an obesity paradox may be present in early HIV infection. We investigated and suggest several mechanisms for this paradox. Fat 
accumulation was found to be protective against further HIV disease progression in HIV+ adults who were early in the disease state and ART naïve. Higher levels of leptin and lower levels of LPS were associated with being overweight/obese and higher amounts of body fat mass percentage. Concurrently, lower leptin and higher LPS levels had significant relationships to higher HIV viral load, a marker of HIV disease progression. Additionally, a trend association was demonstrated with one of the FTO SNPs and HIV viral load. The risk allele was associated with lower HIV viral load, therefore having a protective effect. Establishment of mechanisms for this paradox are needed in order to allow for translation of results into meaningful clinical recommendations and care guidelines for resource limited settings. 
Table 1: Study Hypotheses and Results

\begin{tabular}{|c|c|c|}
\hline Hypothesis \# & Hypothesis & Study Results \\
\hline $1 a$ & $\begin{array}{l}\text { (Primary outcome) The overweight/obese group will } \\
\text { present less clinically significant CD4 cell count } \\
\text { decline from Baseline }(\geq 25 \%) \text { over } 18 \text { months than } \\
\text { the normal weight group. }\end{array}$ & $\begin{array}{l}\text { There were no significant differences between BMI } \\
\text { groups in the main outcome } \geq 25 \% \text { decline in } \mathrm{CD} 4 \text { cell } \\
\text { count over } 18 \text { months (HR=.744; } 95 \% \mathrm{Cl}=.489,1.131 \text {; } \\
P=.166 \text { ) after controlling for age, gender, marital status } \\
\text { children (yes/no), baseline CD4 cell count and baseline } \\
\text { HIV viral load. }\end{array}$ \\
\hline $1 b$ & $\begin{array}{l}\text { The overweight/obese will have significantly lower } \\
\text { levels of HIV viral load over } 18 \text { months than the } \\
\text { normal weight group. }\end{array}$ & $\begin{array}{l}\text { BMI groups at baseline, } 18 \text { months and the change } \\
\text { over } 18 \text { months were not statistically associated with } \\
\text { HIV viral load. }\end{array}$ \\
\hline $1 \mathrm{c}$ & $\begin{array}{l}\text { Significantly less AIDS defining conditions will occur } \\
\text { over } 18 \text { months in the overweight/obese group } \\
\text { compared to the normal weight group. }\end{array}$ & $\begin{array}{l}\text { There were no significant differences between BMI } \\
\text { groups in the outcome of AIDS defining conditions } \\
\text { (HR=.500; } 95 \% \mathrm{Cl}=.047,4.465 ; \mathrm{P}=.500) \text { after } \\
\text { controlling for age, gender, marital status, children } \\
\text { (yes/no), baseline CD4 cell count and baseline HIV viral } \\
\text { load. However, continuous BMI was associated with } \\
\text { AIDS defining conditions (HR=.218, } 95 \% \mathrm{Cl}=.068, .701 \text {, } \\
P=.011 \text { ). }\end{array}$ \\
\hline $2 a$ & $\begin{array}{l}\text { The FTO gene SNPs will be associated with being } \\
\text { overweight/obese. }\end{array}$ & $\begin{array}{l}\text { The FTO SNP rs } 17817449 \text { was associated with BMI } \\
(\mathrm{OR}=1.082 ; 95 \% \mathrm{Cl}=1.001,1.169 ; P=.047) \text {. }\end{array}$ \\
\hline $2 \mathrm{~b} 1$ & $\begin{array}{l}\text { The FTO gene SNPs will be associated with } \\
\text { significantly higher CD4 cell count. }\end{array}$ & $\begin{array}{l}\text { There were no significant associations with between } \\
\text { FTO SNPs and CD4 cell count. }\end{array}$ \\
\hline $2 \mathrm{~b} 2$ & $\begin{array}{l}\text { The FTO gene SNPs will be associated with } \\
\text { significantly lower HIV viral load. }\end{array}$ & $\begin{array}{l}\text { None of the FTO SNPs were significantly associated } \\
\text { with HIV viral load. However, there was a trend } \\
\text { towards significance with rs } 8050136 \text { and HIV viral load } \\
\text { in a dominant model (OR=.705; } 95 \% \mathrm{Cl}=.481,1.035 \text {; } \\
P=.074 \text { ) after controlling for age, gender, tribes, total } \\
\text { dietary kcal, and activity. }\end{array}$ \\
\hline $2 b 3$ & $\begin{array}{l}\text { The FTO gene SNPs will be associated with } \\
\text { significantly less AIDS-defining conditions. }\end{array}$ & $\begin{array}{l}\text { There were no significant associations between FTO } \\
\text { SNPs and AIDS-defining conditions. }\end{array}$ \\
\hline $3 a 1$ & Higher levels of inflammatory markers will be & There were no significant associations with between \\
\hline
\end{tabular}




\begin{tabular}{|c|c|c|}
\hline & associated with lower levels of CD4 cell count. & inflammatory markers and CD4 cell count. \\
\hline $3 \mathrm{a} 2$ & $\begin{array}{l}\text { Higher levels of inflammatory markers will be } \\
\text { associated with higher HIV viral load. }\end{array}$ & $\begin{array}{l}\text { Leptin was associated with } \mathrm{HIV} \text { viral load }>4 \log _{10} \\
\text { copies/mL (OR=-.305; } 95 \% \mathrm{Cl}=-.579,-.031 ; P=.030 \text { ) at } \\
\text { baseline. LPS above the median was associated with } \\
\text { HIV viral load (OR=2.608, } 95 \% \mathrm{Cl}=1.111,6.124 \text {, } \\
P=.028) \text { and } \mathrm{HIV} \text { viral load }>4 \log _{10} \text { copies } / \mathrm{mL} \text { (OR=- } \\
8.005 ; 95 \% \mathrm{Cl}=1.762,36.357 ; P=.007) \text { at baseline and } \\
\text { HIV viral load }>4 \text { log } 10 \text { copies } / \mathrm{mL}(\mathrm{OR}=-3.776 ; 95 \% \mathrm{Cl}= \\
.959,14.869 ; \mathrm{P}=.057) \text { at } 18 \text { months. }\end{array}$ \\
\hline 3а3 & $\begin{array}{l}\text { Higher levels of inflammatory markers will be } \\
\text { associated with greater AIDS-defining conditions. }\end{array}$ & $\begin{array}{l}\text { There were no significant associations with between } \\
\text { inflammatory markers and AIDS-defining conditions. }\end{array}$ \\
\hline
\end{tabular}




\section{References}

1. McAuley PA, Blair SN. Obesity paradoxes. J Sports Sci 2011;29:773-782.

2. Carr A, Samaras K, Burton S, et al. A syndrome of peripheral lipodystrophy, hyperlipidaemia and insulin resistance in patients receiving HIV protease inhibitors. AIDS 1998;12:F51-F58.

3. Gersh BJ, Sliwa K, Mayosi BM, Yusuf S. Novel therapeutic concepts: the epidemic of cardiovascular disease in the developing world: global implications. Eur Heart J 2010;31:642-648. doi: 10.1093/eurheartj/ehq030.

4. Adeyemi OM, Vibhakar S, Evans AT. Obesity and lymphocyte subsets in virologically suppressed HIV-infected patients. Metabolism 2009;58:1285-1287.

5. Jones CY, Hogan JW, Snyder B, et al. Overweight and human immunodeficiency virus (HIV) progression in women: associations HIV disease progression and changes in body mass index in women in the HIV epidemiology research study cohort. Clin Infect Dis 2003;37:S69-80.

6. Shuter J, Chang CJ, Klein RS. Prevalence and predictive value of overweight in an urban HIV care clinic. J Acquir Immune Defic Syndr 2001;26:291-297.

7. Shor-Posner G, Campa A, Zhang G, et al. When obesity is desirable: a longitudinal study of the Miami HIV-1-infected drug abusers (MIDAS) cohort. J Acquir Immune Defic Syndr 2000;23:81-88.

8. Carlson MG, Snead WL, Campbell PJ. Fuel and energy metabolism in fasting humans. Am J Clin Nutr 1994;60:29-36.

9. Chandra RK. Nutrition and the immune system: an introduction. Am J Clin Nutr 1997;66:460S-463S.

10. Shor-Posner G, Campa A, Zhang G, et al. When obesity is desirable: a longitudinal study of the Miami HIV-1-infected drug abusers (MIDAS) cohort. J Acquir Immune Defic Syndr 2000;23:81-88.

11. Zhao X, Yang Y, Sun BF, Zhao YL, Yang YG. FTO and obesity: mechanisms of association. Curr Diab Rep 2014;14:486. doi: 10.1007/s11892-014-0486-0.

12. Gerken T, Girard CA, Tung YC, et al. The obesity-associated FTO gene encodes a 2-oxoglutarate-dependent nucleic acid demethylase. Science 2007 30;318:1469-1472.

13. Fredriksson R, Hägglund M, Olszewski PK, et al. The obesity gene, FTO, is of ancient origin, up-regulated during food deprivation and expressed in neurons of feeding-related nuclei of the brain. Endocrinology 2008;149(5):2062-2071.

14. Loos RJ, Bouchard C. FTO: the first gene contributing to common forms of human obesity. Obes Rev 2008;9:246-250. 
15. Azzoni L, Crowther NJ, Firnhaber C, et al. Association between HIV replication and serum leptin levels: an observational study of a cohort of HIV-1-infected South African women. J Int AIDS Soc 2010;13:33. doi: 10.1186/1758-2652-1333.

16. Rauchhaus M, Coats AJS, Anker S. The endotoxin-lipoprotein hypothesis. Lancet 2000;356:930-933. 


\section{CHAPTER VII: STRENGTHS AND LIMITATIONS}

The results from this study could be translated into clinically relevant nutrition and care recommendations for HIV+ adults who are antiretroviral (ART) naïve in limited resource settings. This is the first study to examine the effect of the genetic propensity to become overweight/obese and inflammatory markers on HIV disease progression in an $\mathrm{HIV}+$ population in Botswana early in their disease. Both inflammatory markers, leptin and LPS, have not previously been investigated in Botswana, with or without HIV. Additionally, the FTO gene has never been genotyped in an HIV -infected population and its association to HIV disease progression examined.

The strengths of this study consists of capturing and analyzing longitudinal data from HIV+ participants in Botswana, that was collected from the early asymptomatic stage through later stages with well-defined health outcomes. This type of information is lacking in African populations. Considering that most of the HIV+ cases are within sub Saharan Africa, ${ }^{1}$ more research in this area is warranted. This was also the first known study to assess the role of FTO in the obesity paradox that often occurs in HIV+ adults. Trends were noted in the relationship of some of the FTO SNPs with markers of HIV disease progression, which may suggest a role in the obesity paradox and needs further investigation in a larger cohort with adequate sample size.

\section{Sample Size}

The limitations of this study may have contributed to some of the null findings observed. The sample size was insufficient to be able to examine differences between overweight and obese groups separately. A larger sample size would have allowed for the examination of the relationship of the FTO SNPs and body mass in further stratified subgroups of overweight and obese separately. BMI in the range of underweight category was not studied since underweight individuals were excluded from participation 
in the parent study, as those ranges are strong prognostic of AIDS. ${ }^{2}$ Inadequate sample size may have also contributed to find non-significant associations between inflammatory markers and CD4 cell count. In addition, there was a predominance of women among the participants. Botswana is known to be a heterogeneous population with many ethnic groups. ${ }^{3}$ The heterogeneity present in this population may also be a limitation for this study.

\section{Study Design}

Study limitations also include a weaker study design, which was retrospective and observational. The exact time since HIV diagnosis or infection were not available; however, it was known that the participants were asymptomatic, never had a diagnosis of AIDS and did not qualify for ART. The majority were referred from the clinics where they were diagnosed. This HIV population was in the early stage of the disease and its finding cannot be generalized to all HIV patients, and may be one of the reasons why we did not see a significant decline of CD4 as a main outcome. Findings from this study cannot be generalized to other HIV+ populations, including ART-treated patients, but may be used in resource limited settings were ART is being slowly rolled out.

\section{Methods}

In HIV, bioimpedance (BIA) has been shown to be an effective method for detecting fat mass; however, BIA have limitations, since its values can be influenced by body arrangement, hydration, ingestion of food and drinks, air and body temperature and exercise. ${ }^{4}$ Our BIA measurement protocol minimized the potential for variability by providing detailed instructions to the participants on their preparation for their visit, and standardizing the measurement parameters.

Selection bias may have contributed to null findings since we chose to complete leptin and LPS in a subset that had samples available at baseline and 18 months. 
Participants who had both samples were those who maintained their CD4 cell counts above the cut-off for eligibility for ART and were still followed by the parent study. Therefore, those excluded may have been rapid progressors, with different genetic makeup. Interestingly, despite these limitations, we had findings with CD4\% and CRP and leptin and LPS with viral load.

LPS measured by the Limulus amebocyte lysate ( $L A L)$ method is the most widely used method; however, it may be affected by inhibition or interference of other compounds. ${ }^{5}$ To prevent interference, dilution and heating methods were incorporated into the LPS assay methodology for this study. The LAL method for measuring LPS is currently only recommended for research purposes and not for a clinical setting.

The obesity paradox is present in the literature in a variety of diseases that include HIV. ${ }^{6}$ Controversies exist on both sides of the dispute on whether this paradox is real, a query that has implications for HIV management and public health efforts. Equipoise in the literature regarding obesity paradoxes should drive the need for more research to provide the appropriate care and advice for patients. The results from this study may be used as preliminary data for future research in this topic. 


\section{References}

1. UNAIDS. Regional Fact Sheet 2012: Sub-Saharan Africa. Available at: http://www.unaids.org/sites/default/files/en/media/unaids/contentassets/documen ts/epidemiology/2012/gr2012/2012 FS regional ssa en.pdf. Accessed on January 12, 2015.

2. Baum MK, Campa A, Lai S, et al. Effect of micronutrient supplementation on disease progression in asymptomatic, antiretroviral-naive, HIV-infected adults in Botswana: a randomized clinical trial. JAMA 2013;310:2154-2163.

3. Hjort J. Pre-colonial culture, post-colonial economic success? The Tswana and the African economic miracle. Econ Hist Rev 2010;63:688-709.

4. Bioelectrical impedance analysis in body composition measurement: National Institutes of Health Technology Assessment Conference Statement. Am J Clin Nutr 1996;64:524S-532S.

5. Associates of Cape Cod I. Testing of blood samples for endotoxin. LAL Update 2006;23:1-5.

6. McAuley PA, Blair SN. Obesity paradoxes. J Sports Sci 2011;29:773-782. 


\section{CHAPTER VIII: FUTURE RESEARCH}

The results from this study demonstrated that fat may provide protection against further HIV disease progression in HIV+ adults who are early in the disease and ART naïve. Higher levels of leptin and lower levels of LPS were associated with being overweight/obese and higher amounts of body fat mass percentage. At the same time, higher leptin and lower LPS levels had significant relationships to higher HIV viral load, a marker of HIV disease progression. There was a trend association with one of the FTO SNPs and HIV viral load. However, genetic association studies generally require large sample sizes. ${ }^{1}$ It seems there is an obesity paradox present in the HIV+ ART naïve cohort we investigated. An obesity paradox is present in several diseases and conditions ${ }^{2}$ and mechanistic studies are needed in this area of obesity and HIV to establish the nature and cause for this paradox in order to develop clinical recommendations. The preliminary results from the analyses conducted with FTO SNPs, inflammatory markers, and measures of HIV disease progression will be useful to calculate sample size for future studies. Further examination of the mechanisms and best approaches for translation of findings into recommendations into care of people living with HIV are needed. 


\section{References}

1. Hong EP1, Park JW. Sample size and statistical power calculation in genetic association studies. Genomics Inform 2012;10:117-122. doi:

10.5808/GI.2012.10.2.117.

2. McAuley PA, Blair SN. Obesity paradoxes. J Sports Sci 2011;29:773 782. 
VITA

\section{SABRINA SALES MARTINEZ}

Born, Manhasset, New York

1997-2001

B.S., Dietetics and Nutrition

Florida International University

Miami, Florida

2002-2004

Graduate Research Assistant

Florida international University

Miami, Florida

2002-2005

M.S., Dietetics and Nutrition

Florida International University

Miami, Florida

2005-present

Coordinator, Research Programs

Florida International University

Miami, Florida

2010-2015

Doctoral Candidate

Florida International University

Miami, Florida

\section{PUBLICATIONS AND PRESENTATIONS}

Baum MK, Campa A, Lai S, Martinez SS, Tsalaile L, Burns P, Farahani M, Li Y, van Widenfelt E, Page JB, Bussmann H, Fawzi WW, Moyo S, Makhema J, Thior I, Essex M, Marlink R. Effect of micronutrient supplementation on disease progression in asymptomatic, antiretroviral-naive, HIV-infected adults in Botswana: a randomized clinical trial. JAMA 2013;310(20):2154-63.

Parsons M, Campa A, Lai S, Li Y, Martinez JD, Murillo J, Greer P, Martinez SS, Baum MK. Effect of GSTM1-Polymorphism on Disease Progression and Oxidative Stress in HIV Infection: Modulation by HIV/HCV Co-Infection and Alcohol Consumption. J AIDS Clin Res 2013; (9).pii:10002337.

Shin D-H, Martinez SS, Parsons M, Jayaweera DT, Campa A, Baum MK. Relationship of oxidative stress with HIV Disease Progression in HIV/HCV co-infected and HIV monoinfected adults in Miami. Int J Biosci Biochem Bioinforma 2012;2(3):217-223.

Baum MK, Sales S, Jayaweera DT, Lai S, Bradwin G, Rafie C, Page JB, Campa A. CoInfection with Hepatitis C Virus (HCV), Oxidative Stress and Antioxidant Status in HIVPositive Drug Users in Miami. HIV Med 2011;12(2):78-86. 
Baum MK, Lai S, Sales S, Page JB, Campa A. Randomized Controlled Clinical Trial of Zinc Supplementation to Prevent Immunological Failure in HIV-Positive Adults. Clin Infect Dis 2010;50(12):1653-1660.

Baum MK, Rafie C, Lai S, Sales S, Page JB, Campa A. Alcohol Use Accelerates HIV Disease Progression. AIDS Res Hum Retroviruses 2010;26(5):511-518.

Baum MK, Rafie C, Lai S, Sales S, Page B, Campa A. Crack-Cocaine Use Accelerates HIV Disease Progression in HIV+ Drug Users. J Acquir Immune Def Syndr 2009;50(1):93-99.

Baum MK, Rafie C, Sales S, Lai S, Duan R, Jayaweera DT, Page JB, Campa A. Creactive protein: a poor marker of cardiovascular disease risk in HIV+ populations with a high prevalence of elevated serum transaminases. Int J STDs AIDS 2008;19:410-413.

Baum MK, Jayaweera D, Duan R, Sales S, Lai S, Rafie C, Regev A, Page JB, Berkman, R, Campa A. Quality of Life, Symptomatology, and Healthcare Utilization in HIV/HCV Co-Infected Drug Users in Miami. J Addict Dis 2008;27(2):37-48.

Campa A, Jayaweera DT, Rafie C, Sales S, Page JB, Baum MK. "When Access to Antiretroviral for All is Not Enough. J Public Adm Manag 2007;12(3):147-159.

Baum MK, Rafie C, Lai S, Xue L, Sales S, Page JB, Berkman R, Karas L, Campa A. Coronary Heart Disease Risk Factors and Metabolic Syndrome in HIV-Positive Chronic Drug Users in Miami. Am J Infect Dis 2006;2(3):173-179.

Campa A, Yang Z, Lai S, Xue L, Phillips JC, Sales S, Page JB, Baum MK. HIV-Related Wasting in HIV-Infected Drug Users in the Era of Highly Active Antiretroviral Therapy. Clin Infect Dis 2005;41:1179-1185. 